\title{
Pilot-project meting bestemming schoolverlaters IVBO en VSO
}

Citation for published version (APA):

Ramaekers, G. W. M., \& van de Loo, P. J. E. (1996). Pilot-project meting bestemming schoolverlaters IVBO en VSO. Researchcentrum voor Onderwijs en Arbeidsmarkt, Faculteit der Economische Wetenschappen. ROA Reports No. 12 https://doi.org/10.26481/umarep.1996012

Document status and date:

Published: 01/01/1996

DOI:

10.26481/umarep.1996012

Document Version:

Publisher's PDF, also known as Version of record

\section{Please check the document version of this publication:}

- A submitted manuscript is the version of the article upon submission and before peer-review. There can be important differences between the submitted version and the official published version of record.

People interested in the research are advised to contact the author for the final version of the publication, or visit the DOI to the publisher's website.

- The final author version and the galley proof are versions of the publication after peer review.

- The final published version features the final layout of the paper including the volume, issue and page numbers.

Link to publication

\footnotetext{
General rights rights.

- You may freely distribute the URL identifying the publication in the public portal. please follow below link for the End User Agreement:

www.umlib.nl/taverne-license

Take down policy

If you believe that this document breaches copyright please contact us at:

repository@maastrichtuniversity.nl

providing details and we will investigate your claim.
}

Copyright and moral rights for the publications made accessible in the public portal are retained by the authors and/or other copyright owners and it is a condition of accessing publications that users recognise and abide by the legal requirements associated with these

- Users may download and print one copy of any publication from the public portal for the purpose of private study or research.

- You may not further distribute the material or use it for any profit-making activity or commercial gain

If the publication is distributed under the terms of Article $25 \mathrm{fa}$ of the Dutch Copyright Act, indicated by the "Taverne" license above, 


\section{Pilot-project meting bestemming schoolverlaters IVBO en VSO}

ROA-R-1996/12

G.W.M. Ramaekers

P.J.E. van de Loo

Researchcentrum voor Onderwijs en Arbeidsmarkt

Faculteit der Economische Wetenschappen en Bedrijfskunde Universiteit Maastricht

Maastricht, november 1996 
ISBN 90-5321-192-6 


\section{Inhoud}

Bladzijde

Voorwoord $\quad$ i

1 Inleiding 1

1.1 Aanleiding voor het pilot-project 1

1.2 Opzet van het pilot-project 1

1.3 Leeswijzer 3

Deel 1 Vooronderzoek meting bestemming schoolverlaters IVBO en VSO

2 Individueel voorbereidend beroepsonderwijs $\quad 7$

2.1 Positie IVBO $\quad 7$

2.2 Schoolverlaters van het IVBO in de RUBS-enquête 8

2.3 Randvoorwaarden voor meting van de bestemming 18

3 Voortgezet speciaal onderwijs 33

3.1 Afbakening onderzoekspopulatie 33

3.2 Meting van de eerste bestemming 37

3.3 Meting van de latere bestemming $\quad 39$

4 Voorstel voor proefmeting 43

4.1 IVBO 43

4.2 VSO 46

Deel 2 Proefmeting bestemming schoolverlaters IVBO

5 Opzet van de proefmeting 51

6 Representativiteit en betrouwbaarheid van de onderzoekinstrumenten 53

6.1 Dataverzameling en respons 53

6.2 Representativiteit $\quad 54$

6.3 Betrouwbaarheid van het meetinstrument 57

6.4 Betrouwbaarheid en vraagstelling 58

6.5 Respons per vraag $\quad 61$

6.6 Consistentie bij de beantwoording 64

$\begin{array}{ll}7 \text { Arbeidsmarktpositie van de respondenten } & 67\end{array}$

7.1 Samenstelling onderzoekspopulatie $\quad 67$

$\begin{array}{ll}7.2 \text { Kans op werk } & 69\end{array}$

$\begin{array}{ll}7.3 \text { Vervolgonderwijs na schoolverlaten } & 69\end{array}$

$\begin{array}{ll}7.4 \text { Werken na schoolverlaten } & 70\end{array}$ 
Literatuur

Bijlage 1 Lijst van gesprekspartners

Bijlage 2 Gesprekspunten interviews met schooldecanen IVBO

Bijlage 3 Invulanalyse vragenlijsten RUBS 1993

Bijlage 4 RUBS-vragenlijst 1993

Bijlage 5 Definitie van de term 'schoolverlater' 97

Bijlage 6 Schoolformulier proefmeting bestemming IVBO'ers 99

Bijlage 7 Vragenlijst schriftelijke proefmeting bestemming IVBO'ers 


\section{Voorwoord}

In opdracht van het Ministerie van Onderwijs, Cultuur en Wetenschappen heeft het Researchcentrum voor Onderwijs en Arbeidsmarkt (ROA) een pilotonderzoek verricht naar de meest geschikte wijze om de bestemming van schoolverlaters van het individueel voorbereidend beroepsonderwijs (IVBO) en het voortgezet speciaal onderwijs (VSO) te meten. Het pilotonderzoek is in twee fasen uitgevoerd. In het vooronderzoek (1993/1994) is door het ROA een nadere uitwerking gemaakt van de onderzoeksopzet, met name waar het de afbakening van de onderzoekspopulatie betreft en de informatie die via het monitoringinstrument dient te worden verzameld. Deze fase bestond uit literatuurstudie en interviews. Naar aanleiding van de bevindingen uit het vooronderzoek heeft het Ministerie van Onderwijs, Cultuur en Wetenschappen aan het ROA opdracht verleend om in een proefmeting na te gaan welk instrument, een schriftelijke enquête en of telefonische bevraging, het meest geschikt is om de bestemming van IVBO-schoolverlaters te registreren. In de tweede fase van het pilotproject (199511996) zijn beide instrumenten in een proefmeting onder IVBO-schoolverlaters van enkele Limburgse scholen getest.

Het vooronderzoek en de verslaglegging hiervan in deel 1 van het rapport is uitgevoerd door drs. P.J.E. van de Loo voor wat betreft het IVBO en door drs. G.W.M. Ramaekers voor wat betreft het VSO. De proefmeting onder schoolverlaters van het IVBO, alsmede de verslaglegging van de bevindingen in deel 2 van het rapport, is uitgevoerd door drs. G.W.M. Ramaekers. Hij is hierbij ondersteund door E.M.H.P. Soudant die vanuit het ROA de telefonische en schriftelijke proefenquêtes heeft uitgevoerd. Een woord van speciale dank geldt de dekanen van de in de proefmeting betrokken scholen.

Maastricht, november 1996 



\section{Inleiding}

\subsection{Aanleiding voor het pilot-project}

Sinds enige jaren wordt door het Researchcentrum voor Onderwijs en Arbeidsmarkt (ROA) in samenwerking met DESAN Marktonderzoek een uitstroomonderzoek gehouden onder schoolverlaters van het voortgezet onderwijs. Dit project, Registratie van de Uitstroom en Bestemming van Schoolverlaters (RUBS), omvat schoolverlaters (gediplomeerd en ongediplomeerd) van het voorbereidend beroepsonderwijs (VBO), algemeen voortgezet onderwijs en middelbaar beroepsonderwijs. Schoolver-laters van het individueel voorbereidend beroepsonderwijs (IVBO) en voortgezet speciaal onderwijs (VSO) worden in beginsel niet in het onderzoek betrokken, omdat het meetinstrument en de wijze van benadering (schriftelijke vragenlijst) voor deze groepen minder geschikt wordt geacht. Er bestaat voor VBO-scholen die dat wensen wel de mogelijkheid om ook oud-leerlingen van het IVBO aan het RUBS-onderzoek te laten deelnemen. Over deze groep wordt echter niet landelijk gerapporteerd.

In beleidskringen evenals bij de betrokken scholen zelf bestaat niettemin behoefte aan betrouwbare landelijke informatie over de uitstroom en bestemming van deze groepen schoolverlaters, zoals ook weer naar voren is gekomen op een studiedag ${ }^{1}$ van de Interdepartementale Stuurgroep Gehandicaptenbeleid. De bestaande statistieken van het Centraal Bureau voor de Statistiek (CBS) of de Gemeenschappelijke Medische Diensten (GMD's) schieten in dit opzicht tekort, terwijl het verrichte onderzoek op dit gebied ${ }^{2}$ een eenmalig karakter heeft en dus de kans loopt snel te verouderen. $\mathrm{Er}$ is derhalve behoefte aan een instrument dat op meer continue wijze de uitstroom en bestemming van deze groepen registreert. In opdracht van de Directie Voortgezet Onderwijs (VO) van het Ministerie van Onderwijs, Cultuur en Wetenschappen heeft het ROA onderzocht op welke wijze een dergelijk monitoringinstrument ontwikkeld kan worden.

\subsection{Opzet van het pilot-project}

Bij de ontwikkeling van een monitoringinstrument van de uitstroom en bestemming van schoolverlaters in het IVBO en VSO moet met een aantal bijzondere aspecten rekening worden gehouden:

- De onderzoekspopulatie is erg heterogeen. Niet alleen zijn er grote verschillen tussen het IVBO en het VSO, maar ook binnen beide schooltypen zijn er grote

1. Interdepartementale Stuurgroep Gehandicaptenbeleid. Themabijeenkomst over de relatie tussen onderwijs en arbeid voor gehandicapten, 22 oktober 1992, Zoetermeer.

2. Gortzak en Van der Linde (1991). 
verschillen. Zo kan het VSO worden onderverdeeld in VSO voor Leer- en Opvoedingsmoeilijkheden (VSO-LOM), VSO voor Moeilijk Lerende Kinderen (VSO-MLK), VSO voor Zeer Moeilijk Lerende Kinderen (VSO-ZMLK), VSO voor Zeer Moeilijk Opvoedbare Kinderen (VSO-ZMOK) en (V)SO-MYTYL en (V)SO-TYLTYL. Waarschijnlijk is het niet voor elke groep in het VSO zinvol om binnen het monitoringinstrument te worden opgenomen. Bovendien is het wellicht nodig om de verschillende groepen op een eigen manier te benaderen. Daarom is in ieder geval voor het IVBO en VSO afzonderlijk nagegaan welke mogelijkheden en randvoorwaarden er zijn voor het ontwikkelen van een instrument dat de uitstroom en bestemming meet van respectievelijk het IVBO en VSO.

- De onderzoekspopulatie, met name de schoolverlaters van het VSO, is deels een moeilijk te benaderen groep. Mede omdat het hier gaat om een relatief zwakke groep, is het mogelijk dat scholen zeer terughoudend zijn in het verstrekken van namen en adressen voor onderzoek. Ook wanneer deze adressen wel verstrekt worden, zal het moeilijk zijn om iedereen te achterhalen. Binnen deze groep komt het relatief vaak voor dat adressen onjuist blijken, mensen geen telefoon hebben of juist een geheim nummer, of dat mensen om een andere reden onbereikbaar zijn.

- De onderzoekspopulatie vormt een groep die een speciale wijze van dataverzameling lijkt te vereisen. De bereidheid om aan onderzoek mee te werken - zeker wanneer men vanuit een onbekende instantie benaderd wordt - is, zeker onder schoolverlaters van het VSO, vaak laag. Bij mondelinge of schriftelijke enquêtering kunnen snel problemen ontstaan als gevolg van het vereiste abstractieniveau of eventuele taalbarrières (relatief veel kinderen zijn afkomstig uit etnische minderheden).

Om deze redenen is besloten een pilot-onderzoek te verrichten naar de meest geschikte wijze om een dergelijk monitoringinstrument voor het IVBO en het VSO vorm te geven. In dit pilot-onderzoek zijn de volgende vragen aan bod gekomen:

1. Welke groepen schoolverlaters binnen het IVBO en VSO komen voor het uitstroomonderzoek in aanmerking?

2. Welke gegevens dienen over deze schoolverlaters te worden verzameld?

3. Op welke wijze en onder welke condities kan medewerking van de betrokken scholen worden verkregen?

4. Op welke wijze kan de dataverzameling het beste plaatsvinden en welke kosten zijn hiermee gemoeid?

Het pilot-onderzoek is in twee fasen uitgevoerd. In de eerste fase (1993/1994), waarvan deel 1 van dit rapport verslag doet, is door het ROA een nadere uitwerking gemaakt van de onderzoeksopzet, met name waar het de afbakening van de onderzoekspopulatie betreft en de informatie die via het monitoringinstrument dient te worden verzameld (onderzoeksvragen 1 en 2). Onderzoeksvraag 3 is in grote lijnen eveneens in deze fase aan bod gekomen. Naast literatuurstudie zijn interviews 
gehouden met sleutelfiguren bij direct betrokken organisaties als de interdepartementale Stuurgroep Gehandicaptenbeleid, SOMMA, GMD, Landelijk Werkverband VSO-MLK etc. Daarnaast hebben gesprekken plaatsgevonden met onderzoekers op dit terrein (LICOR) en met decanen van de betreffende scholen. Deze eerste fase van het pilot-project heeft geresulteerd in een voorstel om in één regio een proefmeting te houden onder schoolverlaters van het IVBO en in één of twee regio's een proefmeting onder schoolverlaters van het VSO (zie hoofdstuk 4). Naar aanleiding van dit voorstel heeft de Directie VO/A van het Ministerie van Onderwijs, Cultuur en Wetenschappen aan het ROA opdracht verleend om in een proefmeting na te gaan welk instrument het meest geschikt is om de bestemming van IVBO-schoolverlaters te registreren.

De tweede fase van het pilot-onderzoek (najaar 1994 - voorjaar 1996), waarvan deel 2 van dit rapport verslag doet, omvat de eigenlijke proefmeting onder schoolverlaters van het IVBO. Van belang hierbij is dat de ontwikkeling van het monitoringinstrument in de praktijk plaatsvindt, in nauwe samenwerking met de betrokken scholen. Deze tweede fase moet met name inzicht verschaffen in de eerdergenoemde onderzoeksvragen 3 en 4 en resulteren in een instrumentarium voor de periodieke registratie van de uitstroom en de bestemming van schoolverlaters van het IVBO.

\subsection{Leeswijzer}

In deel 1 wordt verslag gedaan van de eerste fase van het pilot-project. In hoofdstuk 2 en hoofdstuk 3 wordt achtereenvolgens voor het IVBO en het VSO aangegeven welke groepen voor het uitstroomonderzoek in aanmerking komen, welke gegevens over deze groepen schoolverlaters moeten worden verzameld en op welke wijze de benodigde gegevens zouden kunnen worden verzameld. Hoofdstuk 4 bevat de voorstellen voor de opzet van de regionale proefprojecten.

In het tweede deel worden de resultaten van de proefmeting onder schoolverlaters van het IVBO gepresenteerd. Hoofdstuk 5 en 6 beschrijt de drie instrumenten waarmee de dataverzameling heeft plaatsgevonden en de gevolgen hiervan voor de hoogte van de respons, de representativiteit van de enquêtes en de validiteit van de instrumenten. De belangrijkste resultaten met betrekking tot de bestemming van de respondenten komen aan bod in hoofdstuk 7 . Tenslotte worden in hoofdstuk 8 de bevindingen uit de proefmeting in het IVBO samengevat. 



\section{Deel 1}

Vooronderzoek meting bestemming schoolverlaters IVBO en VSO 



\section{Individueel voorbereidend beroepsonderwijs}

\subsection{Positie IVBO}

Wettelijk gezien bestaat er verschil tussen leerlingen van het individueel voorbereidend beroepsonderwijs en leerlingen die vakken op niveau $A$ (of $B$ ) van het voorbereidend beroepsonderwijs (VBO) volgen. Leerlingen mogen alleen tot het individueel VBO worden toegelaten indien een daartoe opgestelde test uitwijst dat zij geschikt zijn voor deze onderwijsvorm (de leerlingen met een l-indicatie). De vakken op A- (of B-)niveau zijn niet uitsluitend bedoeld voor deze l-leerlingen en omgekeerd kunnen Heerlingen dus vakken op C-/D-niveau volgen ${ }^{3}$. Leerlingen met een I-indicatie kunnen (officieel) dus niet zonder meer gelijk worden gesteld met VBO-A-leerlingen.

De praktijk is echter weerbarstiger. Onder decanen bestaat geen eenduidig begrip van de termen VBO-A- en I-leerlingen. Zoals Van Hooren (1993) heeft aangetoond, gebruikt iedere school hiervoor een andere omschrijving, zodat deze leerlingen - in de praktijk - niet eenduidig zijn gedefinieerd en kunnen worden afgebakend. Leerlingen van het VBO-A of met een I-indicatie hebben gemeen dat zij allen moeilijk lerend zijn. Een deel daarvan heeft daarvoor in het speciaal onderwijs de basisschool gevolgd en zou, volgens enkele decanen beter af zijn op een VSO/MLKschool (zie Van Hooren; 1993). Ook de grens tussen het speciaal onderwijs en het individueel voorbereidend beroepsonderwijs blijkt niet altijd even scherp te kunnen worden getrokken.

Dit vooronderzoek zal zowel leerlingen van het VBO-A als leerlingen met een Iindicatie betreffen. Deze totale groep zal worden aangeduid met de term: IVBO. In die gevallen waar uitsluitend VBO-A- of 1-leerlingen worden bedoeld, zal dit uitdrukkelijk in deze notitie worden vermeld.

Verder blijkt niet iedere school een afzonderlijke l-afdeling te hebben en is de positie van de I-leerlingen niet overal dezelfde. Er zijn scholen waar de IVBO-leerlingen relatief veel aandacht krijgen. Deze scholen profileren zich vaak ook echt als een IVBO-school. Daarentegen zijn er ook scholen waar deze leerlingen zijn 'ondergesneeuwd' of, zoals één van de decanen het uitdrukte 'net zijn ontdekt' als een voor de school belangrijke of interessante groep leerlingen. In ieder geval proberen de scholen de leerlingen met een 1-indicatie en/of met vakken op A-niveau in kleinere groepen onderwijs te laten volgen, zodat aan hen meer aandacht kan worden besteed.

3. Circa 10-15 procent van de schoolverlaters van het IVBO heeft één of meerdere vakken op C-/D-niveau gevolgd (zie RUBS-enquête 1992 en 1993). 
Tabel 2.1 geeft een overzicht van de (verwachte) aantallen gediplomeerden van het IVBO, onderverdeeld naar de technische, verzorgende en agrarische richting. Naar voren komt dat de landelijke uitstroom uit het IVBO de komende jaren naar verwachting verder zal toenemen. Alleen bij de richting verzorging zal het aantal gediplomeerden eerst licht dalen, alvorens na 1995 alsnog te stijgen.

Tabel 2.1

Aantallen gediplomeerden IVBO naar richting, 1990191-2010111

\begin{tabular}{llll}
\hline Studiejaar & IVBO-T & IVBO-V & ILO \\
\hline $1990 / 91$ & 4.926 & 3.589 & 1.274 \\
$1995 / 96$ & 5.546 & 3.199 & 1.391 \\
$2000 / 01$ & 5.621 & 3.583 & 1.504 \\
$2005 / 06$ & 6.042 & 4.047 & 1.663 \\
$2010 / 11$ & 6.405 & 4.282 & 1.767
\end{tabular}

IVBO-T Individueel Voorbereidend Beroepsonderwijs richting Techniek

IVBO-V Individueel Voorbereidend Beroepsonderwijs, richting Verzorging

ILO Individueel Landbouw Onderwijs

Bron: Ministerie van Onderwijs en Wetenschappen (1993)

\subsection{Schoolverlaters van het IVBO in de RUBS-enquête}

Deze voorstudie heeft betrekking op de mogelijkheden en randvoorwaarden voor het in kaart brengen ('monitoren') van de uitstroom en de bestemming van schoolverlaters van ondermeer het IVBO en VSO. leder jaar wordt er een enquête onder de schoolverlaters van het voortgezet onderwijs gehouden in het kader van het RUBSproject. Deze RUBS-enquête geeft inzicht in de maatschappelijke positie en arbeidsmarktintrede van deze schoolverlaters. De enquête verschaft daarnaast informatie over een groot aantal baankenmerken en over aspecten van de aansluiting tussen de genoten opleiding en de functie of de vervolgopleiding van deze schoolverlaters. In beginsel zijn het IVBO en VSO niet in de landelijke steekproef van de RUBSenquête betrokken, omdat de schriftelijke vragenlijst voor deze groep minder geschikt werd geacht. Echter, een aantal (I)VBO-scholen heeft eveneens haar VBOA-leerlingen laten meedoen aan deze RUBS-enquête. Dit biedt de mogelijkheid om na te gaan in hoeverre dit instrument kan worden ingezet voor het meten van de uitstroom en bestemming van schoolverlaters van het IVBO.

Hieronder zal eerst worden ingegaan op de respons onder de IVBO-leerlingen. Hierbij zal niet alleen worden nagegaan welk percentage IVBO-schoolverlaters, in vergelijking met de VBO-schoolverlaters, de vragenlijst heeft geretourneerd, maar eveneens worden ingegaan op de respons per vraag. Daarnaast heeft een check-up plaatsgevonden van de wijze waarop de vragenlijst is ingevuld. Zo wordt duidelijk waar de vragenlijst voor de IVBO'ers onduidelijk was, te moeilijk e.d. Vervolgens worden in het kort de belangrijkste onderzoeksresultaten weergegeven met betrek- 
king tot de maatschappelijke positie van de schoolverlaters ten tijde van de meting, naast een aantal baankenmerken van degenen die na de opleiding zijn gaan werken. Gegeven het doel van deze voorstudie zal de bespreking van deze onderzoeksresultaten slechts kort zijn.

\section{Respons}

Uit tabel 2.2 kan men aflezen dat de respons onder de schoolverlaters van het IVBO lager is dan onder de schoolverlaters van het VBO. Dit verschil in respons heeft met name betrekking op de gediplomeerde schoolverlaters. Over het algemeen geldt dat met het toenemen van het opleidingsniveau het responspercentage eveneens stijgt ${ }^{4}$. Voor dit soort onderzoek is een respons van $46 \%$ overigens wel acceptabel te noemen. De respons onder de ongediplomeerde schoolverlaters is zowel bij het IVBO als het VBO laag. Deels wordt dit veroorzaakt omdat deze populatie bij de steekproeftrekking niet goed afgebakend kan worden. lemand die op dezelfde of een andere school een andere opleiding is gaan volgen, wordt bijvoorbeeld tot de onderzoekspopulatie gerekend. Zelf zal iemand zich in een dergelijke situatie niet als een ongediplomeerde schoolverlater beschouwen, waardoor men ook minder geneigd zal zijn om de enquête in te vullen.

Tabel 2.2

Respons RUBS-enquête 1992 onder gediplomeerde en ongediplomeerde schoolverlaters van het IVBO ${ }^{5}$ en VBO

\begin{tabular}{lrrl}
\hline Schooltype & Uitgezet & Respons & $\begin{array}{l}\text { Respons- } \\
\text { percentage }\end{array}$ \\
\hline IVBO-gediplomeerd & 1794 & 825 & $46 \%$ \\
IVBO-ongediplomeerd & 489 & 106 & $22 \%$ \\
VBO-gediplomeerd & 13978 & 8386 & $60 \%$ \\
VBO-ongediplomeerd & 1745 & 467 & $27 \%$ \\
\hline
\end{tabular}

Bron: ROA (RUBS 1992)

In tabel 2.3 staat voor een aantal kernvragen uit de RUBS-enquêtes 1992 en 1993 het percentage schoolverlaters van het IVBO en VBO aangegeven dat de betreffende vraag niet of niet correct heeft ingevuld, terwijl deze vraag wel voor hen bedoeld was (de zogenaamde 'user missing values'). Deze kernvragen zijn onderverdeeld naar vragen die betrekking hebben op achtereenvolgens de persoons- en kwalificatiekenmerken en de arbeidsmarktintrede van de schoolverlaters, een aantal kenmer-

4. Het responspercentage voor de gediplomeerde schoolverlaters van het MBO bedraagt $70 \%$; voor het MAVO, HAVO en WWO respectievelijk $70 \%, 71 \%$ en $75 \%$ (zie RUBS 1992).

5. De schoolverlaters waarvan de deelnemende scholen hebben aangegeven dat zij een IVBO-opleiding hebben gevolgd, worden hierbij tot het IVBO gerekend. Met behulp van controlevragen is nagegaan of de schoolverlater daadwerkelijk deze IVBO-opleiding heeft gevolgd. 
ken van de baan van de werkende (i)VBO'ers en meningsvragen omtrent de studiekeuze en de aansluiting tussen de genoten opleiding en de huidige bezigheden. Op deze wijze kan inzicht worden verkregen in de vragen waarmee met name schoolverlaters van het IVBO 'moeite' hebben. Het kan zijn dat de betreffende vragen te abstract waren, onduidelijk, voor meerdere interpretaties mogelijk of te weinig herkenbaar voor de doorsnee schoolverlater van het IVBO. Het is evenwel ook mogelijk dat de schoolverlaters de betreffende vraag niet hebben ingevuld, omdat zij deze te persoonlijk vonden.

Uit tabel 2.3 blijkt dat het aandeel IVBO'ers dat de voor hen bedoelde vraag niet heeft ingevuld over het algemeen meevalt. Wel is het zo dat het percentage user missing values bij het IVBO doorgaans hoger is dan bij het VBO. De vragen die relatief minder vaak (correct) zijn ingevuld door de IVBO'ers, zijn ook bij de VBO'ers verhoudingsgewijs slecht beantwoord.

Bij de persoonskenmerken valt op dat gegevens omtrent het opleidingsniveau van de ouder(s), welke een indicator vormen van het sociaal milieu van de schoolverlater, relatief moeilijk te achterhalen zijn (onbekend en/of te persoonlijk). Het lijkt niet verstandig deze vraag als kernvraag te handhaven. Het percentage user missing values bij de vraag omtrent de postcode van het woonadres is zowel bij het IVBO als het VBO afgenomen.

Bij de vragen omtrent de kwalificaties van de schoolverlaters blijkt dat vragen over het jaar dat zij deze opleiding zijn begonnen, respectievelijk zijn beëindigd relatief vaak niet $\left(\right.$ goed $\left.^{6}\right)$ te zijn beantwoord. Dergelijke feitelijke retrospectieve vragen zijn blijkbaar te moeilijk voor schoolverlaters van het IVBO. Verder blijken veel schoolverlaters niet te kunnen of willen aangeven in welke gemeente de vervolgopleiding is gevestigd die zij op het moment van enquêteren volgen. Wellicht dat een deel van deze schoolverlaters deze vraag 'te persoonlijk' vindt. Terwijl de meeste schoolverlaters heel goed de deelname aan regulier vervolgonderwijs, leerlingwezen of inservice onderwijs aangeven, blijkt de deelname aan bijscholing moeilijker in kaart te brengen. Hierbij moet worden aangetekend dat de vraag naar een eventuele deelname aan bijscholing in één van de laatste vragenblokken is opgenomen. Enquêtemoeheid kan hierbij een rol spelen ${ }^{7}$.

6. De resultaten zijn ontleend aan een zogenaamd opgeschoond bestand. Aan vragen die niet correct leken te zijn beantwoord is de waarde 'missing value' toegekend.

7. Men kan in het algemeen stellen dat het aantal 'user missing values' toeneemt, naarmate de vragenlijst vordert. Echter, de vragen omtrent de persoonskenmerken zijn bij RUBS 1993 achterin de vragenlijst opgenomen, terwijl dit over het algemeen niet heeft geleid tot een toename van het aantal 'user missing values' voor deze kenmerken. Overigens lijkt de gebruikt RUBS-vragenlijst voor de schoolverlaters van het IVBO aan de lange kant.

10 
Tabel 2.3

Percentage user missing values IVBO- en VBO-schoolverlaters voor enkele kernvragen van RUBS-enquêtes 1992 (IVBO:N=913; VBO:N=9137) en 1993 (IVBO:N=492; VBO:N=5325)

\begin{tabular}{|c|c|c|c|c|}
\hline & \multicolumn{4}{|c|}{$\begin{array}{l}\text { Percentage user missing values } \\
\text { IVBO }\end{array}$} \\
\hline $\begin{array}{l}\text { Persoonskenmerken: } \\
\text { - leeftijd } \\
\text { - geslacht } \\
\text { - etniciteit } \\
\text { - postcode woonadres } \\
\text { - opleidingsniveau vader } \\
\text { - opleidingsniveau moeder }\end{array}$ & $\begin{array}{l}1 \\
0 \\
1 \\
6 \\
-- \\
--\end{array}$ & $\begin{array}{r}3 \\
1 \\
0 \\
2 \\
7+11^{8} \\
9+9^{6}\end{array}$ & $\begin{array}{l}1 \\
0 \\
1 \\
5 \\
-- \\
--\end{array}$ & $\begin{array}{r}3 \\
1 \\
0 \\
2 \\
6+9^{6} \\
7+8^{6}\end{array}$ \\
\hline $\begin{array}{l}\text { Kwalificatiekenmerken: } \\
\text { - jaar aanvang IVBO } \\
\text { - jaar einde IVBO } \\
\text { - naam vervolgopleiding } \\
\text { - gemeente vervolgopleiding } \\
\text { - deelname leerlingwezen/ } \\
\text { - in-service onderwijs } \\
\text { - deelname bijscholing }\end{array}$ & $\begin{array}{r}10 \\
\overline{1} \\
11 \\
2 \\
9\end{array}$ & $\begin{array}{r}10 \\
11 \\
1 \\
14 \\
0 \\
0 \\
10\end{array}$ & $\begin{array}{r}6 \\
\overline{1} \\
11\end{array}$ & $\begin{array}{l}7 \\
8 \\
1 \\
8\end{array}$ \\
\hline $\begin{array}{l}\text { Arbeidsmarktintrede: } \\
\text { - voornaamste bezigheid tijdens meting } \\
\text { - op zoek naar (ander) werk } \\
\text { - inschrijving bij arbeidsbureau } \\
\text { - beschikbaar voor arbeidsmarkt }\end{array}$ & $\begin{array}{l}2 \\
7 \\
2 \\
6\end{array}$ & $\begin{array}{r}1 \\
9 \\
1 \\
11\end{array}$ & $\begin{array}{l}1 \\
4 \\
2 \\
5\end{array}$ & $\begin{array}{l}2 \\
6 \\
4 \\
8\end{array}$ \\
\hline $\begin{array}{l}\text { Baankenmerken: } \\
\text { - dienstverband } \\
\text { - wekelijkse arbeidsduur } \\
\text { - wijze waarop baan is verworven } \\
\text { - beroep } \\
\text { - branche } \\
\text { - personeelsomvang } \\
\text { - gemeente werkadres } \\
\text { - vereist opleidingsniveau } \\
\text { - vereiste opleidingsrichting } \\
\text { - maandsalaris }\end{array}$ & $\begin{array}{r}6 \\
8 \\
9 \\
9 \\
11 \\
9+10^{6} \\
12 \\
14 \\
16 \\
22\end{array}$ & $\begin{array}{r}6 \\
8 \\
5 \\
6 \\
8 \\
9+12^{6} \\
10 \\
9 \\
11 \\
28\end{array}$ & $\begin{array}{r}6 \\
6 \\
6 \\
6 \\
7 \\
7+10^{6} \\
9 \\
9 \\
10 \\
21\end{array}$ & $\begin{array}{r}4 \\
11 \\
5 \\
5 \\
6 \\
7+13^{6} \\
7 \\
10 \\
9 \\
33\end{array}$ \\
\hline $\begin{array}{l}\text { Meningsvragen: } \\
\text { - aansluiting opleiding-bezigheid } \\
\text { - oordeel kennis-/vaardigheidsaspecten } \\
\text { - opnieuw keuze voor IVBO }\end{array}$ & $\begin{array}{r}9 \\
25-36 \\
--\end{array}$ & $\begin{array}{r}7 \\
19-24 \\
11\end{array}$ & $\begin{array}{r}4 \\
9-17 \\
--\end{array}$ & $\begin{array}{r}4 \\
9-17 \\
6\end{array}$ \\
\hline
\end{tabular}

-- : niet van toepassing

Bron: ROA (RUBS 1992 en 1993)

De vraag over de voornaamste bezigheid op het moment van enquêteren is in feite de belangrijkste vraag uit de RUBS-enquête. Deze vraag is over het algemeen goed ingevuld. In die gevallen dat deze vraag zelf niet was beantwoord, kon tijdens het opschonen van het databestand aan de hand van andere informatie uit de vragen-

8. Bij deze vraag is als user missing value eveneens de antwoordcategorie 'weet ik niet' toegevoegd. 
lijst de bestemming van de schoolverlaters vaak alsnog worden achterhaald. Voor het precies bepalen van de geregistreerde werkloosheid volgens de definitie van het CBS zijn vragen opgenomen over het zoeken naar (ander) werk, een eventuele inschrijving bij het arbeidsbureau en het spoedig beschikbaar zijn van de schoolverlater voor de arbeidsmarkt. Opvallend is hierbij dat de vraag naar een eventuele inschrijving bij het arbeidsbureau bij de IVBO'ers blijkbaar geen enkel probleem vormde, terwijl het aandeel 'user missing values' bij de andere twee vragen hierover redelijk hoog is te noemen.

Het procentuele aandeel schoolverlaters dat een vraag over een kenmerk van de baan niet (correct) heeft ingevuld, schommelt bij het IVBO tussen de 6 en 22 procent bij de RUBS-enquête 1992, terwijl dit percentage bij de RUBS-enquête 1993 tussen de 6 en 28 procent ligt. Toch geldt voor de meeste vragen omtrent de baankenmerken dat het aandeel 'user missing values' voor RUBS 1993 lager is dan voor RUBS 1992. Bij RUBS 1993 is het percentage IVBO'ers dat de vraag over het maandsalaris niet heeft ingevuld 6\% hoger dan bij RUBS 1992. Bij het VBO is dit percentage zelfs van 21 naar 33 procent gestegen. Bij RUBS 1992 is gevraagd naar het netto maandsalaris, terwijl bij RUBS 1993 naar het bruto maandsalaris is gevraagd. Hoewel het netto maandsalaris bij meer schoolverlaters van het (I)VBO bekend is, is desondanks besloten naar het bruto maandsalaris te vragen. Het bruto maandsalaris geeft namelijk een beter inzicht in het feitelijk inkomen dat schoolverlaters met een bepaalde functie verdienen. Dit laat onverlet dat moet worden geprobeerd de nonrespons op deze vraag te verkleinen. Verder is de non-respons aan de hoge kant voor vragen die betrekking hebben op het werkadres, de personeelsomvang van de organisatie waar de schoolverlater werkzaam is en de voor de functie vereiste opleiding (zowel naar niveau als richting).

Tot slot blijkt uit tabel 2.3 dat met name de meningsvragen over de mate waarin de IVBO-opleiding aandacht zou moeten besteden aan circa 20 kennis- en vaardigheidsaspecten een relatief hoge non-respons hebben. Voor het IVBO is deze nonrespons bovendien nog groter dan bij het VBO. Deze hoge non-respons kan verband houden met de omvang van de vraag: het aantal aspecten en de gehanteerde vijf-puntsschaal. Inmiddels is deze vraag ingedeeld in een viertal overzichtelijker blokken en wordt een drie-puntsschaal gehanteerd (meer, evenveel of minder aandacht voor betreffende aspect). Het is te overwegen om deze vragen, waarvan de antwoorden in de loop der jaren slechts in geringe mate wijzigen, niet ieder jaar in de vragenlijst op te nemen.

Zoals gezegd, heeft ook een zogenaamde 'invulanalyse' plaatsgevonden. Uit het totale aantal van 492 RUBS-enquêtes die in 1993 door IVBO-schoolverlaters zijn geretourneerd, is bij een steekproef van 130 vragenlijsten (ruim $25 \%$ ) nagegaan op welke wijze de vragenlijsten zijn ingevuld. Wanneer iedere vragenlijst nauwkeurig 
wordt gecheckt, blijkt dat er eigenlijk geen enkele vragenlijst volledig correct is ingevuld.

De invulanalyse heeft tot de volgende constateringen geleid. De in de vragenlijst genoemde doorverwijzingen zijn vaak niet opgevolgd. Bepaalde vragen die men mocht overslaan werden vaak ten onrechte beantwoord en vragen die men juist wel diende te beantwoorden zijn daarentegen overgeslagen. Het eerste vormt in de meeste gevallen geen probleem, het tweede brengt onnodig informatieverlies met zich mee. Daarnaast komt het voor dat bepaalde vragen, zonder dat er sprake is van doorverwijzigingen, niet worden beantwoord. Enerzijds gaat het hier om privacygevoelige vragen zoals het maandsalaris, anderzijds betreft het bijvoorbeeld retrospectieve vragen omtrent de jaren dat men de IVBO-opleiding heeft gevolgd.

Uit de invulanalyse blijken ook inconsequenties. Zo gaf een schoolverlater aan dat hij/zij niet binnen twee weken aan een nieuwe baan kan beginnen in verband met de opzegtermijn van de huidige baan, terwijl deze schoolverlater eerder aangeeft dat hij naast de studie geen betaald werk heeft. Of men geeft aan waarom men de opleiding voortijdig heeft verlaten, terwijl men het diploma van het IVBO wel heeft behaald. Verder wordt een vervolgopleiding in het dagonderwijs nogal eens verwart met een aanvullende cursus of een opleiding in het leerlingwezen of in-service onderwijs.

Ook komt het voor dat de schoolverlaters van het IVBO andere informatie opgeven dan de gevraagde informatie. Bijvoorbeeld het netto maandsalaris in plaats van het bruto maandsalaris of het uurloon in plaats van het maandloon. Daarnaast geeft men nogal eens aan dat de vraag niet op hen van toepassing is. In een aantal gevallen hebben de schoolverlaters meerdere antwoorden aangekruist, terwijl slechts één antwoord mocht worden gegeven.

Bovendien blijkt uit de invulanalyse dat met name de schoolverlaters van het IVBO moeite hebben met schrijven. Dit speelt uiteraard bij de open vragen een rol. De relatief veel voorkomende taalfouten maken het soms moeilijk om te begrijpen wat precies wordt bedoeld. Dit kan met name een probleem zijn bij het coderen van beroepen en branches. Daarnaast zijn de hokjes bij de gesloten vraag vaak 'kriebelig' aangekruist.

Een uitgebreid verslag van deze invulanalyse is opgenomen in bijlage 3 . In bijlage 4 is een kopie van de in 1993 gebruikte RUBS-vragenlijst toegevoegd.

\section{Onderzoeksresultaten}

Hieronder zal in het kort worden ingegaan op de belangrijkste inhoudelijke resultaten van de RUBS-enquêtes 1992 en 1993 voor het IVBO. Deze resultaten betreffen 
enerzijds de maatschappelijke positie van de IVBO'ers en anderzijds een aantal kenmerken van de banen waarin de schoolverlaters van het IVBO werkzaam zijn.

In tabel 2.4 staat de voornaamste bezigheid van de IVBO'ers op het moment van enquêteren aangegeven. In de meeste gevallen betreft dit de bestemming één jaar na afstuderen. Uit de resultaten blijkt dat het aandeel IVBO'ers dat na de opleiding verder is gaan leren tussen 1992 en 1993 fors is toegenomen van ruim eenderde naar bijna de helft van de schoolverlaters. Het percentage dat is gaan werken is daarentegen gedaald van 25 naar 17 procent. In beide jaren is het aandeel IVBO'ers dat naar het leerlingwezen gaat bijna éénderde.

De toename van het aandeel verder lerenden kan enerzijds een conjunctureel effect zijn. De snel verslechterende arbeidsmarktsituatie heeft geleid tot een grotere deelname aan vervolgonderwijs (liever studeren dan werkloos worden). Anderzijds is een structurele oorzaak ook mogelijk. Mensen proberen zo lang mogelijk door te leren om daarmee in de toekomst een betere uitgangspositie op de arbeidsmarkt te verkrijgen. Door het jaarlijks in kaart brengen van de bestemming van schoolverlaters kan worden nagegaan in hoeverre veranderingen toe te schrijven zijn aan conjuncturele dan wel structurele ontwikkelingen op de arbeidsmarkt.

Tabel 2.4

Voornaamste bezigheid van de schoolverlaters van het IVBO op het moment van enquêteren, 1992 en 1993

\begin{tabular}{lrr}
\hline & $\begin{array}{r}1992 \\
\%\end{array}$ & $\begin{array}{r}1993 \\
\%\end{array}$ \\
\hline Studie & 34 & 45 \\
Betaald werk & 25 & 17 \\
Leerlingwezen & 31 & 30 \\
Werkloos & 5 & 4 \\
Dienstplicht & 3 & 3 \\
Anders & 2 & 2 \\
Totaal (N=100\%) & 894 & 488 \\
\hline
\end{tabular}

Bron: ROA (RUBS 1992 en 1993)

Tabel 2.5 geeft inzicht in het overall-oordeel van de schoolverlaters over de aansluiting tussen de genoten IVBO-opleiding en hun huidige bezigheden, zoals de baan of de vervolgopleiding. Ruim driekwart van de IVBO'ers is van mening dat deze aansluiting goed of voldoende is. Beide cohorten verschillen nauwelijks wat het oordeel over deze aansluiting betreft.

De volgende tabellen hebben alleen betrekking op de schoolverlaters van het IVBO die voor minimaal 12 uur per week betaald werk hebben. De resultaten betreffen de functie die de werkende IVBO'ers op het moment van enquêteren uitoefenen. 
Tabel 2.5

Oordeel van de schoolverlaters van het IVBO over de aansluiting tussen de IVBO-opleiding en de bezigheden op het moment van enquêteren, 1992 en 1993

\begin{tabular}{|c|c|c|c|c|}
\hline & & & $\begin{array}{r}1992 \\
\%\end{array}$ & $\begin{array}{r}1993 \\
\%\end{array}$ \\
\hline $\begin{array}{l}\text { Aansluiting is: } \\
\text { - goed } \\
\text { - voldoende } \\
\text { - matig } \\
\text { - slecht }\end{array}$ & & & $\begin{array}{r}47 \\
29 \\
15 \\
9\end{array}$ & $\begin{array}{l}46 \\
30 \\
14 \\
11\end{array}$ \\
\hline Totaal $(\mathrm{N}=100 \%)$ & 833 & 488 & & \\
\hline
\end{tabular}

Bron: ROA (RUBS 1992 en 1993)

In tabel 2.6 staat aangegeven op welke wijze de werkende IVBO'ers hun baan hebben verworven. Opvallend is dat ruim één op de vijf IVBO'ers aan de slag is gekomen door zelf op de werkgever af te stappen. Ongeveer een zelfde aantal schoolverlaters heeft de baan via de stage of school verkregen. Zoals ook Van Hooren (1993) stelt, hebben veel scholen extra aandacht voor de IVBO'ers op het moment van dat zij de school verlaten en bestaan er nauwe contacten tussen de scholen en de consulenten van het Regionaal Dienstverlenend Centrum (RDC). Verder valt op dat het percentage werkenden dat via familie of kennissen aan de baan is gekomen, tussen 1992 en 1993 is gehalveerd. Het verwerven van een baan door het reageren op een advertentie, is voor de IVBO'ers, net als voor de VBO'ers en KMBO'ers, een minder succesvol kanaal. Het aandeel dat via het jeugdwerkgarantieplan een baan verwerft, is nog steeds laag. De categorie 'anders' bestaat voor circa de helft uit IVBO'ers die door de werkgever zelf voor het vervullen van de baan zijn gevraagd.

Tabel 2.6

Wijze waarop de werkzame schoolverlaters van het IVBO de baan hebben verworven, 1992 en 1993

\begin{tabular}{lrr}
\hline & 1992 & 1993 \\
& $\%$ \\
\hline & & 10 \\
Reageren op advertentie & 11 & 8 \\
Arbeidsbureau & 8 & 8 \\
Uitzendbureau & 6 & 4 \\
Vakantiewerk, bijbaantje & 6 & 2 \\
Eerder betaald werk & 1 & 12 \\
Familie, kennissen & 21 & 22 \\
Via stage of school & 25 & 23 \\
Open sollicitatie, zelf gevraagd & 21 & 3 \\
Jeugdwerkgarantieplan e.d. & 1 & 8 \\
Anders & 1 & 488 \\
Totaal (N=100\%) & 439 & \\
\hline
\end{tabular}

Bron: ROA (RUBS 1992 en 1993) 
Het voor de functie vereiste opleidingsniveau in tabel 2.7 biedt inzicht in een eventuele onderbenutting van de capaciteiten van de werkende IVBO'ers in hun huidige baan. Wanneer iemand een baan uitoefent beneden zijn of haar opleidingsniveau is er sprake van een potentiële onderbenutting van kwalificaties. Een eventuele onderbenutting hangt vaak samen met verdringingsprocessen. Mensen met een hogere scholing verdringen, op een ruime arbeidsmarkt, vaak mensen in functies die voorheen door lager geschoolden werden vervuld.

Tabel 2.7

Vereiste opleidingsniveau en -richting voor de baan van de werkzame schoolverlaters van het IVBO, 1992 en 1993

\begin{tabular}{lrc}
\hline & 1992 & 1993 \\
& $\%$ & $\%$ \\
\hline Vereist opleidingsniveau: & & \\
- Lagere school voldoende & 31 & 12 \\
- VBO & 54 & 73 \\
- MAVO & 0 & -- \\
- leerlingwezen, KMBO & 13 & - \\
- HAVONWO & - & 2 \\
- MBO & 2 & -- \\
- HBO & -- & 183 \\
Totaal (N=100\%) & 414 & 37 \\
Vereiste opleidingsrichting: & & 6 \\
- richting die ik zelf heb gevolgd & 33 & 58 \\
- andere richting & 2 & 179 \\
- geen speciale richting & 65 & \\
Totaal (N=100\%) & 403 & \\
\hline
\end{tabular}

-- : niet van toepassing

Bron: ROA (RUBS 1992 en 1993)

Terwijl in 1992 ruim tweederde van de werkende IVBO'ers een baan had op minimaal VBO-niveau, is dit toegenomen tot $88 \%$ in 1993. Dit verschil wordt veroorzaakt door een verschuiving van banen waarvoor een lagere schoolopleiding voldoende is naar banen waarvoor minimaal een VBO-diploma door de werkgever werd vereist. Of hierbij sprake is van een trend of een eenmalige verschuiving kan pas worden nagegaan na het herhaaldelijk meten van de voor de baan minimaal gestelde opleidingseisen. Op zich is het wel opvallend dat in een periode van een verslechterende arbeidsmarkt het percentage schoolverlaters dat potentieel wordt onderbenut daalt. Echter, door het grotere aandeel schoolverlaters dat verder is gaan leren en zich dus niet heeft gemeld op de arbeidsmarkt, is het aanbod van schoolverlaters op de arbeidsmarkt sterk gedaald. Hierdoor zijn de kansen op (passend) werk toegenomen voor degenen die zich wel hebben aangeboden op de arbeidsmarkt. 
Uit tabel 2.7 blijkt verder dat voor de meerderheid van de banen van de IVBO'ers geen speciale vakrichtingen zijn vereist. Voor zover er voor de baan wel een speciale vakrichting werd vereist gaat het om de vakrichting die de IVBO'ers zelf hebben gevolgd.

Tabel 2.8 geeft een overzicht van de belangrijkste beroepen waarin de schoolverlaters van het IVBO werkzaam zijn. In dit overzicht zijn de beroepen genoemd waarin, in zowel 1992 als 1993, minimaal $2 \%$ van de werkende IVBO'ers op het moment van enquêteren werkzaam is. Het gaat hier in alle gevallen om - vaak ambachtelijke functies op het uitvoerende niveau. Wanneer wordt gekeken naar de beroepssector waarin de IVBO'ers werkzaam zijn, kan worden geconstateerd dat ongeveer zes op de tien IVBO'ers een ambachtelijk of industrieel beroep uitoefenen. Ongeveer $10 \%$ van de werkzame IVBO'ers heeft respectievelijk een commerciële, een dienstverlenende of een agrarische functie. Slechts 2 á 4 procent oefent een administratieve functie uit.

Tabel 2.8

Beroepen waarin minimaal $2 \%$ van de werkende schoolverlaters van het IVBO werkzaam is 1992 en 1993

\begin{tabular}{lrr}
\hline & 1992 & 1993 \\
& $\%$ & \\
& & 11 \\
Winkelbediende & 13 & 3 \\
Kok & 2 & 4 \\
Tuinmansknecht & 3 & 2 \\
Lasser (metaal) & 3 & 4 \\
Constructiebankwerker & 3 & 6 \\
Huisschilder & 3 & 3 \\
Metselaar (algemeen) & 4 & 5 \\
Bouwvaktimmerman & 8 & 50 \\
Inpakker (industrieel) & 3 & 189 \\
Aandeel belangrijkste beroepen & & 5 \\
in totale werkgelegenheid IVBO & 42 & \\
Totaal (N=100\%) & 438 & \\
\hline
\end{tabular}

Bron: ROA (RUBS 1992 en 1993)

In tabel 2.9 staat een overzicht van de branches waarin, in zowel 1992 als 1993 , minimaal $2 \%$ van de werkende IVBO'ers op het moment van enquêteren een baan had. Het gaat voornamelijk om ambachtelijke en industriële bedrijven, naast een aantal dienstverlenende branches.

Het is hierbij relevant om te weten of de IVBO'ers nu juist vaak werken in het midden- en kleinbedrijf of dat zij veelal werkzaam zijn in grote bedrijven. In tabel 2.10 komt naar voren dat schoolverlaters van het IVBO voor het merendeel werkzaam zijn in (zeer) kleine bedrijven: in 1992 en 1993 heeft respectievelijk 75\% en $72 \%$ een baan in een bedrijf met maximaal 50 personeelsleden. Ongeveer $15 \%$ van 
de werkende IVBO'ers werkt in een bedrijf met minimaal 100 werknemers. Deze resultaten stemmen in hoge mate overeen met de omvang van de bedrijven waarin VBO'ers terecht zijn gekomen.

Tabel 2.9

Branches waarin minimaal $2 \%$ van de werkende schoolverlaters van het IVBO werkzaam is 1992 en 1993

\begin{tabular}{lrr} 
& & 1993 \\
& $\%$ \\
\hline Tuinbouw & $\%$ & 6 \\
Plantsoendienst, hoveniersbedrijf & 3 & 3 \\
Machine-industrie & 2 & 3 \\
Aannemersbedrijf & 13 & 18 \\
Schilders-/glazeniersbedrijf & 3 & 3 \\
Detailhandel levensmiddelen & 9 & 4 \\
Restaurant & 3 & 42 \\
Aandeel belangrijkste branches & & 185 \\
in totale werkgelegenheid IVBO & 37 & 428 \\
Totaal (N=100\%) & 428 & \\
\hline
\end{tabular}

Bron: ROA (RUBS 1992 en 1993)

Tabel 2.10

Personeelsomvang van het bedrijf waarin de werkende schoolverlaters van het IVBO werkzaam zijn, 1992 en 1993

\begin{tabular}{lrr}
\hline & 1992 & $1993^{9}$ \\
$\%$ & $\%$ & 39 \\
& & 35 \\
minder dan 10 personen & 40 & 33 \\
10 tot 50 personen & 10 & 12 \\
50 tot 100 personen & 14 & 16 \\
Tot meer personen & 395 & 159 \\
\hline
\end{tabular}

Bron: ROA (RUBS 1992 en 1993)

\subsection{Randvoorwaarden voor meting van de bestemming}

Zoals eerder is aangegeven, beoogt het vooronderzoek na te gaan welke mogelijkheden er zijn om een instrumentarium te ontwikkelen voor de registratie van de uitstroom en de bestemming van schoolverlaters van het IVBO en het VSO. Voor het IVBO zou het doel van deze registratie de volgende dienen te zijn: het periodiek

9. De gegevens tussen 1992 en 1993 zijn niet geheel met elkaar te vergelijken. In de RUBSenquête 1993 is uitdrukkelijk vermeld dat het gaat om het totaal aantal werknemers van het betreffende bedrijf in Nederland. In 1992 is deze vermelding achterwege gelaten, zodat respondenten dit kunnen hebben opgevat als het aantal werknemers dat werkzaam is bij alleen de vestiging van het bedrijf waar de schoolverlater werkzaam is. 
(jaarlijks) in kaart brengen van de uitstroom en bestemming (op de arbeidsmarkt, in het vervolgonderwijs of anderszins) van gediplomeerde en ongediplomeerde schoolverlaters van het IVBO.

Middels een aantal vraaggesprekken met decanen van scholen met IVBO-leerlingen is onderzocht of zij dit doel onderschrijven, in hoeverre de onderzoeksgroep en onderzoeksonderwerpen naar hun mening zouden moeten worden afgebakend, en op welke wijze de gegevensverzameling georganiseerd zou moeten worden. In bijlage 2 is de lijst van gesprekspunten bijgevoegd die tijdens de interviews ter sprake zijn gebracht. Het betrof derhalve een voorgestructureerd interview. Het aantal gesprekspartners was gegeven de omvang van het onderzoek weliswaar klein, maar geeft wel een goed inzicht in de mogelijkheden en randvoorwaarden voor het ontwikkelen van bovengenoemd instrumentarium.

De decanen zijn allen afkomstig van Limburgse VBO-scholen, uit verschillende sectoren (technisch, verzorgend, economisch-administratief). De ene school heeft een duidelijker I-profiel dan de andere. Al deze scholen hebben geparticipeerd in het RUBS-onderzoek en de decanen waren redelijk tot goed op de hoogte van de werkwijze die bij RUBS wordt gehanteerd. Het RUBS-onderzoek vinden zij belangrijk, maar zij vinden het moeilijk om de resultaten direct te vertalen naar het 'onderwijs en schoolleven van alledag'. In ieder geval vind men dat het RUBS-onderzoek belangrijke achtergrondinformatie bevat voor de scholen.

Met name de decanen zijn geïnteresseerd in de vraag waar de schoolverlaters (uiteindelijk) naar toe zijn gegaan en of deze keuze hen bevalt. Door onder meer de contacten met de RDC-consulenten en decanen of docenten van het vervolgonderwijs hebben de decanen voor wat betreft de gediplomeerde (IVBO) schoolverlaters een redelijk beeld van de eerste bestemming. Daarna verliezen de meeste decanen snel het zicht op wat er verder met de schoolverlaters gebeurt. Voor de ongediplomeerde (voortijdig) schoolverlaters geldt dat docenten en decanen via (vroegere) medeleerlingen nog enige tijd op de hoogte kunnen blijven van het wel en wee van deze schoolverlaters. Echter, meestal is het contact met vroegere klasgenoten binnen een jaar verbroken.

Het eerder genoemde doel van het registratie-instrument wordt door alle decanen onderschreven. Zij geven ook allen aan dat bereid zijn aan een eventueel vervolgonderzoek deel te nemen, zodat in de praktijk kan worden nagegaan welk instrument het beste werkt.

De scholen verwachten dat het onderzoek in de eerste plaats dezelfde soort informatie oplevert als bij het RUBS-onderzoek het geval is. Gegeven het feit dat het in de aanloopfase niet om een landelijk proefonderzoek gaat, betekent dit een instellingsrapportage met cijfers over de arbeidsmarktintrede van de 'eigen' schoolverla- 
ters. De gegevens zouden hierbij moeten worden uitgesplitst naar vakrichting, zoals nu ook bij het RUBS-onderzoek het geval is. De decanen hechten er overigens wel aan dat, bij een landelijke opzet, de resultaten van de eigen school kunnen worden vergeleken met overeenkomstige vakrichtingen in de rest van het land. Om de vertaalslag tussen onderzoeksresultaten en een eventuele aanpassing van het onderwijs te vergemakkelijken, hebben de decanen er geen moeite mee indien het (landelijke) rapport daarvoor een aantal (vrijblijvende) suggesties aanreikt. Bovendien gaf één van de decanen aan dat hij daarnaast belangstelling heeft voor nietanonieme resultaten. Hij wil graag weten waar een bepaalde leerling (met naam en toenaam) na de opleiding naar toe is gegaan, hoe deze keuze hem/haar bevalt en eventueel ook hoe deze leerling de IVBO-opleiding beoordeelt in het licht van zijn/haar huidige bezigheden. Dit vergroot volgens hem het inzicht in de resultaten en daarmee de betrokkenheid van decanen en docenten bij het onderzoek. Gegeven de Wet op de persoonsregistraties (WPR), aan welke voorwaarden het RUBSonderzoek eveneens voldoet, is het dan wel noodzakelijk om de schoolverlaters, ook bij dit onderzoek, toestemming te vragen voor het aan de school verstrekken van niet-anonieme gegevens. Dit gebeurt reeds standaard in het RUBS-project. In dat project wordt van de schoolverlaters die hiervoor toestemming hebben verleend, standaard bepaalde informatie aan de scholen verstrekt.

\section{Afbakening onderzoekspopulatie en onderzoeksonderwerpen}

De belangrijkste vraag hierbij is of het onderzoek alleen de gediplomeerde IVBO'ers zou moeten betreffen of ook de ongediplomeerde schoolverlaters. Gezien de bijzonder lage respons onder de ongediplomeerde schoolverlaters, is de kosten-lopbrengstverhouding voor deze groep ongunstig. Hierbij zou onderscheid gemaakt moeten worden tussen degenen die het laatste jaar wel gevolgd hebben, maar het diploma uiteindelijk niet hebben behaald, waarna zij de school hebben verlaten, en schoolverlaters die reeds voor het examenjaar de opleiding voortijdig hebben beëindigd.

De decanen geven aan dat de IVBO'ers die het examenjaar volgen zonder het diploma te behalen het jaar daarop meestal opnieuw aan het examen deelnemen (en het diploma dan alsnog behalen). Een groter probleem vormt de groep voortijdig schoolverlaters. De eerste maanden na het verlaten van de school zijn deze schoolverlaters over het algemeen nog wel te achterhalen. Echter, na een jaar is het zicht hierop meestal verdwenen. Dit geldt met name voor schoolverlaters die uit de relatief anonieme - stad komen. De decanen vinden het zinvol om van deze groep te weten waarom zij de school hebben verlaten en waar zij naar toe zijn gegaan. Hierbij moet worden bedacht dat de laatste jaren veel projecten zijn gestart om de drop-out problematiek zoveel mogelijk tegen te gaan. Het is in ieder geval van belang dat, in combinatie met drop-out bestrijdingsprojecten, een goede registratie tot stand komt van de omvang, oorzaken en gevolgen van voortijdig schoolverlaters. Hierbij moet 
worden geprobeerd om bijvoorbeeld via 'mentoren' langer contact te houden met deze voortijdig schoolverlaters.

\section{Wie verstrekt de gegevens?}

Een andere vraag is of de schoolverlaters van het IVBO zèlf worden benaderd om aan het onderzoek deel te nemen, of dat anderen de vragen voor deze schoolverlaters beantwoorden (zie tabel 2.11). Een combinatie hiervan is uiteraard ook mogelijk. Het moge duidelijk zijn dat zogenaamde meningsvragen alleen beantwoord kunnen worden door de IVBO'ers zelf. Gegevens die ook bij anderen (bijvoorbeeld de ouders of verzorgers) bekend zijn, kunnen eventueel ook door deze derden worden verstrekt. De ene decaan vindt dat de IVBO'ers zelf moeten worden benaderd, terwijl anderen van mening zijn dat hierbij ook de ouders of verzorgers direct bij kunnen worden ingeschakeld. De meeste IVBO-leerlingen wonen nog thuis. Een aantal verblijft in een internaat of is opgenomen in begeleid-wonen-project. De decanen vinden het direct betrekken van werkgevers bij de gegevensverzameling een minder goede keuze. Al staat het IVBO'ers natuurlijk vrij om aan de werkgever te vragen wat bijvoorbeeld het bruto maandinkomen nu precies is. Het via de vervolgopleiding benaderen van de (verder lerende) IVBO'er kan een optie zijn. In dat geval dient het instrument ook vragen te bevatten over de vorderingen van de IVBO'er op deze vervolgopleiding en eventueel over het oordeel van de IVBO'er over dit vervolgonderwijs. De resultaten hiervan zouden dan ook aan deze vervolgopleiding gerapporteerd dienen te worden. Hiermee verschuift dit onderzoek overigens van uitstroomnaar in- en doorstroomonderzoek.

Tabel 2. 11

Mogelijke informatieverstrekkers voor onderzoek naar de uitstroom en bestemming van schoolverlaters van het IVBO en oordeel daarover door decanen

\begin{tabular}{ll}
\hline & Positief $(+)$ of Negatief $(-)$ oordeel \\
\hline Schoolverlater zelf & +++ \\
Ouder(s)/verzorger(s) & ++ \\
Administratie IVBO-school & +++ \\
Decaan/docent IVBO & ++ \\
Decaan/docent vervolgopleiding & + \\
Werkgever & $+/-$
\end{tabular}

Bron: ROA

Mede vanwege de vertrouwensrelatie tussen de IVBO'ers en de docenten die hen les hebben gegeven, vinden de decanen het daarnaast zinvol dat deze docenten bij het onderzoek worden ingeschakeld. Dat kan tijdens de gegevensverzameling zelf zijn (bij een telefonische enquête of interview, het begeleidend schrijven bij een schriftelijke enquête) of bij een bijeenkomst, al dan niet tijdens een reünie, over de wijze waarop de overgang van het IVBO naar het vervolgonderwijs of de arbeidsmarkt is verlopen. Bovendien is het aan te bevelen wanneer docenten of decanen 
een dergelijk onderzoek bij de leerlingen 'in de week' zetten. Dit kan door de resultaten van de voorafgaande lichting met de leerlingen uit het examenjaar bespreken en hen er op attenderen dat zij na de opleiding ook voor hetzelfde onderzoek worden benaderd. Daarnaast is het van belang dat docenten en decanen bij de verdere uitwerking van het onderzoek worden betrokken. Een van de decanen maakte hierbij wel de kanttekening dat het geheel niet zo zwaar moet worden opgetuigd, dat de uitvoerbaarheid in de knel komt.

\section{Achtergrondinformatie via schooladministratie}

Men vindt het wel een goed idee, wanneer de deelnemende scholen vooraf aan de onderzoekers informatie verstrekken over een aantal achtergrondvariabelen. In de huidige RUBS-enquête worden allerlei achtergrondgegevens aan de schoolverlater gevraagd, terwijl de meeste scholen zelf over deze gegevens beschikken. Het vooraf verstrekken van een aantal achtergrondgegevens heeft als voordeel, dat daarmee rekening kan worden gehouden bij de dataverzameling. De decanen gaven aan dat het grootste gedeelte van deze gegevens op de school aanwezig zijn. Uiteraard dienen enkele vragen nog wel opgenomen te worden als zogenaamde controlevariabelen. Om de vragenlijst zo beknopt mogelijk te houden zou het aantal controlevariabelen echter fors kunnen worden gereduceerd. In tabel 2.12 zijn de achtergrondvariabelen genoemd die eventueel door de schooladministratie zouden kunnen worden verstrekt, met inachtneming van WPR-richtlijnen. De mate van beschikbaarheid is eveneens gebaseerd op ervaringen vanuit het RUBS-onderzoek.

\section{Enquêtemoment}

Daarnaast gaat het om de vraag op welk moment na het verlaten van de school de bestemming in kaart moet worden gebracht. Hierbij dient met een aantal zaken rekening te worden gehouden. Ten eerste de vergelijkbaarheid van de gegevens met ander onderzoek, zoals de RUBS-enquête. Bij het RUBS-onderzoek worden de schoolverlaters vanaf 1996 ongeveer anderhalf jaar na het verlaten van de school geënquêteerd. Daarmee is het meetmoment geïntegreerd met het moment waarop binnen het $\mathrm{HBO}$ (de HBO-Monitor) en het WO (de WO-Monitor) de meting onder afgestudeerden plaatsvindt. Door het meetmoment op ruim een jaar na afstuderen te leggen, wordt niet alleen zicht verkregen op de arbeidsmarktintrede, maar kan ook geanalyseerd worden hoe de doorstroom naar vervolgonderwijs is verlopen.

In aansluiting hierop zou men zich in de tweede plaats dienen af te vragen welk soort informatie men wil verkrijgen. De decanen geven aan dat zij enerzijds geïnteresseerd zijn in het intredeproces op de arbeidsmarkt van de IVBO'ers. Anderzijds willen zij, juist van deze groep schoolverlaters, graag weten in hoeverre de IVBO'ers slagen in het vervolgonderwijs. Zoals een van de decanen zei, zijn IVBO'ers vaak 
heel erg gemotiveerd en willen graag verder leren. Omdat je hen daarom zo graag een behoorlijke schoolloopbaan gunt, is het des te triester als het dan niet lukt in het vervolgonderwijs. De IVBO-leerlingen zijn vaak heel erg onzeker over hun eigen kunnen. Een belangrijk deel van de IVBO-opleiding is gericht op het vergroten van het zelfbewustzijn van de leerlingen. Wanneer deze leerlingen het niet bolwerken in een vervolgopleiding, komen veel IVBO'ers (opnieuw) in het dal terecht waar je ze juist uit hebt proberen te halen. Het is voor deze groep dus niet makkelijk om een passend studie-advies te geven.

Tabel 2.12

Mogelijke gegevens die vooraf door de schooladministratie worden verstrekt voor het onderzoek naar de uitstroom en bestemming van schoolverlaters van het IVBO

Beschikbaar op school

Naam, adres (ouderlijk en/of van schoolverlater)

Telefoonnummer

Sexe

Leeftijd

Etniciteit

Gevolgde IVBO-opleiding (richting en niveau vakken)

Jaar/klas aanvang opleiding

Laatst gevolgde studiejaar/klas

Wel/geen diploma

Vooropleiding

Wel/niet doubleren (en in welke klas)

Wel/niet IVBO aan andere school gevolgd (en welke)

Wel/niet aan andere school verder gegaan

Naam vervolgopleiding en vervolgschool

$1 \mathrm{e}$ bestemming na verlaten school

Bron: ROA

\section{Onderzoeksondenwerpen}

De decanen is een lijst voorgelegd met mogelijke onderwerpen die in het schoolverlatersonderzoek zouden kunnen worden opgenomen. Deze onderwerpen zijn voor een belangrijk deel ontleend aan de RUBS-enquête. De voorgelegde onderwerpen zijn onderverdeeld naar vragen die betrekking hebben op alle oudleerlingen van het IVBO, op schoolverlaters die op het enquêtemoment werkzaam zijn en op IVBO'ers die verder zijn gaan leren. Het ROA had hierbij al een voorselectie gemaakt naar belangrijke en minder belangrijke onderwerpen. Over het algemeen onderschrijven de decanen de keuze van de onderzoeksonderwerpen. Ook voor hen is het belangrijk dat hierbij waar mogelijk wordt aangesloten op de vragen die in de RUBS-enquête zijn opgenomen.

De decanen geven aan dat het instrument, naast het in kaart brengen van de arbeidsmarktpositie van schoolverlaters, ook informatie moet verschaffen over de positie van de IVBO'ers in het vervolgonderwijs. Ook zou men zich kunnen afvragen 
of alle vragen ieder jaar opnieuw in de vragenlijst zouden moeten worden opgenomen. Het is ook mogelijk om een aantal vragenblokken te rouleren. Zeker gezien het feit dat bepaalde zaken in de loop der jaren niet schoksgewijze verschuiven. Het kan bovendien geen kwaad wanneer de vragenlijst wordt ingekort. Voor schoolverlaters van het IVBO is deze aan de lange kant.

De respons- en invulanalyses, alsmede de gesprekken met de decanen geven geen eenduidig uitsluitsel op de vraag of de RUBS-vragenlijst die voor het VBO wordt gehanteerd, (in zijn geheel) nu niet of wel kan worden ingezet voor een meting onder de schoolverlaters van het IVBO. De integrale respons en de respons per vraag is voor de IVBO'ers weliswaar lager dan bij de VBO'ers, maar de respons is over het algemeen wel voldoende om (op landelijk niveau) zinvolle uitspraken over de resultaten te kunnen doen. Wanneer men kiest voor een verkorte vragenlijst verhoogt dat de kans op een hogere respons, maar men gooit daarmee, doordat vragen achterwege worden gelaten, op voorhand informatie weg. Voor het proefonderzoek wordt daarom voorgesteld om twee alternatieven in de praktijk te toetsen. Enerzijds zal een vragenlijst worden beproefd die in grote lijnen overeenkomt met de RUBSvragenlijst die voor het VBO wordt gebruikt. De meningsvragen over de kwalitatieve aansluiting tussen de IVBO-opleiding en de belangrijkste bezigheid op het enquêtemoment kunnen daarbij door een deel van deze eerste groep wel worden beantwoord, terwijl ter vergelijking een ander deel deze vragen, waarop de non-respons nogal groot is gebleken, niet krijgt voorgelegd. Anderzijds kan worden onderzocht in hoeverre een sterk verkort vragenformulier de respons in kwantiteit en kwaliteit verhoogt. Om na te gaan welk instrument in de toekomst het beste kan worden benut is een uitgebreid non-responsonderzoek van belang. Het gaat er dan niet zo zeer om na te gaan in hoeverre de respons selectief is geweest, maar veeleer om het in kaart brengen van de verschillen in redenen voor het niet willen of kunnen deelnemen aan het onderzoek tussen de schoolverlaters die met de verschillende onderzoeksinstrumenten zijn benaderd.

In tabel 2.13 worden, mede op basis van de reactie van de decanen, de onderzoeksonderwerpen aangegeven die in het onderzoek zouden moeten worden opgenomen. Bij het opstellen van bovenstaande lijst van relevante onderwerpen is ervan uitgegaan dat een aantal achtergrondvariabelen vóóraf door de deelnemende school wordt verstrekt.

Tabel 2.13a bevat de onderzoeksonderwerpen die in de sterk verkorte vragenlijst zouden kunnen worden opgenomen. Tabel $2.13 \mathrm{~b}$ laat zien welke onderzoeksonderwerpen in principe aan bod zouden moeten komen in een vragenlijst die aansluit bij de RUBS-vragenlijst. Een deel van de vragen zijn hierbij voor alle respondenten bedoeld, een deel voor de werkenden en een deel voor degenen die verder zijn gaan leren. Schoolverlaters die een vervolgopleiding combineren met betaald werk, zoals bij het leerlingwezen het geval is, zouden dan beide delen van de vragenlijst 
moeten invullen. Uit de invulanalyse blijkt dat de schoolverlaters van het IVBO met name problemen hebben met de doorverwijzingen. De routing zal dus zo eenvoudig mogelijk moeten zijn.

Tabel 2.13a

Onderzoeksonderwerpen voor de verkorte bestemmingsmeting naar de positie op de arbeidsmarkt en in het vervolgonderwijs van (gediplomeerde) IVBO'ers

Integrale verkorte meting

G controlevraag over gevolgde IVBO-opleiding

0 totaal aantal maanden dat IVBO'er na opleiding werkloos is geweest

G voornaamste bezigheid op enquêtemoment: leerlingwezen, scholier, betaaldwerk, onbetaald werk, huishouden, werkloos, militaire/vervangende dienstplicht, anders:

0 vervolgopleiding na verlaten IVBO (dagopleiding, leerlingwezen): naam en plaats van opleiding en school

$G$ vraag of men deze opleiding nog volgt

0 naam beroep enquêtemoment en korte omschrijving van de werkzaamheden na verlaten IVBO

0 wanneer in deze baan begonnen?

0 naam, branche en plaats van de organisatie waar men werkt

G soort dienstverband (inclusief bijzondere regelingen als WSW, WetVermeend/Moor e.d.)

$G$ op zoek naar (ander) werk

$G$ voor minimaal 12 uur per week betaald werk willen hebben

$G$ als werkzoekende ingeschreven bij arbeidsbureau

$G$ binnen 2 weken beschikbaar voor (ander) werk

$G$ algemene beoordeling voorbereiding IVBO-opleiding op betaald werk

$G$ vraag of ook niet-anonieme resultaten aan school mogen worden doorgegeven

$G$ vraag of IVBO'er wil deelnemen aan vervolgonderzoek een half jaar later

0 naam en adres van de IVBO'er

\section{Bron: ROA}

Voor ieder onderwerp staat aangegeven of het om een vraag met gesloten antwoordcategorieën $(G)$ gaat of om een vraag met een open antwoordcategorie (0). De decanen hebben hun voorkeur uitgesproken voor gesloten vragen. Dit betekent wel dat gegeven antwoordcategorieën goed herkenbaar moeten zijn voor de schoolverlaters. Omdat men op voorhand nooit precies alle relevante antwoordcategorieën kan onderscheiden, zal bij een aantal gesloten vragen de categorie 'anders, namelijk ........ worden opgenomen. Daarnaast zijn er ook vragen met dusdanig veel potentiële antwoordmogelijkheden dat een open vraag overzichtelijker is. Dit geldt bijvoorbeeld voor de vragen naar het beroep of de branche waarin de schoolverlater werkzaam is of de opleiding die de IVBO'er is gaan volgen.

Of men kiest voor open of gesloten vragen hangt overigens ook nauw samen met de vraag of men kiest voor gegevensverzameling via een schriftelijke vragenlijst, een telefonische enquête of een interview (zie Segers, 1983). In een telefonische enquête kunnen geen vragen worden opgenomen met een groot aantal antwoordcategorieën (meer dan vijf). Een telefonische enquête leent zich het best voor ja-/neevragen en vragen waarop mensen snel en spontaan een antwoord kunnen geven. Het bijvoorbeeld aan de geënquéteerde vragen of deze even op het loonstrookje wil kijken wat zijn/haar bruto maandsalaris is, is bij deze vorm van dataverzameling niet 
werkbaar. In een schriftelijke vragenlijst is het wel mogelijk om vragen met meer dan vijf antwoordcategorieën op te nemen. Al moet men ook hier proberen het aantal antwoordcategorieën zo klein mogelijk te houden. Ook moet een vragenlijst vlot in te vullen zijn. Teveel gepuzzel en nadenkwerk verstoort het 'ritme' van het invullen en verlaagt de respons. Daarentegen is het bij een interview geen enkel probleem als een vraag tot enig denkwerk aanzet. De interviewer kan bovendien eventuele onduidelijkheden in de vraagstelling verhelderen, doch moet hierbij opletten dat hij/zij niet op de stoel gaat zitten van de geïnterviewde. De mate van voorstructurering van een interview bepaalt vaak het aantal zijsporen en de diepgang van het interview. In paragraaf 2.3 zal worden aangegeven op welke wijze de gegevens voor dit onderzoek het beste zouden kunnen worden verzameld.

Tabel 2.13b

Onderzoeksonderwerpen voor de uitgebreide bestemmingsmeting naar de positie op de arbeidsmarkt en in het vervolgonderwijs van (gediplomeerde) IVBO'ers

Uitgebreide meting: integraal deel

$G$ controlevragen over opleiding en leeftijd

$G$ nagaan of voorgedrukte gegevens over werkgever en/of vervolgopleiding (nog)correct zijn

0 totaal aantal maanden dat IVBO'er na opleiding werkloos is geweest

$G$ voornaamste bezigheid op enquêtemoment: leerlingwezen, scholier, betaaldwerk, onbetaald werk, huishouden, werkloos, militaire/vervangende dienstplicht, anders:

G algemene beoordeling van voorbereiding IVBO-opleiding op beroepspraktijk/vervolgopleiding

$G$ beoordeling van aspecten (deel van de populatie wordt dit voorgelegd)

0 waaraan meer aandacht schenken tijdens IVBO (deel van de populatie wordt dit voorgelegd)

$\mathrm{G}$ opnieuw zelfde opleiding kiezen (qua richting)

$G$ op zoek naar (ander) werk

$G$ voor minimaal 12 uur per week betaald werk willen hebben

$G$ als werkzoekende ingeschreven bij arbeidsbureau

$\mathrm{G}$ binnen 2 weken beschikbaar voor (ander) werk

$G$ vraag of ook niet-anonieme resultaten aan school mogen worden doorgegeven

0 naam en adres IVBO'er

Uitgebreide meting: deel werkenden

0 naam actueel beroep en korte omschrijving van de werkzaamheden

0 naam, branche en plaats van de organisatie waar men op dat moment werkt

G waarom gekozen voorwerk (evt. in combinatie opleiding) i.p.v. alleen (dag)opleiding?

0 wanneer in deze baan begonnen?

$G$ hoe aan baan gekomen (verwervingskanaal)?

G soort dienstverband (inclusief bijzondere regelingen als WSW, WetVermeend/Moor e.d.)

$\mathrm{G}$ aanstellingsduur

$G$ personeelsomvang bedrijf

$G$ minimaal vereiste opleidingsniveau

$G$ vereiste opleidingsrichting

0 wekelijkse arbeidsduur

0 (bruto) maandsalaris

Uitgebreide meting: deel verder lerenden

0 wanneer aan deze opleiding begonnen?

0 vervolgopleiding na verlaten IVBO: naam en plaats van opleiding en school

$G$ vraag of men deze opleiding nog volgt

\section{Bron: ROA}




\section{Stijl en lay-out}

Verder geven de decanen aan dat het belangrijk is dat de vragen in de RUBSenquête voor de IVBO'ers nu soms aan de moeilijke kant zijn of te weinig concreet. Het kleine lettertype kan voor deze groep met vaak leesmoeilijkheden eveneens problemen opleveren. De moeilijkheid zit ' $m$ enerzijds in de hoeveelheid toelichtingen bij de vragen. Anderzijds gaat het hier om de woordkeuze en de lengte van de vragen en/of antwoorden. Verder zijn de gehanteerde begrippen nogal eens te abstract voor de IVBO'ers of staan deze te ver af van hun leefwereld. De decanen gaven onder andere de volgende voorbeelden.

* De ruimte voor opmerkingen over de school, het werk, de vragenlijst e.d. nodigt niet uit tot het maken van opmerkingen hierover. Men zou bijvoorbeeld de vraag kunnen stellen: 'Vond je het leuk om deze vragenlijst in te vullen? Waarom wel of juist niet?'.

* De vraag: 'Hoe vind je de aansluiting tussen je opleiding van vorig jaar en je huidige bezigheden? (bijvoorbeeld je werk of opleiding)' is lastig te beantwoorden, aangezien deze schoolverlaters vaak niet weten wat met 'de aansluiting' wordt bedoeld. Het gaat hier om vakjargon dat de schoolverlater waarschijnlijk anders definieert dan de onderzoeker. Het is beter om die vraag om te zetten in: 'Heeft de school je goed voorbereid op je huidige bezigheden? (bijvoorbeeld je werk of opleiding).

* De vraag met betrekking tot het oordeel van de schoolverlater of aan de genoemde aspecten tijdens de IVBO-opleiding méér of minder aandacht moet worden besteed, kan eveneens eenvoudiger worden gesteld: 'Heeft de school je voldoende over onderstaande onderwerpen verteld?'.

Daarnaast is een aantal aspecten, volgens de decanen, te abstract en te weinig opleidingsspecifiek. Welke schoolverlater begrijpt dat 'warenkennis' tot de vaktheorie behoort? De decanen hebben overigens wel oog voor het vakkenoverstijgende karakter van de genoemde aspecten in de RUBS-enquête. Wanneer kan worden verwacht dat de schoolverlaters bepaalde begrippen niet kunnen hanteren, dan zouden deze begrippen niet moeten worden opnomen in de lijst. Eventueel zou een inlegvel kunnen worden gebruikt om vakspecifieke onderwerpen aan bod te laten komen. Hierbij moet wel worden gerealiseerd dat alleen al het IVBO tientallen verschillende vakrichtingen kent.

Een van de decanen wees er op dat er leerlingen zijn die de naam van de opleiding die wordt voorgedrukt op de RUBS-enquête niet herkennen als de door hen gevolgde opleiding. Het is (voor deze groep schoolverlaters) wellicht zinvol om niet alleen de opleiding voor te drukken op het vragenformulier, maar eveneens de school waaraan deze opleiding is gevolgd. Wanneer ook expliciet naar de naam en het 
adres van de schoolverlater wordt gevraagd, verwachten de decanen doorgaans geen lagere respons.

\section{Organisatie gegevensverzameling}

In het voorafgaande is de organisatie van de gegevensverzameling al een aantal keren ter sprake gebracht. De belangrijkste vraag die hierbij moet worden beantwoord is, via welk medium de informatie verzameld zou moeten worden. Zoals hierboven al is aangegeven kan men daarbij kiezen uit de volgende dataverzamelingstechnieken:

- interview;

- telefonische enquête;

- schriftelijke vragenlijst.

De keuze voor een van deze technieken of een combinatie daarvan is volgens Segers (1993) afhankelijk van de onderzoekssituatie, het onderzoekselement en van de eigenschappen waarover informatie wordt gewenst. Hierbij dient te worden bedacht dat niet de gevraagde eigenschap zelf wordt gemeten, maar de informatie die de respondent over deze eigenschap verstrekt. Bij het interview is de afstand tussen de te observeren eigenschap en de mededeling hierover het kleinst, bij een schriftelijke vragenlijst is deze afstand het grootst. Verder moet worden gestreefd naar een zo hoog mogelijke validiteit en betrouwbaarheid van het meetinstrument. De validiteit betreft de vraag of de theoretisch bedoelde eigenschappen inderdaad via de gekozen meting worden vastgesteld ('meten we wat we willen meten?'). Een meting wordt betrouwbaar genoemd wanneer bij herhaalde toepassing op dezelfde, onveranderende respondenten de meting hetzelfde resultaat oplevert (Segers, 1983). In het hieronder staande schema staat aangegeven op welke momenten tijdens de dataverzameling verrekeningen kunnen optreden (zie Galtung, 1967 in: Segers, 1983):

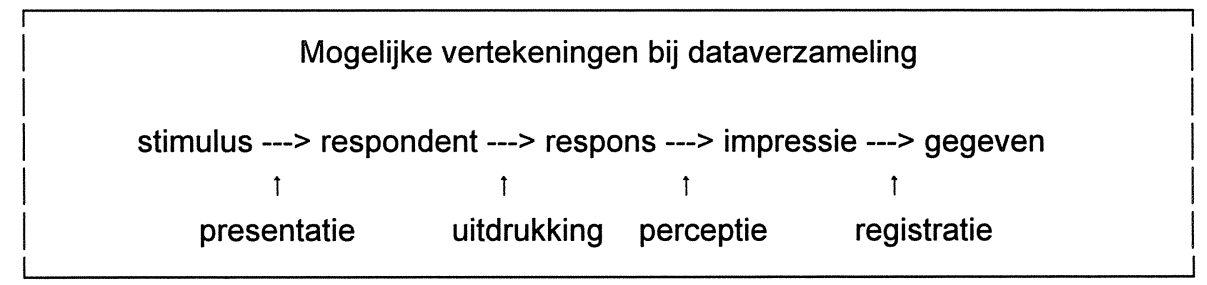

Bij de afweging voor een van de drie technieken, of een combinatie daarvan, zou men zich de volgende vragen moeten stellen.

* Wil men formele, kwantificeerbare of informele, beschrijvende informatie ontvangen? 
Deze keuze hangt direct samen met de vraag in hoeverre men de dataverzameling, zowel de vragen (stimuli) als antwoorden (reacties), wil en kan voorstructureren. Hoe flexibel moet het instrument zijn?

* Wie beantwoordt deze vragen? Sluit het gevraagde nauw aan bij de dagelijkse leefwereld van de respondent? Gaan deze vragen over hem-/haarzelf of over anderen?

* Welke techniek levert de hoogste respons op? Zijn respondenten goed te motiveren?

* Gaat het om feitelijke informatie of om de mening van de respondent over een bepaalde zaak? Kan deze informatie spontaan worden gegeven of moeten hiervoor gegevens worden opgezocht? Is een uitgebreide toelichting bij de vragen noodzakelijk? Vereist de gevraagde informatie veel denkwerk? In hoeverre kan subjectiviteit of beïnvloeding worden vermeden? In hoeverre is een check op de betrouwbaarheid van de gegevens mogelijk?

* Hoeveel informatie wordt gevraagd? Is het instrument geschikt voor de hoeveelheid gevraagde informatie?

* Gaat het om anonieme informatie? Zo niet, voldoet de dataverzameling aan de richtlijnen van de Wet persoonsregistraties? Hoe persoonlijk is de gevraagde informatie?

* Welke kosten zijn er aan het gebruik van de techniek verbonden bij de dataverzameling zelf en bij de verwerking van de gegevens? Zowel uitgedrukt in geld als in menskracht. Is deze menskracht aanwezig?

Met het oog op vergelijkingsmogelijkheden tussen RUBS en het IVBO-meetinstrument wordt voorgesteld om een meting synchroon plaats te laten vinden met het RUBS-onderzoek. Dit betekent dat een meting onder de gediplomeerden van het IVBO anderhalf jaar na diplomering uitgezet moet worden.

De meting zou formele, kwantificeerbare gegevens dienen op te leveren. Voor het grootste gedeelte betreft het feitelijke informatie. Bij de voorgestelde verkorte meting wordt informatie gevraagd die de IVBO'er spontaan kan geven. De uitgebreide meting bevat vragen die enige toelichting of denkwerk behoeven, of waarvoor aanvullende informatiebronnen moeten worden geraadpleegd (bijvoorbeeld bij het salaris). Het gevaar voor onbedoelde beïnvloeding is het kleinst bij het gebruik van een schriftelijke vragenlijst. 
Waar mogelijk zouden de vragen voorgestructureerd dienen te worden. Vragen waarop vele antwoorden mogelijk zijn, zoals beroep, branche en opleiding, dienen een open antwoordmogelijkheid te krijgen. Daarna worden deze gecodeerd in vooraf bepaalde categorieën (middels de door ROA gehanteerde beroepen-, branche- en opleidingenlijsten die zijn gebaseerd op CBS-classificaties).

De vragen worden beantwoord door de respondenten zelf, al kan wel expliciet worden aangegeven dat zij ouders, docenten en eventueel hun werkgever kunnen inschakelen voor hulp. De vragen hebben zoveel mogelijk betrekking op de situatie op het enquêtemoment. Retrospectieve vragen worden zoveel mogelijk vermeden. Aangezien ook vragen in het onderzoek zijn opgenomen waardoor het traceren van individuele personen mogelijk wordt, is het verstandig om een zogenaamd beheersen gebruiksreglement voor de onderzoeksgegevens op te stellen en om dit onderzoek aan te melden bij de Registratiekamer in het kader van de Wet persoonsregistraties. Verder leeft bij scholen de wens om ook niet-anonieme informatie te verkrijgen. Daarom is het nodig dat hiervoor toestemming wordt gevraagd aan de schoolverlaters.

Over het algemeen levert een telefonische enquête de hoogste respons op. Verder is de respons op een interview doorgaans hoger dan die op een schriftelijke vragenlijst (zie Segers, 1983). De respons is echter niet alleen afhankelijk van de gehanteerde dataverzamelingstechniek, maar eveneens van de context waarin de data worden verzameld. Zo kan de respons worden verhoogd wanneer de verkorte meting telefonisch wordt afgenomen door docenten van het IVBO, of het (verkorte of uitgebreide) vragenformulier wordt begeleid door een brief van de betreffende IVBOschool. Ook kan het afnemen van een interview of het invullen van een schriftelijke vragenlijst worden gecombineerd met een 'terug-kom-dag' voor de schoolverlaters. Het in het examenjaar bespreken van voorgaande onderzoeksresultaten met de IVBO'ers is eveneens een goede manier om het onderzoek alvast 'in de week te zetten'. Het is belangrijk om het onderzoek zo op te zetten dat de IVBO'ers gemotiveerd zijn om aan het onderzoek deel te nemen.

Wat de kosten betreft, kan worden gesteld dat het verzamelen, verwerken en analyseren van gegevens die middels een schriftelijke vragenlijst zijn gegenereerd het goedkoopst is, en middels een interview het duurst. Een interview kost ook de meeste menskracht, zowel in de fase van dataverzameling als in de fasen van dataverwerking en analyse. Het verzamelen van informatie via een telefonische enquête kost meer geld en menskracht dan via een schriftelijke vragenlijst, maar het verwerken van deze telefonisch verkregen gegevens is wel goedkoper en sneller. De kosten voor de analyse hiervan zijn vergelijkbaar met de analysekosten die een schriftelijke vragenlijst met zich mee brengt. 
Gegeven bovenstaande argumenten en de omvang van de voorgestelde alternatieven voor de enquête, kan de verkorte meting zowel via een schriftelijke als via een telefonische enquête plaatsvinden. Een schriftelijke vragenlijst is het meest geschikt voor het (uitgebreidere) alternatief waarbij de RUBS-vragenlijst als voorbeeld dient. Het integraal interviewen van de totale groep schoolverlaters van het IVBO wordt, met het oog op met name de benodigde informatie en de verhoudingsgewijs hoge kosten, ontraden. Het kan desalniettemin bijzonder zinvol zijn om, bijvoorbeeld aan de hand van de onderzoeksresultaten, een aantal schoolverlaters te interviewen om het 'verhaal achter de cijfers' te kennen. Deze schoolverlaters kunnen hiervoor in groepsverband of individueel worden benaderd. Een peiling of men hieraan wil deelnemen kan eventueel in de vragenlijst worden opgenomen.

Eén van de decanen gaf aan dat zijn voorkeur uitging naar een telefonische enquêtering. De andere decanen zijn van mening dat het beste een schriftelijke vragenlijst kan worden gebruikt. De argumenten die zij hiervoor aandroegen waren de volgende. Bij een schriftelijke vragenlijst is het meest duidelijk wat wel en niet wordt gevraagd. En de schoolverlaters kunnen zelf uitmaken op welk moment zij deze vragenlijst willen invullen. De schoolverlaters kunnen daarbij eventueel anderen raadplegen.

Op één van de drie bezochte scholen behoort één op de drie leerlingen tot de allochtonen. Hoewel een deel van deze groep moeite heeft met het begrijpen van de Nederlandse taai, acht de betreffende decaan het niet nodig een enquête voor deze groep te vertalen. Mits de vragen op eenvoudige wijze zijn gesteld (Dit kan voor de autochtonen ook geen kwaad!). Het telefonisch benaderen van deze groep leerlingen vindt de desbetreffende decaan minder geschikt.

Ten slotte gaf een van de decanen aan dat een telefonische enquête door de IVBOdocenten misschien wel een aardig idee is, maar dat hij niet verwacht dat de - vaak al overvraagde - docenten hieraan zouden deelnemen. Met name omdat een dergelijke telefonische enquête's avonds afgenomen zou moeten worden. 



\section{Voortgezet speciaal onderwijs}

\subsection{Afbakening onderzoekspopulatie}

"Verwijzing naar het speciaal onderwijs, en met name naar het MLK-onderwijs blijkt, naast het intelligentieniveau en de leerachterstand, veelal gekoppeld te zijn aan het sociale milieu en de mate waarin ze lastig gedrag vertonen. MLK-jongeren komen, naar verhouding, het meest voor in sociaal-economisch gezien de laagste milieu's" (Roes, 1993). Daarnaast wordt een aantal allochtone kinderen ten onrechte naar het speciaal onderwijs gestuurd. Uit een promotie-onderzoek aan de Faculteit Sociale Wetenschappen van de Universiteit Utrecht is namelijk gebleken dat ruim een kwart van de Turkse en Marokkaanse kinderen, die bij een intelligentietest als zwakbegaafd werden geclassificeerd, bij een speciaal ontworpen leertest voor etnische minderheden gemiddeld of zelfs bovengemiddeld blijken te scoren. De reden hiervoor is dat intelligentietests vaak niet of minder geschikt zijn voor kinderen uit andere culturen (Universiteit Utrecht, 1993).

Het volgende citaat geeft een indruk van de tekorten waarmee deze schoolverlaters beschikbaar komen voor de arbeidsmarkt.

"De gevoelens van onzekerheid, het negatieve zelfbeeld, het afwezig zijn van een duidelijk zelfbewustzijn, de onmogelijkheid om de wereld om zich heen en hun eigen leven structuur te geven en een slecht sociaal inzicht, zijn de meest opvallende tekorten waarmee deze jongeren kampen".

"Deze groep, veelal gemotiveerde jongeren, gaat zonder begeleiding behoren tot de harde kern van werklozen. En dat terwijl deze groep jongeren voor de arbeidsmarkt de geschikte groep is voor de invulling van vacatures die eenvoudig, routinematig en veelal handmatig van aard zijn" (Roes, 1993).

Uit een landelijke inventarisatie van VSO-projecten, verricht door het Landelijk Overleg Werkloosheid in opdracht van het Ministerie van Sociale Zaken en Werkgelegenheid kwam naar voren dat er in Nederland in totaal 108 (veelal tijdelijke) projecten zijn ontstaan met als primaire doel VSO-schoolverlaters middels (individuele) trajectbegeleiding toe te leiden naar de arbeidsmarkt (Verkuijlen, 1993). Zo is in augustus 1992 vanuit SOMMA, de overkoepelende organisatie vanSociaal-Pedagogische Diensten (SPD's), gestart met een driejarig landelijk arbeidsintegratie-project. Dit project heeft als doel om de betere MLK-schoolverlaters middels ondersteuning van arbeidsconsulenten binnen de SPD's te plaatsen in het vrije bedrijfsleven.

In het schooljaar 1993194 volgen bijna 114.000 leerlingen basis en voortgezet speciaal onderwijs in Nederland. Tabel 3.1 geeft een overzicht van de aantallen scholieren die jaarlijks in Nederland het (v)so verlaten. In de tabel komt naar voren dat er in de loop van de negentiger jaren een verdere toename wordt verwacht met betrekking tot de landelijke uitstroom uit het speciaal onderwijs. 
Tabel 3.1

Aantallen schoolverlaters (V)SO, 1990/91-2000/01

\begin{tabular}{lc}
\hline Studiejaar & Aantal \\
\hline & \\
$1990 / 91$ & 8.646 \\
$1991 / 92$ & 8.822 \\
$1992 / 93$ & 8.869 \\
$1993 / 94$ & 9.370 \\
$1994 / 95$ & 9.293 \\
$1995 / 96$ & 9.799 \\
$1996 / 97$ & 10.124 \\
$1997 / 98$ & 10.286 \\
$1998 / 99$ & 10.351 \\
$1999 / 00$ & 10.399 \\
$2000 / 01$ & 10.506 \\
\hline
\end{tabular}

Bron: Ministerie van Onderwijs en Wetenschappen (1993)

Binnen het VSO kunnen de volgende vormen worden onderscheiden:

- VSO voor Leer- en Opvoedingsmoeilijkheden (VSO-LOM);

- VSO voor Moeilijk Lerende Kinderen (VSO-MLK);

- VSO voor Zeer Moeilijk Lerende Kinderen (VSO-ZMLK);

- VSO voor Zeer Moeilijk Opvoedbare Kinderen (VSO-ZMOK).

Daarnaast zijn er nog het (V)SO-MYTYL als speciale onderwijsvoorziening voor lichamelijk gehandicapten en (V)SO-TYLTYL als speciale onderwijsvoorziening voor meervoudig gehandicapten (lichamelijke én verstandelijke handicap).

VSO-scholen weten waar al hun leerlingen, direct na het verlaten van de school terecht komen. Voor het meten van de eerste bestemming zouden derhalve de scholen als informatiebron kunnen worden gebruikt. Hiervoor zou een standaardvragenformulier, dat voor alle scholen gelijk is, kunnen worden ontwikkeld. De bereidheid van scholen om hun medewerking te verlenen, zou kunnen worden vergroot indien zij via de overkoepelende organisaties worden benaderd met het verzoek om in het monitoringsysteem te participeren.

Overigens staan de personen waarmee gesprekken zijn gevoerd, positief ten opzichte van een systematische registratie van de latere bestemming van VSOschoolverlaters. Scholen geven aan dat zij hun onderwijs beter op de arbeidsmarkt kunnen afstemmen op basis van inzicht in de latere bestemming van hun schoolverlaters. Instanties die VSO-schoolverlaters begeleiden bij hun toetreding naar de arbeidsmarkt kunnen inzicht in de latere bestemming hanteren als mogelijkheid om hun maatregelen te evalueren.

Bij de selectie van de groepen schoolverlaters die voor onderzoek naar de latere bestemming in aanmerking komen, zouden de aantallen schoolverlaters van de desbetreffende categorieën van het VSO als criterium kunnen worden gehanteerd. 
Welnu, qua aantallen schoolverlaters is de landelijke uitstroom uit het VSO als volgt over de schooltypen verdeeld.

Tabel 3.2

VSO-schoolverlaters naar schooltype

\begin{tabular}{ll} 
LOM & circa $38 \%$ \\
MLK & circa $38 \%$ \\
ZMLK & circa $8 \%$ \\
ZMOK + MYTYL + TYLTYL & circa $15 \%$ \\
\hline Bron: P. Verkuilen (coördinator VSO-MLK, Landelijk Overleg Werkloosheid)
\end{tabular}

Wanneer de omvang van de uitstroomcategorieën als criterium voor de selectie van de onderzoekspopulatie wordt gehanteerd, dan zou het onderzoek naar de latere bestemming zich kunnen beperken tot schoolverlaters van het VSO-LOM en het VSO-MLK.

Echter, niet alleen vanwege hun relatief kleine aantallen schoolverlaters, maar ook omdat schoolverlaters van VSO-ZMLK-scholen en van MYTYL- en TYLTYL-scholen vrijwel nooit beschikbaar komen voor de reguliere arbeidsmarkt, lijkt het niet voor de hand liggend om deze categorieën schoolverlaters in een monitoringsysteem op te nemen. Immers:

- ZMLK-schoolverlaters komen in meerderheid terecht in gezinsvervangende tehuizen/dagverblijven voor geestelijk gehandicapten;

- MYTYL- en TYLTYL-schoolverlaters zijn nauwelijks relevant voor bestemmingsonderzoek middels enquêtes omdat deze groep schoolverlaters in meerderheid geregistreerd wordt door GMD'S.

Van deze categorieën schoolverlaters komen alleen de besten in aanmerking voor plaatsing op de wachtlijst voor een Sociale Werkplaats.

ZMOK-schoolverlaters zijn nauwelijks interessant om in een monitoring systeem te worden opgenomen, niet alleen vanwege hun relatief kleine aantallen maar ook vanwege de te verwachten uiterst lage respons en vanwege hun, in arbeidsmarkttermen gesproken, grote mobiliteit. $\mathrm{Zij}$ komen zelden in een reguliere arbeidsplaats terecht, vallen vaak onder kortlopende speciale opvangsregelingen, en zijn bijgevolg geografisch zeer mobiel en moeilijk op te sporen. Door éen gesprekspartner is ZMOK dan ook getypeerd als 'Zeer Moeilijk Op te sporen Kinderen'. De bereidheid om aan onderzoek mee te werken, zowel bij schriftelijke of telefonische benadering als bij mondelinge interviews is uiterst gering. Vanwege de moeilijke traceerbaarheid en de geringe bereidheid om aan onderzoek mee te werken, is de respons uiterst laag. Daarbij komt dat een eenmalige meting, bijvoorbeeld één jaar na schoolverlaten, vanwege de zeer grote mobiliteit qua bestemming weinig zinvol is, want de kans is erg groot dat de bestemming een week later een geheel andere is. Voor deze categorie schoolverlaters zou het volgen over een langere tijdspanne (in kaart 
brengen van 'gaten' in cv) zinvoller zijn. Het probleem van de uiterst geringe motivatie om aan onderzoek mee te werken blijft echter onverminderd bestaan. De geringe bereidheid geldt overigens ook voor de ouders. Een alternatieve benadering zou kunnen zijn om de bestemming via de administraties van organisaties als SPD's, GAK's en GMD's te achterhalen.

Gezien de bovengenoemde overwegingen zou de meting van de latere bestemming zich, zoals reeds gezegd, kunnen beperken tot het VSO-LOM en het VSO-MLK.

Zoals eerder is vermeld, zijn er in de afgelopen jaren in Nederland in totaal 108 (veelal tijdelijke) regionale projecten ontstaan met als primaire doel VSO-schoolverlaters middels (individuele) trajectbegeleiding toe te leiden naar de arbeidsmarkt. Als gevolg hiervan zijn er soms enorme regionale verschillen in de mate waarin VSOschoolverlaters erin slagen om een plaats op de (reguliere) arbeidsmarkt te verwerven. Een integrale meting verdient derhalve de voorkeur boven een steekproefsgewijze meting. Dit geldt zowel voor de eerste meting bij scholen als voor de latere meting onder schoolverlaters.

Met betrekking tot de afbakening van de onderzoekspopulatie resteert de vraag of het onderzoek zich zou moeten beperken tot gediplomeerde schoolverlaters, of dat ook ongediplomeerde schoolverlaters in het onderzoek zouden moeten worden meegenomen. Uit onderzoek onder VSO-schoolverlaters in Noord-Brabant is naar voren gekomen dat de arbeidsmarktintrede bij gediplomeerden minder problematisch verloopt dan bij ongediplomeerde schoolverlaters. Gezien de variatie bij de arbeidsmarktintrede tussen beide categorieën schoolverlaters zou het onderzoek gediplomeerde en ongediplomeerde schoolverlaters kunnen omvatten.

Tabel 3.3 geeft een overzicht van de bestemming, direct na het verlaten van de school, van alle schoolverlaters van het VSO in de provincie Limburg in de schooljaren 1989/90, 1990/91 en 1991/92. De gegevens zijn afkomstig uit een onderzoek, uitgevoerd door het RDC-Limburg, waaraan alle 11 VSO-MLK-scholen en 7 van de 8 VSO-ZMOK-scholen in Limburg hebben meegewerkt.

Met betrekking tot het VSO-MLK laat tabel 3.3 zien dat het bestemmingspatroon over de drie beschouwde cohorten nauwelijks varieert. Ongeveer de helft komt terecht op de arbeidsmarkt (een kwart in de Sociale Werkvoorziening, en slechts een vijfde op de reguliere arbeidsmarkt). Zo'n $14 \%$ gaat verder onderwijs volgen, circa $17 \%$ wordt opgevangen in speciale projecten, terwijl eveneens circa $17 \%$ thuis zit.

Met betrekking tot het VSO-ZMOK laat tabel 3.2 zien dat ongeveer de helft van de schoolverlaters in Limburg doorstroomt naar verder onderwijs. Slechts één op tien schoolverlaters heeft de reguliere arbeidsmarkt als bestemming. 'Het meest opval- 
lend is de toename van het aantal schoolverlaters waarvan de bestemming onbekend is' (RDC-Limburg, 1993).

Tabel 3.3

Bestemming VSO-schoolverlaters in Limburg, 1989190-1991192

\begin{tabular}{|c|c|c|c|c|c|c|}
\hline & $\begin{array}{l}\text { VSO-M } \\
89 / 90\end{array}$ & $\begin{array}{l}\text { LK } \\
90 / 91\end{array}$ & $91 / 92$ & $\begin{array}{l}\text { VSO-Z } \\
89 / 90\end{array}$ & $\begin{array}{l}\text { MOK } \\
90 / 91\end{array}$ & $91 / 92$ \\
\hline $\begin{array}{l}\text { Sociale Werkvoorziening } \\
\text { Vrije bedrijf }\end{array}$ & $\begin{array}{l}23 \\
19\end{array}$ & $\begin{array}{l}30 \\
21\end{array}$ & $\begin{array}{l}27 \\
18\end{array}$ & $\begin{array}{l}2 \\
8\end{array}$ & 8 & $\overline{9}$ \\
\hline $\begin{array}{l}\text { VSO elders } \\
\text { IBO/LBO } \\
\text { MBO } \\
\text { MAVO/HAVO }\end{array}$ & $\begin{array}{r}10 \\
4 \\
- \\
-\end{array}$ & $\begin{array}{r}10 \\
3 \\
- \\
-\end{array}$ & $\begin{array}{l}9 \\
6 \\
- \\
-\end{array}$ & $\begin{array}{r}21 \\
27 \\
4 \\
7\end{array}$ & $\begin{array}{r}16 \\
24 \\
2 \\
5\end{array}$ & $\begin{array}{r}19 \\
23 \\
2 \\
3\end{array}$ \\
\hline $\begin{array}{l}\text { Scholingstrajecten } \\
\text { Vormingscentrum } \\
\text { VSO-schoolverlatersprojectl } \\
\text { ieugdwerkgarantiewet }\end{array}$ & $\begin{array}{l}6 \\
5 \\
4\end{array}$ & $\begin{array}{r}11 \\
5 \\
2\end{array}$ & $\begin{array}{r}10 \\
6 \\
3\end{array}$ & $\begin{array}{l}8 \\
4\end{array}$ & $\begin{array}{l}7 \\
4 \\
-\end{array}$ & $\begin{array}{l}9 \\
3 \\
-\end{array}$ \\
\hline Thuis & 23 & 15 & 14 & 3 & 3 & 4 \\
\hline Overig* & 7 & 4 & 7 & 15 & 30 & 28 \\
\hline Totaal N (= 100\%) & 210 & 227 & 220 & 183 & 206 & 185 \\
\hline
\end{tabular}

* waaronder internaat, Dagverblijf voor Ouderen, militaire dienst, onbekend Bron: RDC-Limburg (1993)

\subsection{Meting van de eerste bestemming}

Om drie redenen wordt een monitoringinstrument á la RUBS minder geschikt geacht voor het meten van de bestemming van VSO-schoolverlaters. In de eerste plaats vanwege het lage abstractieniveau en de beperkte taalvaardigheid van de schoolverlaters, waardoor een dergelijke uitgebreide schriftelijke bevraging niet of minder geschikt is. Daarbij komt dat de variatie in verstandelijke en taalkundige vermogens binnen deze categorieën schoolverlaters dermate groot is, dat meerdere varianten van een schriftelijke vragenlijst nodig zouden zijn voor een betrouwbare meting. Bij RUBS vindt ieder jaar één meting plaats ongeveer anderhalf jaar na schoolverlaters. Toepassing van deze systematiek onder VSO-schoolverlaters zou impliceren dat de tijdspanne tussen het moment van schoolverlaters en het moment van enquêteren te zeer zou variëren, aangezien VSO-leerlingen de school niet klassikaal op het einde van het schooljaar verlaten, maar individueel op verschillende tijdstippen.

Hieronder wordt nader ingegaan op de bovengenoemde redenen waarom RUBS voor VSO-schoolverlaters minder geschikt wordt geacht. Daarmee samenhangend worden de contouren geschetst van een alternatief monitoringinstrument voor het VSO. 
In de vorige paragraaf is er al op gewezen dat de VSO-scholen als informatieverstrekkers kunnen fungeren bij het meten van de bestemming direct na het verlaten van de school, aangezien deze eerste bestemming bij de VSO-scholen bekend is. Voor het meten van de eerste bestemming zou een standaardformulier kunnen worden ontwikkeld dat voor alle scholen hetzelfde is. Op deze wijze kan uniformiteit met betrekking tot de dataverzameling worden gewaarborgd. Op dit formulier zou eerst een aantal gegevens over de school moeten worden ingevuld, waaronder de naam en het adres van de school, het type VSO dat wordt aangeboden, en de naam en het telefoonnummer van degene die het vragenformulier heeft ingevuld. Vervolgens een lijst van de leerlingen die in het afgelopen school- of kalenderjaar de school hebben verlaten, waarop per schoolverlater een aantal gegevens worden vermeld, waaronder:

persoonskenmerken

- geslacht, geboortedatum, etniciteit

- naam, adres, postcode, woonplaats en telefoonnummer van schoolverlater en van ouders/verzorgers

opleidingsgegevens

- naam van de opleiding

- studiejaar/klas aanvang opleiding

- naam, branche en plaats van de organisatie waar stage is gelopen

- laatst gevolgde studiejaar/klas

- wel/geen diploma

- datum schoolverlaters

eerste bestemming na het verlaten van de school

- indien vervolgopleiding: type vervolgopleiding en naam en lokatie vervolgschool

- indien werk: al dan niet reguliere arbeidsplaats, beroep en naam, branche en plaats van de organisatie.

Voor het welslagen van een op te zetten monitoringsysteem is het van het grootste belang dat de desbetreffende scholen aan het onderzoek meewerken. De bereidheid van scholen om hun medewerking te verlenen, zou kunnen worden vergroot indien zij via de overkoepelende organisaties worden benaderd met het verzoek om in het monitoringsysteem te participeren. De bereidheid om ieder jaar opnieuw te participeren, zou kunnen worden bevorderd door de scholen jaarlijks een tabel te verstrekken waarin op basis van de vorige keer verstrekte gegevens de bestemming van 'eigen' schoolverlaters kan worden vergeleken met de desbetreffende landelijke cijfers. 


\subsection{Meting van de latere bestemming}

Te verzamelen gegevens

Bij het verkrijgen van inzicht in de latere bestemming van VSO-schoolverlaters gaat het om de volgende kerngegevens.

Voornaamste bezigheid op moment van enquêteren:

- beschikbaar voor arbeidsmarkt (betaald werk, werkzoekend, op de wachtlijst voor een plaats in bijvoorbeeld de Sociale Werkvoorziening);

- niet beschikbaar voor arbeidsmarkt (verder onderwijs, militaire dienst, etc.).

Indien thans werkend:

- al dan niet reguliere arbeidsplaats;

- beroep en soort werkzaamheden;

- naam, branche en plaats van de organisatie.

Indien thans onderwijs volgend:

- type vervolgopleiding en naam en lokatie vervolgschool.

Anonimiteit:

- vraag of de verstrekte gegevens ook in niet-anonieme vorm aan school mogen worden doorgegeven (VSO-scholen zijn met name op het niveau van individuele leerlingen in de latere bestemming na schoolverlaters geïnteresseerd).

\section{Meetmoment}

Bij het vaststellen van het moment waarop de latere bestemming na schoolverlaters het beste kan worden gemeten, dient rekening te worden gehouden met het gegeven dat VSO-scholen op de hoogte zijn van de eerste bestemming van hun exleerlingen. Dit betekent dat van de VSO-schoolverlaters die:

- doorstromen naar vervolgonderwijs (bij LOM-schoolverlaters is dit tweederde deel) bekend is welk type vervolgonderwijs wordt gevolgd;

- niet doorstromen naar vervolgonderwijs (bij MLK-schoolverlaters is dit tweederde deel) bekend is welke hun eerste bestemming is.

Het is daarom zinvol om de meting van de latere bestemming, net als bij RUBS, plaats te laten vinden anderhalf jaar na het verlaten van de school. Bij de schoolverlaters die doorstromen naar verder onderwijs kan dan worden vastgesteld of zij na het eerste leerjaar van de vervolgopleiding zijn over gegaan naar het tweede leerjaar. Deze informatie is met name relevant voor LOM-scholen, waarbij tweederde van de schoolverlaters doorstromen naar verder onderwijs. Bij de schoolverlaters die zich aanbieden op de arbeidsmarkt wordt inzicht verkregen in het verloop van de loopbaan ná eventuele ondersteuning bij de toeleiding naar de arbeidsmarkt (zoals gezegd zijn er in Nederland legio projecten waarbij VSO-schoolverlaters middels individuele trajectbegeleiding worden toegeleid naar de arbeidsmarkt). Mede op 
basis van dit inzicht in de latere bestemming kunnen de instanties die VSO-schoolverlaters begeleiden bij hun toetreding naar de arbeidsmarkt. hun maatregelen evalueren.

Om de latere bestemming op enig moment na schoolverlaters, bijvoorbeeld na 18 maanden te bepalen is overigens niet zonder problemen aangezien de datum van schoolverlaten per leerling verschilt. VSO-leerlingen verlaten namelijk niet klassikaal de school op het einde van het schooljaar, maar individueel. Om de tijdspanne tussen het moment van schoolverlaters en het moment van de dataverzameling niet te veel te laten varieren tussen de schoolverlaters, zouden idealiter jaarlijks twee metingen kunnen plaatsvinden. Degenen die in de eerste helft van een bepaald kalenderjaar uitstromen, zouden in maart/april van het tweede daaropvolgende jaar kunnen worden benaderd. Bij leerlingen die in de tweede helft van een bepaald kalenderjaar uitstromen, zou de meting in september/oktober van het tweede daaropvolgende jaar kunnen plaatsvinden. Uit praktische overwegingen zou eventueel ook kunnen worden volstaan met één meting per jaar. Aansluiting bij RUBS zou betekenen dat dit meetmoment plaatsvindt in het najaar.

\section{Wijze van dataverzameling}

In paragraaf 3.1 is aangegeven dat het uitstroom- en bestemmingsonderzoek zich zou kunnen richten op schoolverlaters van VSO-LOM-scholen en VSO-MLK-scholen. Beide doelgroepen zijn behept met problemen, die vergaande consequenties hebben voor een op te zetten systeem van dataverzameling. Deze groepen schoolverlaters schamen zich vaak voor hun speciale opleidingsachtergrond en willen hier liever niet aan worden herinnerd. Dit komt de bereidheid om aan het onderzoek mee te werken niet ten goede. Daarnaast zijn het geringe abstractievermogen en de geringe taalvaardigheid problematisch voor de dataverzameling. Voor allochtone schoolverlaters komt daar nog bij de vaak zeer gebrekkige beheersing van de Nederlandse taal. Deze problemen hebben vergaande implicaties voor een op te zetten systeem van dataverzameling, zowel wat de vorm van de bevraging (schriftelijke enquête, telefonische enquête of mondeling interview) als de informatieverstrekkers (oud-leerlingen zelf of ouders/verzorgers) betreft.

Idealiter zou de dataverzameling kunnen bestaan uit een mondeling of telefonisch interview onder de schoolverlaters dat gehouden wordt door iemand die zij kennen en vertrouwen, bijvoorbeeld hun vroegere stagedocent. Dit zou niet alleen de respons ten goede komen maar ook de mogelijkheid bieden om indien nodig ter plekke vragen te kunnen toelichten. Vanwege de hoge kosten en omwille van de praktische uitvoerbaarheid vormt een mondeling interview echter geen haalbare kaart. Ook een telefonische enquête door vroegere stagedocenten lijkt moeilijk realiseerbaar, aangezien deze in de avonduren zou moeten plaatsvinden en stagedocenten hiervoor geen taakuren ter beschikking hebben. Een uitgebreide 
schriftelijke bevraging van de schoolverlaters á la RUBS wordt, vanwege het lage abstractieniveau en de beperkte taalvaardigheid niet of minder geschikt geacht. Daarbij komt dat de variatie in verstandelijke en taalkundige vermogens binnen deze categorieën schoolverlaters dermate groot is, dat meerdere varianten van een schriftelijke vragenlijst nodig zouden zijn voor een betrouwbare meting. Een pragmatische benadering van deze problemen zou kunnen zijn om niet de schoolverlaters zelf maar hun ouders of verzorgers te enquêteren. Dit impliceert wel dat evaluatieve vragen over de gevolgde VSO-opleiding niet kunnen worden gesteld. Vanwege een zo hoog mogelijke respons zou de enquête zo kort en eenvoudig mogelijk moeten zijn. Deze enquête kan beknopt worden gehouden aangezien persoonsgegevens en opleidingsgegevens reeds door de school zijn verstrekt bij de meting van de eerste bestemming. Verder zou de enquête moeten worden geïntroduceerd met een brief van de desbetreffende VSO-LOM-schoolNSO-MLKSCHOOL. In de begeleidende brief bij de enquête zou een telefoonnummer van de school kunnen worden vermeld, waar men nadere informatie over het onderzoek en het invullen van de vragenlijst kan krijgen. De enquête onder de ouders/verzorgers zou schriftelijk of telefonisch kunnen worden afgenomen. Een te houden proefonderzoek zou moeten uitwijzen welke wijze van benadering tot de hoogste respons (zowel overall als per vraag) leidt. Vanwege mogelijke selectiviteit in de respons, dient de enquête onder ouders/verzorgers in ieder geval te worden aangevuld met een non-respons onderzoek.

\section{Resumé}

Een monitoringsysteem voor het meten van de bestemming van VSO-schoolverlaters zou kunnen bestaan uit twee meetinstrumenten. Met behulp van het eerste instrument, een standaardformulier voor VSO-scholen, kan een aantal persoonskenmerken en opleidingsgegevens alsmede de eerste bestemming van VSO-schoolverlaters worden gemeten. Daartoe worden de scholen verzocht om een lijst van schoolverlaters te verstrekken, waarop de school voor iedere schoolverlater een aantal persoonsgegevens, opleidingsgegevens en gegevens over de eerste bestemming dient te vermelden. Met behulp van het tweede instrument, een beknopte schriftelijke of telefonische enquête onder ouders/verzorgers, kan voor LOM-en MLK-schoolverlaters de bestemming na anderhalf jaar worden gemeten. 



\section{Voorstel voor proefmeting}

\subsection{IVBO}

Dit hoofdstuk beschrijft het voorstel voor een proefmeting onder schoolverlaters van het IVBO en VSO, zoals dat op basis van het vooronderzoek voor de opdrachtgever is opgesteld. Naar aanleiding van het hieronder beschreven voorstel heeft de opdrachtgever besloten om een proefmeting te laten verrichten onder schoolverlaters van het IVBO. De opzet en resultaten van de uitgevoerde proefmeting staan beschreven in deel 2 van dit rapport.

In deze paragraaf wordt het voorstel geformuleerd voor de opzet van een proefonderzoek naar de uitstroom en bestemming van schoolverlaters van het IVBO. Dit voorstel is in de eerste plaats gebaseerd op vakliteratuur en de gesprekken die met een aantal decanen van (i)VBO-scholen zijn gevoerd omtrent de randvoorwaarden voor het ontwikkelen van een dergelijk instrument (zie paragraaf 2.3). Ten tweede zijn de uitkomsten van de respons- en invulanalyse, evenals de onderzoeksresultaten die zijn ontleend aan de RUBS-enquête, bij het opstellen van dit voorstel benut (zie paragraaf 2.2).

\section{Onderzoekspopulatie}

Mede gezien de lage respons onder de ongediplomeerde schoolverlaters zouden alleen de gediplomeerde schoolverlaters bij het proefonderzoek moeten worden betrokken. De verhouding tussen kosten en opbrengst is bij de groep ongediplomeerde schoolverlaters namelijk bijzonder ongunstig.

Om een goed beeld te krijgen van de mogelijkheden van een IVBO-opleiding op de arbeidsmarkt en in het vervolgonderwijs zou het ook niet juist zijn, dit beeld mede te laten bepalen door de resultaten van de ongediplomeerde schoolverlaters. Bij de ongediplomeerde schoolverlaters is immers niet duidelijk in hoeverre de door hen ingenomen positie op de arbeidsmarkt of in het vervolgonderwijs is toe te schrijven aan de door hen deels gevolgde, doch niet afgeronde opleiding. Het buiten beschouwing laten van de ongediplomeerde schoolverlaters in dit onderzoek heeft verder als voordeel dat een meting die in een bepaalde periode plaatsvindt, voor de gehele groep gediplomeerden eenzelfde afstudeerduur inhoudt. De gediplomeerden hebben namelijk allemaal, herexamens daargelaten, het diploma in dezelfde periode behaald. Ongediplomeerden verlaten gedurende het gehele studiejaar de opleiding. Hierdoor gaat de bij de gediplomeerden min of meer eenduidige relatie tussen enquêtemoment en afstudeerduur voor de ongediplomeerden niet op.

De scholen vinden het echter wel van belang om te weten wat er na het voortijdig verlaten van de school met de betreffende oud-leerling is gebeurd. Voorgesteld 
wordt derhalve om een instrument voor het meten van de uitstroom en bestemming van ongediplomeerde schoolverlaters te laten integreren met projecten die in het kader van het drop-out vraagstuk zijn opgezet.

Voor het proefonderzoek worden de IVBO'ers zelf benaderd. Het kan wel zinvol zijn de IVBO'ers expliciet te wijzen op mogelijke hulp van ouders, de werkgever, docenten e.d.

\section{Achtergrondinformatie via de schooladministratie}

Alvorens de feitelijke metingen onder de schoolverlaters van het IVBO uit te voeren, is het verstandig dat de schooladministraties vóóraf informatie verstrekken over een aantal achtergrondvariabelen. De vragenlijst kan hierdoor aanmerkelijk worden verkort en de vraagstelling en organisatie kan aan deze vooraf verstrekte informatie worden aangepast. Ten behoeve hiervan zal een informatieschema worden opgesteld aan de hand waarvan de schooladministratie en/of de decaan de benodigde gegevens over de IVBO'ers kan noteren.

\section{Alternatieven voor bestemmingsmeting}

Zoals hierboven reeds is uiteengezet, zou het proefonderzoek moeten worden benut om de volgende alternatieve dataverzamelingsinstrumenten te toetsen:

- verkorte schriftelijke vragenlijst (onderwerpen: zie tabel 2.13a);

- korte telefonische enquête (onderwerpen: zie tabel 2.13a);

- uitgebreide schriftelijke vragenlijst conform RUBS (onderwerpen: zie tabel 2.13b).

Het doel van het proefonderzoek is namelijk om na te gaan welke dataverzamelingsmethode in de praktijk het beste functioneert. Daarom wordt voorgesteld om bij één school de verkorte meting via een telefonische enquête te laten plaatsvin- den, terwijl een andere school de schoolverlaters met een korte vragenlijst (een soort antwoordkaart) benadert. Bij de school waarvan de schoolverlaters middels een telefonische enquête worden benaderd, zullen de IVBO-docenten worden ingeschakeld. Deze docenten beslissen of het in voorkomende gevallen noodzakelijk is om voor de allochtone schoolverlaters een tolk in te schakelen. Eventueel kan bij een deel van de laatste groep worden nagegaan wat het effect is op de respons van een telefonische oproep aan degenen die in eerste instantie de antwoordkaart niet hebben teruggestuurd.

Bij een derde en vierde groep IVBO'ers wordt voorgesteld een uitgebreide schriftelijke vragenlijst te gebruiken. De ene groep zal een vragenformulier worden voorgelegd, waarbij de meningsvragen over de aansluiting tussen opleiding en voornaamste bezigheid wel zijn opgenomen, terwijl voor de andere groep een versie wordt 
ontwikkeld waarbij deze responsgevoelige vragen niet staan vermeld. Op deze wijze kan worden achterhaald in hoeverre de (algemene) respons wordt verhoogd, indien deze meningsvragen achterwege worden gelaten. Afhankelijk van het resultaat van het proefonderzoek kan dan worden besloten om deze vragen in het vervolg niet, niet ieder jaar, of op andere wijze in de vragenlijst te verwerken.

Ook bij andere vragen zal, in nauwe samenspraak met de deelnemende scholen, worden nagegaan in hoeverre de vragen in vergelijking met de RUBS-vragenlijst moeten worden gewijzigd om de vragen geschikt te maken voor de IVBO'ers. Een randvoorwaarde hierbij is wel dat deze aanpassingen de vergelijkbaarheid tussen de RUBS-enquête en het IVBO-onderzoek niet mogen frustreren. Het overleg met de decanen en de respons- en invulanalyse heeft overigens al een eerste inzicht gegeven op welke wijze de RUBS-vragenlijst voor deze schoolverlaters moet worden aangepast.

Voor een goede praktijkevaluatie van de ingezette instrumenten is een uitgebreid onderzoek onder de non-respondenten van belang. Middels een telefonisch nonresponsonderzoek kan worden achterhaald waarom de schoolverlaters niet hebben deelgenomen aan het onderzoek. De vraag is dan uiteraard of de schoolverlaters die het verkorte vragenformulier voorgelegd hebben gekregen naar verhouding vaak andere redenen opgeven voor het niet willen of kunnen deelnemen dan de schoolverlaters die met een telefonische enquête of een uitgebreide schriftelijke vragenlijst zijn benaderd. Daarnaast kan het non-responsonderzoek worden benut om te toetsen in hoeverre de respons selectief is geweest. In dat geval zal daarmee rekening worden gehouden bij het analyseren en presenteren van de resultaten.

Voorgesteld wordt de scholen die hebben deelgenomen aan de eerste fase van het proefonderzoek, uit te nodigen om ook deel te nemen aan het feitelijke proefonderzoek zelf. De betreffende decanen hebben reeds aangegeven dat zij hieraan in principe graag deelnemen. De betreffende scholen zijn allen in Limburg gevestigd. Daarnaast zou het aan te bevelen zijn wanneer ook een Agrarisch Opleidingscentrum $(A O C)$ wordt gevraagd in het proefonderzoek te participeren. Hierover is reeds kortstondig contact geweest met een AOC in Limburg.

Voor het IVBO bestaat het proefonderzoek aldus uit de volgende projectonderdelen. Instrumentontwikkeling:

- opstellen van handleiding proefonderzoek voor deelnemende scholen;

- opstellen van informatieschema studentenadministratie t.b.v. achtergrondvariabelen;

- opstellen uitgebreid vragenformulier (versie inclusief meningsvragen over aansluiting tussen opleiding en beroep/vervolgopleiding en versie exclusief deze vragen); 
- opstellen verkorte vragenlijst (versie voor schriftelijke bevraging en versie voor telefonische enquête);

- opstellen vragenformulier telefonische non-responsonderzoek.

Dataverzameling en -verwerking:

- opstellen geautomatiseerde data-invoer en -verwerkingsprogramma's;

- leveren van achtergrondgegevens door studentenadministraties;

- uitvoeren en verwerken van schriftelijk en telefonisch onderzoek;

- uitvoeren en verwerken van non-responsonderzoek.

Analyse, evaluatie en rapportage:

- evaluatie instrumentarium;

- analyse onderzoeksresultaten;

- rapportage evaluatie en onderzoeksresultaten.

\subsection{VSO}

Uit de gesprekken zijn twee regio's naar voren gekomen waarin een eventueel te houden pilot-project zou kunnen plaatsvinden: de provincies Limburg en NoordBrabant. In Limburg zou een instrument voor het IBO kunnen worden getest. Een pilot-project voor het VSO zou kunnen aansluiten bij bestaande provinciale projecten in respectievelijk Limburg en Noord-Brabant.

Vanaf 1987 wordt in Noord-Brabant jaarlijks de eerste bestemming van MLKschoolverlaters geregistreerd. Dit gebeurt door de scholen zelf met behulp van een standaard-registratieformulier, dat is ontwikkeld door het Provinciaal Steunpunt Werkgelegenheid (PSW) in Den Bosch. De coördinatie van deze jaarlijkse registratie berust bij het PSW. Daarnaast heeft eenmalig een meting van de latere bestemming van oud-leerlingen van zes Noord-Brabantse MLK-scholen plaatsgevonden. Het moment waarop de latere bestemming werd gemeten, varieerde van een tot drie jaar na het verlaten van de school. De respons bedroeg circa $60 \%$, hetgeen neerkomt op circa 400 schoolverlaters. Vanwege de selectie in de respons, benadrukt het PSW dat in een monitoringsysteem van de latere bestemming veel aandacht moet worden besteed aan het non-responsonderzoek. Het PSW overweegt om eenzelfde meting van de latere bestemming te herhalen, maar dan bij recentere jaargangen schoolverlaters. Een eventueel te houden pilot-project zou niet alleen passen binnen de voornemens van het PSW, maar zou ook gebruik kunnen maken van de door het PSW opgebouwde contacten met de Noordbrabantse VSO-scholen. Het laatste is erg aantrekkelijk gezien de centrale rol van de scholen als verstrekkers van informatie over de bestemming direct na het verlaten van de school.

In Limburg volgen circa 2200 jongeren het VSO. Dit komt neer op 2,9\% van het totaal aantal leerlingen in het Limburgse voortgezet onderwijs. De deelname aan het VSO is sinds 1981 ongeveer verdubbeld. In Limburg, met name in de verstedelijkte gebieden Maastricht, Heerlen en Roermond ligt de deelname aan bepaalde vormen 
van speciaal onderwijs (MLK en ZMOK) verhoudingsgewijs hoger dan het landelijk gemiddelde. De uitstroom van leerlingen uit het VSO naar de reguliere arbeidsmarkt, met name naar het bedrijfsleven, is relatief laag. Van de VSO-/MLK-schoolverlaters in Limburg komt gemiddeld slechts één op de vijf terecht in het bedrijfsleven. Om de doorstroom van deze categorie schoolverlaters naar de reguliere arbeidsmarkt in de toekomst op structurele wijze te vergroten, is in 1992 het pilot-project 'Afstemming VSO-arbeidsmarkt in Limburg' gestart. Dit project wordt gecoördineerd door het RDC-Limburg (Kockelkorn, 1993). Een eventueel te houden pilot-project zou gebruik kunnen maken van de door het RDC-Limburg opgebouwde contacten met de Limburgse VSO-scholen.

Met betrekking tot het VSO zou een pilot-onderzoek zich, evenals bij het IVBO, kunnen beperken tot enkele scholen, in dit geval tot enkele VSO-MLK/LOM-scholen in Noord Brabant, Limburg of in beide genoemde provincies. In het pilot-project zouden de twee instrumenten voor het meten van de bestemming van VSO-schoolverlaters kunnen worden getest, namelijk een standaardformulier voor de VSOscholen (waarmee een aantal persoonskenmerken, opleidingsgegevens en de eerste bestemming worden gemeten) en een beknopte schriftelijke of telefonische enquête onder de ouders/verzorgers (voor het meten van de bestemming na twee jaar). Om na te gaan op welke wijze de bestemming na twee jaar in de praktijk het beste kan worden gemeten, wordt voorgesteld om bij een tweehonderdtal ouders/verzorgers de latere bestemming via een telefonische enquête te meten, en bij eveneens een tweehonderdtal ouders/verzorgers via een schriftelijke enquête. Deze telefonische en schriftelijke proefenquêtes zouden van te voren schriftelijk moeten worden aangekondigd door de desbetreffende scholen.

Het proefonderzoek met betrekking tot het VSO bestaat derhalve uit de volgende projectonderdelen.

Instrumentontwikkeling:

- opstellen van handleiding proefonderzoek voor deelnemende scholen;

- opstellen van standaard vragenformulier voor meten bij VSO-school van persoonsgegevens, opleidingsgegevens en eerste bestemming;

- opstellen vragenformulier voor meten bij ouders/verzorgers van latere bestemming VSO'er (versie schriftelijke en versie telefonisch);

- opstellen vragenformulier telefonisch non-responsonderzoek.

Dataverzameling en -verwerking:

- opstellen geautomatiseerde data-invoer en -verwerkingsprogramma's;

- leveren van achtergrondgegevens door VSO-scholen;

- uitvoeren en verwerken van schriftelijk en telefonisch onderzoek;

- uitvoeren en verwerken van non-responsonderzoek.

Analyse, evaluatie en rapportage:

- evaluatie instrumentarium;

- analyse onderzoeksresultaten; 
- rapportage evaluatie en onderzoeksresultaten.

In hoofdstuk 5 wordt de bovenstaande opzet voor het uitvoeren van het proefonderzoek onder IVBO-scholen en hun schoolverlaters verder uitgewerkt. 


\section{Deel 2}

Proefmeting bestemming schoolverlaters IVBO 


\section{Opzet van de proefmeting}

Tijdens het in deel 1 beschreven vooronderzoek heeft het ROA verkennende gesprekken gevoerd met decanen van drie Limburgse scholen met IVBO-leerlingen over de mogelijkheden en randvoorwaarden voor het registreren van de bestemming van IVBO-schoolverlaters. Mede op basis van deze gesprekken heeft de Directie VO/A van het Ministerie van OCW aan het ROA opdracht verleend om in een proefonderzoek na te gaan welk instrument het meest geschikt is om de bestemming van IVBO-schoolverlaters te registreren. In concreto heeft de Directie VO/A van OCW opdracht gegeven om twee instrumenten te testen onder gediplomeerde én ongediplomeerde IVBO-schoolverlaters, namelijk een kort schriftelijk vragenformulier en een telefonische enquête. Teneinde deze schriftelijke en telefonische enquêtes zo beknopt mogelijk te maken, is een schoolformulier opgesteld aan de hand waarvan de schooladministratie of de decaan vóóraf de benodigde achtergrondgegevens over de IVBO'ers kan noteren (zie bijlage 6).

Reeds tijdens het vooronderzoek is in overleg met de schooldekanen geïnventariseerd welke onderwerpen in zowel de vragenlijst als het schoolformulier aan bod zouden dienen te komen. Alvorens de feitelijke proefmetingen uit te voeren, is in nauwe samenspraak met de deelnemende scholen nagegaan in hoeverre de vragen van de RUBS-vragenlijst moesten worden gewijzigd om deze geschikt te maken voor IVBO'ers. Een randvoorwaarde hierbij is geweest dat deze aanpassingen de vergelijkbaarheid tussen de RUBS-enquête en het IVBO-onderzoek zo weinig mogelijk aantasten.

Aangezien het proefonderzoek als doel heeft om na te gaan welke dataverzamelingsmethode in de praktijk het beste functioneert, heeft bij een deel van de schoolverlaters de proefmeting via een telefonische enquête plaatsgevonden, terwijl een ander deel van de schoolverlaters met een korte schriftelijke vragenlijst is benaderd. De schoolverlaters waarbij de enquete telefonisch is afgenomen, zijn deels door het ROA benaderd. Bij een ander deel van de schoolverlaters waarbij de enquête telefonisch is afgenomen, zijn de IVBO-docenten ingeschakeld.

Het IVBO-proefonderzoek heeft de volgende projectonderdelen omvat: Instrumentontwikkeling

- opstellen handleiding proefonderzoek voor deelnemende scholen;

- opstellen schoolformulier t.b.v. de registratie van achtergrondvariabelen;

- opstellen verkorte vragenlijst (versie voor schriftelijke bevraging en versie voor telefonische enquête).

Dataverzameling en -verwerking

- opstellen data-invoer en -verwerkingsprogramma;

- leveren van achtergrondgegevens door schooladministraties;

- uitvoeren en verwerken schriftelijk en telefonisch onderzoek. 
Analyse, evaluatie en rapportage

- evaluatie instrumentarium;

- analyse onderzoeksresultaten;

- rapportage evaluatie en onderzoeksresultaten.

Eind 1994 zijn zes scholen bezocht teneinde het doel, de inhoud en de opzet van het proefonderzoek toe te lichten en de school te vragen om aan het proefonderzoek mee te werken. Nadat was toegelicht welke onderwerpen in de vragenlijsten aan bod zouden komen, zag één school af van medewerking aangezien zij reeds participeerde in het Schoolverlaters Volgsysteem van de Landelijke Vereniging van Schooldekanen. In 1995 is overigens een pilotproject gestart om het RUBS-onderzoek en het Schoolverlaters Volgsysteem in één systematiek te integreren. Dit heeft ertoe geleid dat nu een gecombineerd aanbod aan de scholen wordt gedaan. Ook twee andere scholen hebben uiteindelijk afgezien van medewerking zodat drie scholen resteerden voor de proefmeting.

In de periode februari-mei 1995 zijn de bovengenoemde twee instrumenten uiteindelijk getest bij alle IVBO-schoolverlaters (zowel gediplomeerde als ongediplomeerde van schooljaar 1993/94) van deze drie scholen.

Bij iedere school is $1 / 3$ van de IVBO-schoolverlaters benaderd middels een schriftelijke vragenlijst en $2 / 3$ van de schoolverlaters middels een telefonische enquête. Van de schoolverlaters waarbij de enquête telefonisch is afgenomen, is de helft door het ROA benaderd en de andere helft door de IVBO-dekanen. Door middel van een aselecte steekproeftrekking uit de schooladministraties is bepaald welke schoolverlaters telefonisch door de school, telefonisch door het ROA of schriftelijk door het ROA zijn benaderd.

Bij de drie deelnemende scholen ging het in totaal om 106 IVBO-schoolverlaters ${ }^{10}$. Hiervan zijn er 35 schriftelijk benaderd, 36 telefonisch door de eigen school en 35 telefonisch door het ROA.

10. Welke IVBO'ers in het proefonderzoek vallen, staat gedefinieerd in de bijlage: Definitie van de term 'schoolverlater'. 


\section{Representativiteit en betrouwbaarheid van de on- derzoekinstrumenten}

Bij het proefonderzoek gaat het niet zo zeer om de beantwoording van de vraag waar de IVBO-schoolverlaters terecht komen, maar primair om de vraag op welke wijze hun bestemming het beste kan worden gemeten: telefonisch (door de school of een onderzoekinstituut) danwel schriftelijk door een onderzoekinstituut. Voor dit doel zijn twee formulieren ontworpen:

- een Schoolformulier proefonderzoek bestemming IVBO'ers (zie bijlage 6), in te vullen door de school;

- een Vragenlijst schoolverlaters IVBO, die bij de schriftelijke enquête (zie bijlage 7) wordt ingevuld door de schoolverlaters zelf, en bij de telefonische enquêtes (zie bijlage 8 ) door de dekanen of het ROA (aan de hand van de antwoorden die door de schoolverlater tijdens het telefoongesprek worden verstrekt)

\subsection{Dataverzameling en respons}

De schriftelijke enquête door het ROA bestond uit twee mailingen. De eerste mailing, gericht aan de 35 schoolverlaters van de schriftelijke proefmeting resulteerde in de terugontvangst van 14 ingevulde vragenlijsten en 6 onbestelbaar (adres onbekend) geretourneerde vragenlijsten. Drie weken later werden de 15 schoolverlaters die tot dan nog niet hadden gerespondeerd (en van wie geen onbestelbaar geretourneerde vragenlijsten waren ontvangen) door het ROA gebeld met het verzoek alsnog hun medewerking aan het onderzoek te verlenen. Indien nodig werd een nieuwe vragenlijst toegestuurd. Dit telefonisch en schriftelijk rappe] resulteerde in de terugontvangst van drie ingevulde vragenlijsten. Daarmee bedroeg de uiteindelijke respons bij de schriftelijke enquête $49 \%$ :

- respons 1e mailing

- respons telefonisch en schriftelijk rappel

- non-respons vanwege adres onbekend

- overige non-respons

Door de bank genomen, leiden telefonische enquêtes door de scholen tot een hogere respons dan de telefonische benadering door een onderzoeksinstituut (tabel 6.1). Hierbij dient evenwel te worden vermeld dat de respons bij de telefonische benadering door de scholen sterk naar school varieert. De respons bedroeg bij de drie deelnemende scholen respectievelijk $29 \%, 43 \%$ en $75 \%$. Opvallend is dat de schriftelijke benadering door een voor de schoolverlaters onbekend instituut tot een bijna even hoge respons leidt als telefonische benadering door de 'eigen' school. De telefonische enquêtrice van het ROA heeft getracht om de schoolverlaters of ouders/verzorgers die overdag niet konden worden bereikt in de avonduren alsnog telefonisch te bereiken. Aan de dekanen is gevraagd om hetzelfde te doen. 
Tabel 6.1

Respons

\begin{tabular}{lccc}
\hline Wijze van bevraging & Benaderd & $\begin{array}{l}\text { Gerespon- } \\
\text { deerd }\end{array}$ & Respons \\
\hline Telefonisch door school & 36 & 19 & $53 \%$ \\
Telefonisch door onderzoekinstituut & 35 & 14 & $40 \%$ \\
Schriftelijk door onderzoekinstituut & 35 & 17 & $49 \%$ \\
Totaal & 106 & 50 & $47 \%$ \\
\hline
\end{tabular}

Tabel 6.2 laat zien dat telefonisch enquêteren in de helft van de gevallen vanwege onbereikbaarheid leidt tot non-respons. De meeste telefonische non-respons is het gevolg van onbereikbaarheid na herhaald bellen, gevolgd door onbereikbaarheid vanwege een foutief geregistreerd of inmiddels achterhaald telefoonnummer uit de schooladministratie. Non-respons ten gevolge van geheime telefoonnummers of het niet bezitten van telefoon komt veel minder vaak voor, evenals weigering om aan het onderzoek mee te werken. Dit zal wellicht in de Randstad vaker het geval zijn.

Tabel 6.2

Resultaat telefonische benadering

\begin{tabular}{lccc}
\hline & Door school & Door ROA & Totaal \\
\hline Respons & $53 \%$ & $40 \%$ & $46 \%$ \\
& & & \\
Non-respons, want: & $3 \%$ & $3 \%$ & $3 \%$ \\
- geen telefoon/geheim telefoonnummer & $3 \%$ & $3 \%$ & $3 \%$ \\
- telefoon afgesloten & $11 \%$ & $11 \%$ & $11 \%$ \\
- telefoonnummer klopte niet & $28 \%$ & $31 \%$ & $30 \%$ \\
- na tenminste 5 keer bellen onbereikbaar & $0 \%$ & $3 \%$ & $1 \%$ \\
- weigert medewerking & $3 \%$ & $9 \%$ & $6 \%$ \\
- andere reden & 36 & 35 & 71 \\
Totaal n (= 100\%) & & & \\
\hline
\end{tabular}

De overgrote meerderheid (85\%) van de telefonische interviews is gevoerd met de schoolverlaters zelf; in $15 \%$ van de telefonische interviews is gesproken met de ouders of verzorgers van de schoolverlaters.

\subsection{Representativiteit}

Bij het proefonderzoek gaat het primair om de vraag op welke wijze de bestemming van schoolverlaters van het IVBO het beste kan worden gemeten: telefonisch (door de school of een onderzoekinstituut) dan wel schriftelijk (door een onderzoekinstituut). Bij een telefonische enquête kan non-respons optreden omdat schoolverlaters geen telefoon of een geheim telefoonnummer hebben. Zelfs bij een relatief 
groot aandeel van schoolverlaters zonder telefoon of met een geheim telefoonnummer, hoeft dit voor de representativiteit geen nadelige consequenties te hebben zo lang de niet-telefonisch te bereiken schoolverlaters maar niet systematisch afwijken van de schoolverlaters die in beginsel wel telefonisch te bereiken zijn.

Tabel 6.3

Vergelijking telefonisch te bereiken schoolverlaters en niet-telefonisch te bereiken schoolverlaters, op basis van de gegevens zoals door de scholen zijn verstrekt op het schoolformulier

\begin{tabular}{|c|c|c|c|}
\hline & $\begin{array}{l}\text { Telefonisch } \\
\text { te bereiken }\end{array}$ & $\begin{array}{l}\text { Niet-telefonisch } \\
\text { te bereiken }\end{array}$ & Totale populatie \\
\hline $\begin{array}{l}\text { Geslacht: } \\
\text { - \% man } \\
\text { - \% vrouw }\end{array}$ & $\begin{array}{l}26 \% \\
74 \%\end{array}$ & $\begin{array}{r}0 \% \\
100 \%\end{array}$ & $\begin{array}{l}24 \% \\
76 \%\end{array}$ \\
\hline $\begin{array}{l}\text { Nationaliteit: } \\
\text { - Nederlandse } \\
\text { - andere }\end{array}$ & $\begin{array}{l}80 \% \\
20 \%\end{array}$ & $\begin{array}{l}88 \% \\
12 \%\end{array}$ & $\begin{array}{l}80 \% \\
20 \%\end{array}$ \\
\hline $\begin{array}{l}\text { Sector IVBO-opleiding: } \\
\text { - verzorgend } \\
\text { - agrarisch }\end{array}$ & $\begin{array}{l}71 \% \\
29 \%\end{array}$ & $\begin{array}{r}100 \% \\
0 \%\end{array}$ & $\begin{array}{l}73 \% \\
27 \%\end{array}$ \\
\hline $\begin{array}{l}\text { IVBO-diploma behaald: } \\
\text { - ja } \\
\text { - nee }\end{array}$ & $\begin{array}{l}73 \% \\
27 \%\end{array}$ & $\begin{array}{l}63 \% \\
38 \%\end{array}$ & $\begin{array}{l}72 \% \\
28 \%\end{array}$ \\
\hline
\end{tabular}

Van de 106 in het proefonderzoek betrokken schoolverlaters zijn er 8 (8\%) niet telefonisch te bereiken omdat zij geen telefoon hebben of een geheim telefoonnummer hebben. De deelpopulatie van niet telefonisch te bereiken IVBO-schoolverlaters is dus beperkt van omvang en weegt derhalve, zelfs bij een systematische afwijking, slechts in geringe mate door in de representativiteit. In hoeverre een in andere regio's eventueel hoger procentueel aandeel van niet telefonisch te bereiken IVBOschoolverlaters echter een telefonische benadering in de weg staat, kan pas worden beantwoord nadat beide groepen schoolverlaters met elkaar zijn vergeleken. In tabel 6.3 wordt derhalve een aantal achtergrondkenmerken van de telefonisch te bereiken schoolverlaters en de niet-telefonisch te bereiken schoolverlaters vergeleken. Tabel 6.3 laat zien dat de niet telefonisch te bereiken schoolverlaters nauwelijks afwijken van de schoolverlaters die in beginsel wel telefonisch kunnen worden bereikt. Uit het oogpunt van de omvang van de selectiviteit van de niet telefonisch te bereiken schoolverlaters staat niets een telefonische benadering in de weg.

Een tweede aspect van representativiteit betreft de vraag in hoeverre de respondenten (of de non-respondenten) een afwijkende groep vormen ten opzichte van de totale populatie. Om deze vraag te kunnen beantwoorden worden in tabel 6.4 per benaderingswijze de desbetreffende populatiegegevens en steekproefgegevens op een aantal kenmerken vergeleken. Hierbij dient te worden opgemerkt dat 'een representatieve steekproef in feite niet bestaat. Immers op afzonderlijke deelkenmer- 
Tabel 6.4

Vergelijking totale populatie en respons, op basis van de gegevens zoals door de scholen zijn verstrekt op het schoolformulier

\begin{tabular}{|c|c|c|c|c|}
\hline & $\begin{array}{l}\text { Populatie } \\
\text { telef. school }\end{array}$ & $\begin{array}{l}\text { Steekproef } \\
\text { telef. school }\end{array}$ & $\begin{array}{l}\text { Populatie } \\
\text { telef. ROA }\end{array}$ & $\begin{array}{l}\text { Steekproef } \\
\text { telef. ROA }\end{array}$ \\
\hline $\begin{array}{l}\text { Geslacht: } \\
\text { - \% man } \\
\text { - \% vrouw } \\
\text { Nationaliteit: }\end{array}$ & $\begin{array}{l}19 \% \\
81 \%\end{array}$ & $\begin{array}{r}0 \% \\
100 \%\end{array}$ & $\begin{array}{l}16 \% \\
84 \%\end{array}$ & $\begin{array}{l}14 \% \\
86 \%\end{array}$ \\
\hline $\begin{array}{l}\text { - Nederlandse } \\
\text { - andere } \\
\text { Vooropleiding: }\end{array}$ & $\begin{array}{l}89 \% \\
12 \%\end{array}$ & $\begin{array}{l}86 \% \\
14 \%\end{array}$ & $\begin{array}{l}72 \% \\
28 \%\end{array}$ & $\begin{array}{l}57 \% \\
43 \%\end{array}$ \\
\hline $\begin{array}{l}\text { - basisschool } \\
\text { - LOM } \\
\text { - VSO-LOM } \\
\text { - VSO-MLK } \\
\text { - (I)VBO } \\
\text { - buitenlandse } \\
\text { - andere }\end{array}$ & $\begin{array}{r}52 \% \\
0 \% \\
4 \% \\
12 \% \\
4 \% \\
0 \% \\
28 \%\end{array}$ & $\begin{array}{r}58 \% \\
0 \% \\
0 \% \\
16 \% \\
0 \% \\
0 \% \\
26 \% \\
\end{array}$ & $\begin{array}{r}48 \% \\
8 \% \\
4 \% \\
0 \% \\
0 \% \\
8 \% \\
32 \%\end{array}$ & $\begin{array}{r}57 \% \\
0 \% \\
0 \% \\
0 \% \\
0 \% \\
0 \% \\
43 \%\end{array}$ \\
\hline $\begin{array}{l}\text { Diploma vooropleiding: } \\
\text { - nee } \\
\text { - niet van toepassing } \\
\text { Sector IVBO-opleiding: }\end{array}$ & $\begin{array}{l}13 \% \\
88 \%\end{array}$ & $\begin{array}{r}0 \% \\
100 \%\end{array}$ & $\begin{array}{r}8 \% \\
92 \%\end{array}$ & $\begin{array}{l}14 \% \\
86 \%\end{array}$ \\
\hline $\begin{array}{l}\text { - verzorgend } \\
\text { - agrarisch }\end{array}$ & $\begin{array}{l}72 \% \\
28 \%\end{array}$ & $\begin{array}{l}84 \% \\
16 \%\end{array}$ & $\begin{array}{l}71 \% \\
29 \%\end{array}$ & $\begin{array}{l}86 \% \\
14 \%\end{array}$ \\
\hline \multirow[t]{2}{*}{$\begin{array}{l}\text { IVBO-diploma behaald: } \\
\text { - ja } \\
\text { - nee }\end{array}$} & $\begin{array}{l}62 \% \\
39 \%\end{array}$ & $\begin{array}{l}79 \% \\
21 \%\end{array}$ & $\begin{array}{l}80 \% \\
20 \%\end{array}$ & $\begin{array}{l}71 \% \\
29 \%\end{array}$ \\
\hline & $\begin{array}{l}\text { Populatie } \\
\text { schriftelijk }\end{array}$ & $\begin{array}{l}\text { Steekproef } \\
\text { schriftelijk }\end{array}$ & & \\
\hline $\begin{array}{l}\text { Geslacht: } \\
\text { - \% man } \\
\text { - \% vrouw }\end{array}$ & $\begin{array}{l}36 \% \\
64 \%\end{array}$ & $\begin{array}{l}41 \% \\
59 \%\end{array}$ & & \\
\hline $\begin{array}{l}\text { Nationaliteit: } \\
\text { - Nederlandse } \\
\text { - andere }\end{array}$ & $\begin{array}{l}80 \% \\
20 \%\end{array}$ & $\begin{array}{l}76 \% \\
24 \%\end{array}$ & & \\
\hline $\begin{array}{l}\text { Vooropleiding: } \\
\text { - basisschool } \\
\text { - LOM } \\
\text { - VSO-LOM } \\
\text { - VSO-MLK } \\
\text { - (I)VBO } \\
\text { - buitenlandse } \\
\text { - andere }\end{array}$ & $\begin{array}{r}44 \% \\
4 \% \\
0 \% \\
16 \% \\
4 \% \\
8 \% \\
24 \%\end{array}$ & $\begin{array}{r}35 \% \\
0 \% \\
0 \% \\
24 \% \\
0 \% \\
18 \% \\
24 \%\end{array}$ & & \\
\hline $\begin{array}{l}\text { Diploma vooropleiding: } \\
\text { - nee } \\
\text { - niet van toepassing }\end{array}$ & $\begin{array}{r}4 \% \\
96 \%\end{array}$ & $\begin{array}{r}0 \% \\
100 \%\end{array}$ & & \\
\hline $\begin{array}{l}\text { Sector IVBO-opleiding: } \\
\text { - verzorgend } \\
\text { - agrarisch }\end{array}$ & $\begin{array}{l}75 \% \\
25 \%\end{array}$ & $\begin{array}{l}71 \% \\
29 \%\end{array}$ & & \\
\hline $\begin{array}{l}\text { IVBO-diploma behaald: } \\
\text { - ja } \\
\text { - nee }\end{array}$ & $\begin{array}{l}76 \% \\
24 \%\end{array}$ & $\begin{array}{l}82 \% \\
18 \%\end{array}$ & & \\
\hline
\end{tabular}


ken kan een steekproef zeer wel representatief zijn voor de totale populatie, maar het blijft altijd nog maar de vraag of dit ook geldt voor de kombinatie van alle in een onderzoek opgenomen kenmerken (nog afgezien van niet in een onderzoek opgenomen kenmerken die wellicht van belang zijn voor de beantwoording van de vragen in een onderzoek).

In tabel 6.4 komt naar voren dat mannelijke respondenten bij een telefonische benadering door de scholen zijn ondervertegenwoordigd. Dit zal samenhangen met de bevinding dat de mannelijke respondenten vier keer zo vaak een betaalde baan blijken te hebben ( $67 \%$ betaald werk) dan de vrouwelijke respondenten $(15 \%$ betaald werk) en derhalve veel vaker na herhaald bellen, tenminste als dit niet ook in de avonduren gebeurt, telefonisch niet kunnen worden bereikt. Non-respons in de telefonische benadering door scholen als gevolg van onbereikbaarheid is bij $80 \%$ van de mannelijke non-respondenten en $43 \%$ van de vrouwelijke non-respondenten in de telefonische enquête door de scholen het geval geweest. De lichte ondervertegenwoordiging van de agrarische opleidingssector in de telefonische enquête door de scholen is een rechtstreeks gevolg van de ondervertegenwoordiging van mannen, aangezien mannen vaker agrarische opleidingen (56\%) hebben gevolgd dan vrouwen (18\%). Verder blijkt dat ongediplomeerde schoolverlaters ondervertegenwoordigd zijn in de respons bij een telefonische bevraging door scholen. Bij de respons op de telefonische enquête door het ROA blijken allochtonen oververtegenwoordigd te zijn evenals schoolverlaters die een verzorgende opleiding hebben gevolgd. Bij een schriftelijke enquête zijn de verschillen tussen populatiekenmerken en kenmerken van de respondenten door de bank genomen het kleinst.

\subsection{Betrouwbaarheid van het meetinstrument}

Aan de scholen is op het schoolformulier de volgende vraag voorgelegd: 'Wat doet de leerling op dit moment?'. De school kon hierbij kiezen uit één van de volgende antwoordcategorieën:

- werkloos;

- werk;

- dagopleiding;

- leerlingwezen;

- militaire dienst;

- huishouden;

- anders, namelijk:

- onbekend.

In zowel de telefonische enquête als de schriftelijke enquête is de bezigheid van de schoolverlater op advies van de dekanen met behulp van de volgende deelvragen gemeten:

- Heb je op dit moment betaald werk?

- Zo nee, zou je een baan van minstens 12 uur per week willen hebben? 
- Ben je op dit moment scholier?

- Zit je in het leerlingwezen? (bijv. VOLTT, SOM, SVK, OVD)

- Zit je op dit moment in militaire dienst?

Een onderzoek met uitsluitend schoolformulieren impliceert dat slechts bij eenderde van de schoolverlaters (36\%) de bestemming na circa anderhalf jaar kan worden vastgesteld. Vooral vanwege de non-respons brengt een telefonische of schriftelijke enquête hierin slechts geringe verbetering. Met een telefonische enquête kan uiteindelijk bij $44 \%$ van de schoolverlaters de huidige bestemming worden achterhaald en met een schriftelijke enquête bij $49 \%$ van de schoolverlaters (tabel 6.5 ).

\section{Tabel 6.5}

Omvang waarin de huidige bestemming van schoolverlaters kan worden gemetenmet behulp van het schoolformulier en de enquêtes

\begin{tabular}{|c|c|c|c|c|c|}
\hline & \multirow[t]{2}{*}{ Schoolformulier } & \multicolumn{3}{|c|}{ Telefonische enquête door } & \multirow{2}{*}{$\begin{array}{l}\text { Schriftelijke } \\
\text { enquête }\end{array}$} \\
\hline & & school & ROA & totaal & \\
\hline $\begin{array}{l}\text { Bestemming niet beke } \\
\text { - non-respons } \\
\text { - niet ingevuld } \\
\text { - 'onbekend' ingevuld }\end{array}$ & nd: $\begin{array}{r}\text { * } \\
30 \% \\
34 \%\end{array}$ & $\begin{array}{r}47 \% \\
3 \%\end{array}$ & $\begin{array}{r}60 \% \\
0 \%\end{array}$ & $\begin{array}{r}54 \% \\
2 \%\end{array}$ & $\begin{array}{r}51 \% \\
0 \%\end{array}$ \\
\hline Bestemming bekend & $36 \%$ & $50 \%$ & $40 \%$ & $44 \%$ & $49 \%$ \\
\hline
\end{tabular}

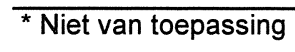

De huidige bestemming, gemeten in de enquête, is als extern criterium gebruikt om na te gaan hoe betrouwbaar de huidige bestemming met behulp van de schoolformulieren kan worden gemeten. Gebleken is dat bij $83 \%$ van de cases de huidige bestemming volgens het schoolformulier en de huidige bestemming gemeten in de enquêtes met elkaar overeenkomen. Gelet op het beperkte aantal relevante antwoordcategorieën (213 van alle respondenten gaat naar vervolgonderwijs) is deze overeenkomst vrij laag. Immers, de betrouwbaarheid van het schoolformulier zal met name laag zijn voor de categorie schoolverlaters die uitgestroomd zijn naar de arbeidsmarkt. We concluderen derhalve dat het schoolformulier geen goed alternatief biedt voor de beide andere meetinstrumenten.

\subsection{Betrouwbaarheid en vraagstelling}

Het doorgaans gering ontwikkelde abstractieniveau van IVBO'ers kan ertoe leiden dat zij bepaalde vragen niet goed begrijpen, waardoor de vragen niet of in onvoldoende mate datgene meten wat zij beogen te meten. Om dit probleem zo veel mogelijk te ondervangen is eerst een verkorte en vereenvoudigde versie van de RUBS-vragenlijst voor commentaar aan de dekanen van de zes benaderde scholen voorgelegd en vervolgens bijgesteld. Daarna is de bijgestelde versie van de vragen- 
lijst opnieuw voor commentaar voorgelegd aan de dekanen van de drie scholen die aan het proefonderzoek hebben meegewerkt. Om na te gaan welke vragen voor IVBO-schoolverlaters eventueel problematisch zijn geweest om in te vullen, is bovendien zowel aan de telefonische vragenlijst als aan de schriftelijke vragenlijst een aantal evaluatievragen toegevoegd.

\section{Commentaar dekanen op verkorte RUBS-vragenlijst}

De dekanen adviseerden om:

1 de omvang van de vragenlijst zo beperkt mogelijk te houden;

2 geen uitvoerige toelichtingen bij de vragen opnemen;

3 bij gesloten vragen slechts een beperkt aantal antwoordcategorieën op te nemen (beter om aparte deelvragen op te nemen);

4 geen routing in de vragenlijst toe te passen, dus geen doorverwijzingen naar andere vragen op te nemen;

5 het taalgebruik zo eenvoudig mogelijk te houden;

6 niet, zoals bij de RUBS-vragenlijst links de vraag op te nemen en rechts de bijbehorende antwoordcategorieën.

Het eerste en vooral tweede advies heeft vergaande consequenties voor de mate waarin met name de begrippen beroepsbevolking en werkloosheid conform CBSdefinities kunnen worden gemeten en daarmee voor de vergelijkbaarheid met de resultaten van bijvoorbeeld de RUBS-enquête. Het derde en vierde advies komt de consistentie bij de beantwoording van de vragen niet ten goede en legt een extra zware claim op de data-controle en -cleaning. Hierop zal in paragraaf 6.6 nader worden ingegaan

\section{Evaluatievragen telefonische vragenlijst}

Aan degene die de telefonische enquête afnam, is gevraagd om na elk telefoongesprek de volgende drie vragen te beantwoorden:

1 Hoe lang duurde het gesprek?

2 Met welke vragen had de respondent moeite?

3 Hoe verliep het gesprek?

De eerste vraag is gesteld om een indicatie te krijgen van het tijdbeslag van het telefonische enquêteren en daarmee van de kosten. De tweede vraag is gesteld om na te gaan welke vragen eventuele bijstelling behoeven, aangezien zij tot systematische problemen bij de beantwoording leidden. De derde vraag is gesteld om een indicatie te krijgen van het eventuele verschil in sfeer en daarmee van potentiële verschillen in respons tussen een telefonische enquête door de 'eigen' vertrouwde school en een telefonische enquête door een onbekend onderzoekinstituut. 
De gesprekken duurden gemiddeld zo'n acht minuten (7,8 minuten). De telefonische enquêtes die door het ROA werden afgenomen duurden door de bank genomen twee minuten langer (gemiddelde duur 9,0 minuten) dan de telefonische interviews door de scholen (gemiddelde duur 7,1 minuten). De gesprekken door de scholen varieerden sterker in lengte (standaardafwijking 4,0 minuten) dan de interviews door het ROA (standaardafwijking 1,7 minuten).

De scholen hebben geen enkele vraag genoemd waarmee zich problemen bij het telefonisch enquêteren hebben voorgedaan. Bij drie telefonische interviews door het ROA deden zich incidenteel problemen voor bij de volgende vragen:

- vraag 3c (1 keer): Zo nee, zou je een baan van minstens 12 uur per week willen hebben?

- vraag 4b (1 keer): Zo ja, welke opleiding volg je nu?

- vraag $5 a$ (1 keer): Zit je in het leerlingwezen?

- vraag 10 (1 keer): Hoe past het werk dat je nu doet bij je vroegere opleiding?

- vraag 12 (1 keer): Stel, je vindt nú een baan. Hoe snel kun je daarmee dan beginnen?

Er was dus geen enkele vraag waarmee zich in de telefonische enquête meermaals problemen hebben voorgedaan.

Zowel bij de school (84\%) als bij het ROA (71\%) zijn de meeste telefonische gesprekken 'erg makkelijk/spontaan' verlopen.

\section{Evaluatievragen schriftelijke vragenlijst}

Aan de schriftelijke vragenlijst zijn de volgende vijf evaluatievragen toegevoegd:

1 Hoe lang heb je er over gedaan om de vragenlijst in te vullen?

2 Waren er moeilijke vragen bij?

3 Zo ja, welke vragen vond je moeilijk?

4 Waarom vond je deze vragen moeilijk?

5 Heb je hulp van anderen nodig gehad om de vragenlijst in te vullen?

Van de 17 respondenten op de schriftelijke enquête hebben er $13(76 \%)$ deze vijf evaluatievragen beantwoord. Gebleken is dat deze 13 respondenten gemiddeld 9,3 minuten nodig hadden om de vragenlijst in te vullen. De zeer grote standaardafwijking van 8,6 minuten wijst echter op aanzienlijke verschillen in benodigde invultijd. Deze varieert dan ook van 2 minuten tot wel 30 minuten. De meerderheid $(77 \%)$ heeft echter 10 minuten of minder nodig gehad. Van de 13 schoolverlaters die de evaluatievragen hebben beantwoord, vond niemand dat er moeilijke vragen bij waren. Dit lijkt echter in tegenspraak te zijn met de bevinding dat één respondent 30 minuten nodig heeft gehad om de vragenlijst in te vullen en dat vier respondenten (31\%) aangaven dat zij hulp van anderen nodig hadden om de vragenlijst in te vullen. Wellicht heeft niemand willen toegeven dat hij of zij bepaalde vragen moeilijk 
vond. De analyse van de respons per vraag in paragraaf 6.5 zal echter de eventuele vragen aan het licht brengen waarmee IVBO-schoolverlaters bij een schriftelijke bevraging moeite hebben.

\subsection{Respons per vraag}

Teneinde de schriftelijke vragenlijst (zie bijlage 7) en de telefonische vragenlijst (zie bijlage 8) zo beknopt mogelijk te maken, is eerst een schoolformulier opgesteld aan de hand waarvan de schooladministratie of de decaan vóóraf de benodigde achtergrondgegevens over de IVBO'ers kan noteren (zie bijlage 6). In deze paragraaf wordt eerst voor het schoolformulier nagegaan hoe volledig de gevraagde gegevens zijn verstrekt. Vervolgens wordt voor de vragenlijst aangegeven hoe hoog de respons per vraag is.

\section{Schoolformulier}

Tabel 6.6 geeft een overzicht van de mate waarin scholen de gevraagde gegevens over de schoolverlaters op het schoolformulier hebben verstrekt. Gebleken is dat persoonsgegevens, gegevens over de vooropleiding en gegevens over de gevolgde IVBO-opleiding niet aan de schoolverlaters zelf hoeven te worden gevraagd, aangezien deze gegevens vrijwel steeds door de scholen kunnen worden verstrekt. Hetzelfde geldt met betrekking tot de eerste bestemming na verlaten van de school. lets minder vaak, maar toch nog altijd in zo'n $70 \%$ van de gevallen, zijn IVBOscholen op de hoogte van het schooltype van degenen die zijn doorgestroomd naar vervolgopleidingen en de bezigheid van de schoolverlaters op het moment van enquêteren. Echter, het beroep en de branche van degenen die zijn gaan werken zijn meestal onbekend bij de school.

\section{Vragenlijsten}

De vragen $1,2 a, 3 a, 4 a, 5 a, 6$ en $11 \mathrm{t} / \mathrm{m} 14$ van de telefonische en schriftelijke vragenlijst moesten door iedereen worden ingevuld. Tabel 6.7 geeft een overzicht van de hoogte van de respons op deze vragen. De resultaten in tabel 6.7 laten zien dat de drie wijzen van bevraging elkaar niet veel ontlopen wat de hoogte van de respons per vraag betreft. De grootste verschillen doen zich voor met betrekking tot drie vragen naar de huidige bezigheden (vraag 3a, 5a en 6) waarbij de scholen slechter scoren en vraag 12 waarbij zowel de telefonische enquête door de school als de schriftelijke enquête slechter scoren. Overigens kan de non-respons bij een telefonisch gestelde vraag het gevolg zijn van het feit dat de respondent de vraag niet kan of wil beantwoorden of resulteren uit een niet-volledige verslaglegging door de enquêteur. De bevinding dat bij de vragen naar de huidige bezigheden (vraag3a, $5 a$ en 6) de telefonische bevraging door de scholen slechter scoort dan de telefonische enquête door het ROA en de schriftelijke enquête, wijst op de laatstgenoemde 
reden voor non-respons (althans bij vraag 3a, 5a en 6). Hierbij dient te worden vermeld dat de enquêtrice van het ROA exact dezelfde instructies heeft ontvangen als de dekanen. De duidelijk hogere score van het ROA bij vraag 12 (Stel, je vindt nú een baan. Hoe snel kun je daarmee dan beginnen?) wijst erop dat deze vraag zonder nadere toelichting niet altijd even duidelijk is geweest. Immers, het beantwoorden van deze vraag ligt minder voor de hand voor schoolverlaters die niet naar werk hebben gezocht. Worden deze schoolverlaters buiten beschouwing gelaten, dan bedraagt de respons op deze vraag bij eik van de drie benaderingswijzen $100 \%$. Samenvattend kan worden gesteld dat een schriftelijke enquête even goed voldoet als een telefonische enquête door een onderzoeksinstituut, tenminste wat de hoogte van de respons per vraag betreft. Een telefonische bevraging door de eigen school voldoet wat dit betreft iets minder, aangezien dekanen de verstrekte antwoorden niet steeds volledig registreren.

Tabel 6.6

Respons op de gevraagde gegevens in het schoolformulier

\begin{tabular}{lr}
\hline Gevraagde gegevens & Respons \\
\hline & \\
\hline Persoonskenmerken: & $100 \%$ \\
- geboortejaar en -maand & $100 \%$ \\
- geslacht & $100 \%$ \\
- nationaliteit & \\
Vooropleiding: & $97 \%$ \\
- schooltype vooropleiding & $96 \%$ \\
- wel/niet diploma behaald & \\
Gevolgde IVBO-opleiding: & $96 \%$ \\
- gevolgde opleidingsrichting & $99 \%$ \\
- jaar en maand begin opleiding & $100 \%$ \\
- klas begin opleiding & $100 \%$ \\
- jaar en maand einde opleiding & $99 \%$ \\
- klas einde opleiding & $100 \%$ \\
- wel/niet diploma behaald & $92 \%$ \\
- aantal en niveau gevolgde vakken & \\
Bestemming na de IVBO-opleiding: & \\
- bezigheid na verlaten opleiding & $90 \%$ \\
- schooltype vervolgopleiding & $71 \%$ \\
- branche werkenden & $37 \%$ \\
- beroep werkenden & $12 \%$ \\
- bezigheid op enquêtemoment & $70 \%$ \\
\hline * Indien van toepassing & \\
\hline
\end{tabular}

De vragen $2 b, 3 b, 3 c, 4 b, 4 c, 5 b$ en 7 t/m 10 van de telefonische en schriftelijke vragenlijst hoefden niet door iedereen te worden beantwoord. Deze vragen kunnen terecht zijn ingevuld, terecht zijn overgeslagen (niet van toepassing), ten onrechte zijn ingevuld of ten onrechte zijn overgeslagen. Ten onrechte ingevulde vragen vormen geen probleem aangezien zij bij de datacleaning kunnen worden gehercodeerd als 'niet van toepassing'. Ten onrechte overgeslagen vragen vormen wel een 
probleem aangezien het antwoord dan onbekend is (= non-respons). Tabel 6.8 geeft een overzicht van de hoogte van de non-respons bij deze vragen. De teller wordt gevormd door het aantal keren dat de desbetreffende vraag ten onrechte niet is ingevuld; de noemer door het aantal keren dat de desbetreffende vraag had moeten worden ingevuld.

Tabel 6.7

Respons op de vragen in de vragenlijst

\begin{tabular}{lrrrr}
\hline & \multicolumn{2}{c}{$\begin{array}{l}\text { Repons in telefonisch enquête } \\
\text { school }\end{array}$} & ROA & Respons in schriftelijke enquête \\
& & & & \\
& & & \\
\hline & & & \\
totaal & & \\
Vraag 1 & $100 \%$ & $100 \%$ & $100 \%$ & $94 \%$ \\
Vraag 2a & $95 \%$ & $100 \%$ & $94 \%$ & $94 \%$ \\
Vraag 4a & $79 \%$ & $100 \%$ & $85 \%$ & $94 \%$ \\
Vraag 5a & $95 \%$ & $100 \%$ & $94 \%$ & $100 \%$ \\
Vraag 6 & $79 \%$ & $100 \%$ & $85 \%$ & $100 \%$ \\
Vraag 11 & $68 \%$ & $100 \%$ & $82 \%$ & $94 \%$ \\
Vraag 12 & $95 \%$ & $100 \%$ & $94 \%$ & $100 \%$ \\
Vraag 13 & $68 \%$ & $100 \%$ & $82 \%$ & $100 \%$ \\
Vraag 14 & $100 \%$ & $100 \%$ & $100 \%$ & \\
\hline
\end{tabular}

Tabel 6.8

Non-respons op de vragenlijst

\begin{tabular}{lrrrr}
\hline & \multicolumn{2}{c}{$\begin{array}{c}\text { Repons in telefonisch enquête } \\
\text { school }\end{array}$} & ROA & Respons in schriftelijke enquête \\
& & & & \\
& & & \\
\hline & & & & \\
totaal & & \\
Vraag 2b & $0 \%$ & $0 \%$ & $0 \%$ & $0 \%$ \\
Vraag 3b & $0 \%$ & $0 \%$ & $0 \%$ & $0 \%$ \\
Vraag 3c & $14 \%$ & $0 \%$ & $11 \%$ & $0 \%$ \\
Vraag 5b & $0 \%$ & $0 \%$ & $0 \%$ & $0 \%$ \\
Vraag 7 & $0 \%$ & $*$ & $0 \%$ & $100 \%$ \\
Vraag 8a & $50 \%$ & $0 \%$ & $20 \%$ & $100 \%$ \\
Vraag 9 & $50 \%$ & $0 \%$ & $20 \%$ & $0 \%$ \\
Vraag 10 & $50 \%$ & $0 \%$ & $20 \%$ & \\
& $50 \%$ & $0 \%$ & $20 \%$ & \\
\hline
\end{tabular}

Voor het beantwoorden van vragen die slechts in bepaalde gevallen van toepassing zijn, geniet een telefonische enquête door een onderzoeksinstituut duidelijk de voorkeur. Bij dergelijke vragen voldoet een schriftelijke enquête goed zolang het gaat om gesloten vragen (vraag $3 c, 7$ en 10), het invullen van aantallen (vraag $2 b$ en $3 b$ ) en het invullen van vervolgopleidingen (vraag 4b). Echter, het zodanig invullen van open vragen naar beroep (vraag 8a) en branche (vraag 9) dat deze tot op 4-digit volgens CBS-classificatie kunnen worden gecodeerd, is in deze schriftelijke proefmeting fout gegaan. Hierbij dient te worden gewezen op de zeer kleine aantallen betaald-werkende respondenten. 


\subsection{Consistentie bij de beantwoording}

In deze paragraaf wordt achtereenvolgens voor het schoolformulier en de vragenlijsten nagegaan hoe consistent deze zijn beantwoord.

\section{Schoolformulier}

Op het schoolformulier zijn alleen bij het schooltype van de vooropleiding de gevraagde gegevens in een aantal gevallen niet consistent verstrekt:

- 1 keer werd, in plaats van de antwoordcategorie 'LOM' aan te kruisen, de antwoordcategorie 'andere' aangekruist en bij 'nl:........' LOM ingevuld;

- 8 keer werd, in plaats van de antwoordcategorie '(I)VBO' aan te kruisen, de antwoordcategorie 'andere' aangekruist en bij 'nl:........' IVBO, VBO of LTS ingevuld;

- 1 keer werd, in plaats van de antwoordcategorie 'buitenlandse opleiding' aan te kruisen, de antwoordcategorie 'andere' aangekruist en bij 'nl:.......' een buitenlandse opleiding vermeld;

- 2 keer werd, in plaats van de antwoordcategorie 'andere' aan te kruisen, de antwoordcategorie 'buitenlandse opleiding' aangekruist terwijl het bleek te gaan om de internationale schakelklas;

- 2 keer werd bij de antwoordcategorie 'andere, $\mathrm{nl}$ :......' ingevuld dat de vooropleiding niet bekend was.

Gelukkig kunnen de bovengenoemde inconsistenties bij het invullen van de vooropleiding tijdens de datacontrole worden opgespoord en hersteld (tabel 7.1 in paragraaf 7.1 vermeldt de verdeling van de respondenten naar gecleande vooropleiding). Het verdient overigens aanbeveling om in de toekomst niet te vragen naar de 'vooropleiding' maar naar de 'laatst gevolgde vooropleidingen' aan de antwoordcategorieën een categorie 'internationale schakelklas' en een categorie 'onbekend' toe te voegen.

Vragenlijsten

De consistentie bij de beantwoording van de vragenlijst is het beste gewaarborgd bij een telefonische enquête door een onderzoeksinstituut. Tabel 6.9 laat zien dat telefonisch enquêteren door de eigen school en een schriftelijke enquête elkaar niet ontlopen wat betreft het aantal keren dat een vraag niet consistent wordt beantwoord. 
Tabel 6.9

Analyse van niet consistent beantwoorde vragen in de vragenlijst

\begin{tabular}{|c|c|c|c|}
\hline $\begin{array}{l}\text { Vraag } \\
\text { nummer }\end{array}$ & Wijze bevraging & $\mathrm{N}$ keren niet & $\begin{array}{l}\text { Opmerkingen } \\
\text { consistent } \\
\text { beantwoord }\end{array}$ \\
\hline \multirow[t]{2}{*}{1} & Telefonisch school & 1 & $\begin{array}{l}\text { Vermeldt als andere gevolgde } \\
\text { IVBO-opleiding 'weet- ik niet } \\
\text { meer' }\end{array}$ \\
\hline & $\begin{array}{l}\text { Telefonisch ROA } \\
\text { Schriftelijk }\end{array}$ & $\begin{array}{l}0 \\
2\end{array}$ & $\begin{array}{l}\text { Vermelden als andere gevolgde } \\
\text { IVBO-opleiding hun huidige } \\
\text { opleiding. }\end{array}$ \\
\hline \multirow[t]{2}{*}{2} & Telefonisch school & 1 & $\begin{array}{l}\text { Bij vraag } 2 \mathrm{~b} \text { wordt aantal } \\
\text { maanden werkloos ingevuld, } \\
\text { terwijl bij vraag } 2 \mathrm{a} \text { wordt } \\
\text { aangegeven na de opleiding } \\
\text { niet werkloos te zijn geweest. }\end{array}$ \\
\hline & $\begin{array}{l}\text { Telefonisch ROA } \\
\text { Schriftelijk }\end{array}$ & $\begin{array}{l}0 \\
0\end{array}$ & \\
\hline \multirow[t]{2}{*}{3} & Telefonisch school & 2 & $\begin{array}{l}\text { Geven bij vraag } 3 a \text { aan geen } \\
\text { betaald werk te hebben, maar } \\
\text { vullen bij vraag } 3 \mathrm{~b} \text { wel het aan- } \\
\text { tal uren in zij betaald-werken. }\end{array}$ \\
\hline & $\begin{array}{l}\text { Telefonisch ROA } \\
\text { Schriftelijk }\end{array}$ & $\begin{array}{l}0 \\
4\end{array}$ & $\begin{array}{l}\text { Geven bij vraag } 3 a \text { aan betaald } \\
\text { werk te hebben, mogen } \\
\text { derhalve vraag } 3 c \text { niet } \\
\text { beantwoorden, maar vullen } \\
\text { desondanks bij vraag } 3 c \text { in dat } \\
\text { zij geen werk willen hebben. }\end{array}$ \\
\hline 5 & $\begin{array}{l}\text { Telefonisch school } \\
\text { Telefonisch ROA } \\
\text { Schriftelijk }\end{array}$ & $\begin{array}{l}0 \\
0 \\
1\end{array}$ & $\begin{array}{l}\text { Vult bij vraag } 5 \mathrm{~b} \text { de reguliere } \\
\text { opleiding van vraag } 4 \mathrm{~b} \text { in. }\end{array}$ \\
\hline \multirow[t]{2}{*}{$3 \mathrm{t} / \mathrm{m} 6$} & Telefonisch school & 1 & $\begin{array}{l}\text { Huidige situatie onbekend, } \\
\text { want vult in: } \\
\text { - geen betaald werk te hebben, } \\
\text { - niet op zoek te zijn naar } \\
\text { betaald werk, } \\
\text { - niet in het leerlingwezen of } \\
\text { militaire dienst te zitten, } \\
\text { maar vult niet in al dan niet } \\
\text { scholier te zijn. } \\
\text { Vult in betaald werk te hebben } \\
\text { én scholier te zijn én in het } \\
\text { leerlingwezen te zitten en in } \\
\text { militaire dienst te zitten. De } \\
\text { huidige bezigheid van deze } \\
\text { schoolverlater is in de data- } \\
\text { cleaning als militaire dienst } \\
\text { gecodeerd. }\end{array}$ \\
\hline & $\begin{array}{l}\text { Telefonisch ROA } \\
\text { Schriftelijk }\end{array}$ & $\begin{array}{l}0 \\
0\end{array}$ & \\
\hline
\end{tabular}




\section{Toelichting bij vraag 1}

Twee schriftelijke respondenten hadden vraag 1 niet goed begrepen want zij vermelden als andere opleiding hun huidige opleiding. Wellicht dat het laatste kan worden voorkomen door te vragen naar de opleiding die men vorig schooljaar heeft verlaten in plaats van de opleiding die men vorig schooljaar heeft gevolgd.

Toelichting bij vraag $3 \mathrm{t} / \mathrm{m} 6$

Deze vragen dienen om de huidige situatie van de schoolverlaters te meten. Zeven keer $(14 \%)$ is de combinatie betaald werk én scholier ingevuld en twee keer (4\%) de combinatie scholier én leerlingwezen. In de datacleaning zijn scholieren die minder dan 12 uur per week betaald-werken als scholier gecodeerd; scholieren die tenminste 12 uur per week betaald-werken zijn als betaald-werkenden gecodeerd. De huidige bezigheid van schoolverlaters die hebben ingevuld scholier te zijn én in het leerlingwezen te zitten, is in de datacleaning gesteld op leerlingwezen. 


\section{Arbeidsmarktpositie van de respondenten}

In dit hoofdstuk worden, slechts bedoeld als voorbeeld, enkele resultaten gepresenteerd met betrekking tot de in de proefenquête gemeten arbeidsmarktpositie van de geënquéteerde schoolverlaters van het IVBO. Eerst worden in paragraaf 7.1 de respondenten beschreven aan de hand van een aantal achtergrondkenmerken. Vervolgens wordt in paragraaf 7.2 de kans op werk van de geënquéteerde IVBOschoolverlaters in kaart gebracht. Voor de schoolverlaters die verder zijn gaan leren, wordt in paragraaf 7.3 aangegeven naar welke vervolgopleidingen zij zijn doorgestroomd. Tot slot wordt in paragraaf 7.4 kort ingegaan op het werk van de respondenten die zijn gaan werken. Met nadruk wordt erop gewezen dat de hieronder gepresenteerde onderzoeksresultaten slechts exemplarische waarde hebben.

\subsection{Samenstelling onderzoekspopulatie}

In tabel 7.1 worden de respondenten beschreven aan de hand van een aantal persoonskenmerken, kenmerken van de genoten vooropleiding en kenmerken van de gevolgde IVBO-opleiding. Deze achtergrondkenmerken van de onderzoekspopulatie zijn allen gemeten met behulp van het Schoolformulier.

\section{Persoonskenmerken}

Tabel 7.1 laat zien dat de respondenten overwegend bestaan uit Nederlandse vrouwen. De gemiddelde leeftijd bij het verlaten van het IVBO bedraagt 17 jaar.

Vooropleiding

Vrijwel alle IVBO'ers hebben vooropleidingen of gedeelten van vooropleidingen (bijvoorbeeld alleen de brugklas) gevolgd, die geen formeel einddiploma kennen. Om deze reden beschikken de bevraagde IVBO-schoolverlaters niet over additionele, formele kwalificaties in de vorm van een diploma van een vooropleiding.

\section{Gevolgde IVBO-opleiding}

De meeste respondenten hebben een IVBO-opleiding in de verzorgende sector gevolgd en de IVBO-opleiding met diploma afgesloten. De gediplomeerden hebben er gemiddeld drie jaar over gedaan om de opleiding te voltooien. Vergeleken met de voortijdige schoolverlaters hebben de gediplomeerde IVBO'ers vaker vakken op een hoger niveau gevolgd. 
Tabel 7.1

Persoonskenmerken, vooropleiding en gevolgde IVBO-opleiding van de respondenten

\section{Persoonskenmerken}

Gemiddelde leeftijd bij schoolverlaters

17,3 jaar

Geslacht:

- man

- vrouw

Nationaliteit:

- Nederlandse

- andere

\section{Vooropleiding}

Schooltype vooropleiding:*

- basisschool

- LOM

- MLK

- VSO-MLK

- (I)VBO

- IVO-MAVO

- buitenlandse opleiding

Diplomabezit vooropleiding:

- nee

- niet van toepassing

\section{Gevolgde IVBO-opleiding}

Gevolgde opleidingsrichting:

- textielverwerkende beroepen, theorie $\quad 16 \%$

- textielverwerkende beroepen, praktijk $19 \%$

- uiterlijke verzorging

- verzorgende beroepen

$39 \%$

- subtotaal verzorgende sector $\quad 80 \%$

- bloemopleidingen $\quad 7 \%$

$\begin{array}{ll}\text { - plantopleidingen } & 13 \% \\ \text { - subtotaal agrarische sector } & 20 \%\end{array}$

IVBO-diploma behaald:

- ja

$79 \%$

- nee

$21 \%$

\begin{tabular}{lccc}
\hline & Totaal & Gediplomeerden & Ongediplomeerden \\
Gemiddelde studieduur & 2,8 jaar & 3,0 jaar & 1,9 jaar \\
Gemiddeld aantal gevolgde vakken: & 4,5 & & \\
- op A-niveau & 2,7 & 4,4 & 5,0 \\
- op B-niveau & 3,8 & 3,7 & 3,0 \\
- op C-niveau & 0,5 & 0,5 & 0 \\
- op D-niveau & &
\end{tabular}

* Na datacleaning.

** In navolging van de RUBS-enquête zijn de voortijdige schoolverlaters uit het eerste en tweede schooljaar niet meegenomen in de proefmeting. 


\subsection{Kans op werk}

De kans op werk wordt in deze paragraaf geïndiceerd door de duur van de intredewerkloosheid en de werkloosheid op het moment van de enquête.

\section{Duur intredewerkloosheid}

De totale duur van de werkloosheid(sperioden) tijdens de arbeidsmarktintrede geeft een indicatie van de mate waarin de intrede op de arbeidsmarkt meer of minder succesvol is verlopen. Aan de respondenten is gevraagd of men na de IVBOopleiding werkloos is geweest en zo ja, hoeveel maanden men in totaal werkloos is geweest na de IVBO-opleiding. Een kwart (24\%) van de respondenten geeft aan dat zij na de IVBO-opleiding ooit werkloos zijn geweest (gediplomeerden 20\%; voortijdige schoolverlaters $33 \%$ ). De totale duur van de werkloosheid(sperioden) tussen het moment van schoolverlaters en het moment van enquêteren bedraagt gemiddeld 5,1 maand (gediplomeerden gemiddeld 5,0 maanden; voortijdige schoolverlaters gemiddeld 5,5 maanden).

\section{Werkloosheid op enquêtemoment}

Schoolverlaters zijn werkloos indien zij op het moment van de enquête:

- zijn ingeschreven bij het Arbeidsbureau (vraag 13), én

- $\quad$ een baan van tenminste 12 uur per week willen hebben (vraag 3c), én

- op het enquêtemoment geen betaald werk voor tenminste 12 uur per week hebben (vraag $3 a$ en $3 b$ ), én

- beschikbaar zijn voor een baan. d.w.z. binnen twee weken kunnen beginnen (vraag 12).

Aldus gedefinieerd, blijken slechts twee respondenten (4\%) op het moment van de enquête werkloos te zijn.

\subsection{Vervolgonderwijs na schoolverlaters}

Op het moment van de enquête volgt de meerderheid van de respondenten verder onderwijs, namelijk $63 \%$ als scholier en $6 \%$ als leerling in het kader van het leerlingwezen. De gediplomeerde IVBO'ers volgen vaker verder onderwijs dan de voortijdige schoolverlaters. Van de gediplomeerde schoolverlaters volgt $68 \%$ verder onderwijs als scholier en $8 \%$ als leerling in het kader van het leerlingwezen; bij de voortijdige schoolverlaters is dit respectievelijk $29 \%$ en $14 \%$. De geënquéteerde IVBO'ers stromen meestal door naar het MDGO en het (K)MBO. Tabel 7.2 geeft hiervan een beeld. 
Tabel 7.2

Schooltype en richting vervolgonderwijs

\begin{tabular}{lr} 
Levensschool & $5 \%$ \\
& \\
IVBO, verzorging & $5 \%$ \\
VBO, schilderen en reclametekenen & $5 \%$ \\
Leerlingwezen: economisch/administratief & $5 \%$ \\
Leerlingwezen: distributie & $9 \%$ \\
MDGO, oriëntatie- en schakelklas & $9 \%$ \\
MDGO, verzorging & $9 \%$ \\
MDGO, assistenten gezondheidszorg & $5 \%$ \\
MDGO, uiterlijke verzorging & $9 \%$ \\
MBO, oriëntatie- en schakelklas & $9 \%$ \\
(K)MBO, verzorging & $18 \%$ \\
(K)MBO, agrarisch & $9 \%$ \\
AOC, bloemschikken & $5 \%$ \\
\hline
\end{tabular}

\subsection{Werken na schoolverlaten}

Drie respondenten zijn betaald gaan werken in het kader van het leerlingwezen en 12 buiten het leerlingwezen. Van deze 15 werkende schoolverlaters hebben er 9 de vraag naar de aard van het dienstverband (vraag 7) beantwoord. Van deze 9 werkende respondenten hadden 2 een baan in het kader van het leerlingwezen ${ }^{11}, 2$ werkten via het uitzendbureau, 3 in loondienst bij een werkgever en 2 in een ander dienstverband.

Acht van de 15 werkende schoolverlaters hebben tot op 4-digit codeerbaar aangegeven welk beroep zij uitoefenen en in welke branche zij werkzaam zijn. Van deze 8 respondenten werken er:

- 2 als hulparbeider in de tuinbouw;

- 2 als interieurverzorgster in de horeca;

- 1 als controleur/keurder in de procesindustrie;

- 1 als kassamedewerker in de detailhandel voedings-/genotmiddelen, algemeen assortiment;

- 1 als gezinshulp in de gezinszorg;

- 1 als bloemschikker in de detailhandel bloemen/planten.

De vraag naar de aansluiting tussen de vroegere IVBO-opleiding en het huidige werk is door 9 van de 11 betaald-werkende schoolverlaters beantwoord. Van deze 9

11. Na datacleaning, want van de twee respondenten in het leerlingwezen die deze vraag hebben beantwoord, gaf de ene aan via een uitzendbureau en de andere in gewone loondienst te werken. 
respondenten zijn er 4 van mening dat het werk goed past bij hun vroegere opleiding; 4 respondenten beoordelen de aansluiting als 'gaat wel' en slechts één respondent vindt dat het werk slecht past bij de vroegere opleiding. De werkende IVBO'ers zijn dus in overgrote meerderheid (matig) tevreden over de aansluiting opleiding-werk. 


\section{Conclusies}

In de proefmeting zijn twee instrumenten getest waarmee de bestemming van gediplomeerde én ongediplomeerde IVBO-schoolverlaters kan worden gemeten, namelijk een kort schriftelijk vragenformulier en een telefonische enquête. Teneinde deze schriftelijke en telefonische enquêtes zo beknopt mogelijk te maken, is een schoolformulier opgesteld aan de hand waarvan de schooladministratie of de decaan vóóraf de benodigde achtergrondgegevens over de IVBO'ers kan noteren.

Gebleken is dat het invullen van schoolformulieren, waarmee achtergrondkenmerken van leerlingen worden gemeten, de scholen veel tijd kost en hun bereidheid vermindert om aan een dergelijk onderzoek mee te werken. Bij een sterk verkort schoolformulier zullen scholen wellicht eerder bereid zijn hun medewerking te verlenen. Ook wanneer een school reeds participeert in een uitstroomonderzoek als RUBS of het Schoolverlaters Volgsysteen (SVS) van de Nederlandse Vereniging van Schooldekanen (NVS), zal zij niet genegen zijn om daarnaast aan een aparte meting onder IVBO'ers deel te nemen. Dit probleem zou kunnen worden ondervangen door de IVBO-meting onder te brengen in een geïntegreerde RUBS-SVS meting. Met betrekking tot het laatste dient te worden vermeld dat het ROA in 1995/'96 is betrokken geweest in een pilotproject om te komen tot een integratie van SVS en de RUBS-enquête. Beide systemen proberen zicht te krijgen op de ervaringen van schoolverlaters op de arbeidsmarkt of in het vervolgonderwijs. RUBS doet dit door een grootschalige landelijke meting op één meetmoment; in het SVS benadert de dekaan de schoolverlater op enkele momenten om daarmee voortijdige uitval uit het vervolgonderwijs te voorkomen. Door een integratie kan de persoonlijke benadering uit het SVS en de landelijke enquête van RUBS worden gecombineerd. Naast de uitgebreide schriftelijke meting in het kader van RUBS benadert de school de leerling nog een paar keer, zodat een goed beeld ontstaat van de ontwikkeling van de schoolverlater. Een beperkt aantal vragen uit de uitgebreide RUBS-vragenlijst worden dan door de dekaan nog eens aan de schoolverlaters gesteld.

Persoonsgegevens, gegevens over de vooropleiding, gegevens over de gevolgde IVBO-opleiding en gegevens over de eerste bestemming na schoolverlaters hoeven niet aan de schoolverlaters zelf te worden gevraagd, aangezien deze gegevens vrijwel steeds door de scholen kunnen worden verstrekt. Echter, de betrouwbaarheid van het schoolformulier schiet tekort als het gaat om het vaststellen van de huidige bestemming van de schoolverlaters, in het bijzonder wanneer deze zijn doorgestroomd naar de arbeidsmarkt. Hiervoor is een schriftelijke enquête of een telefonische enquête (mits deze ook in de avonduren plaatsvindt) vereist.

Een telefonische bevraging door de eigen school leidt door de bank genomen tot een even hoge respons als een schriftelijke enquête. De hoogte van de respons bij een telefonische bevraging door de eigen school varieert echter sterk tussen 
scholen. Overigens wijken schoolverlaters zonder telefoon of met een geheim telefoonnummer nauwelijks af van de schoolverlaters die in beginsel wel telefonisch kunnen worden bereikt, wat betreft geslacht, nationaliteit, opleidingssector en diplomabezit.

Wat de selectiviteit van de respons betreft, is onder meer naar voren gekomen dat mannelijke respondenten bij een telefonische benadering door de scholen zijn ondervertegenwoordigd. Dit zal samenhangen met de bevinding dat de mannelijke respondenten vier keer zo vaak een betaalde baan blijken te hebben dan de vrouwelijke respondenten en derhalve veel vaker na herhaald bellen, tenminste als dit niet ook in de avonduren gebeurt, telefonisch niet kunnen worden bereikt. Bij een schriftelijke enquête blijken de verschillen tussen populatiekenmerken en kenmerken van de respondenten door de bank genomen het kleinst te zijn.

Wat de hoogte van de respons per vraag betreft, voldoet een schriftelijke enquête even goed als een telefonische enquête door een onderzoeksinstituut. Een telefonische bevraging door de eigen school voldoet wat dit betreft iets minder, aangezien dekanen de verstrekte antwoorden niet steeds volledig registreren. Bij een telefonische enquête door een onderzoeksinstituut is de consistentie bij de beantwoording van de vragenlijst het beste gewaarborgd.

Gezien vooral de representativiteit van de respons geniet een schriftelijke meting de voorkeur boven een telefonische benadering. Een schriftelijke meting, aangevuld met een verkort schoolformulier zou bij voorkeur moeten worden ondergebracht in een geïntegreerde RUBS-SVS meting. In de eerste plaats zal dit de bereidheid van scholen vergroten om mee te werken, in het bijzonder wat het invullen van de schoolformulieren betreft. In de tweede plaats gaat het bij IVBO'ers om kleine aantallen, individueel begeleide leerlingen waarop de sterk op individuele schoolverlaters gerichte SVS-enquête goed zou aansluiten. Integratie met RUBS impliceert een schriftelijke benadering, echter met een speciaal voor IVBO'ers sterk vereenvoudigd en verkort vragenformulier. Uit het oogpunt van de hoogte van de respons en de hoogte van de respons per vraag blijkt een schriftelijke benadering immers nagenoeg even goed te voldoen als een telefonische benadering. Wat de selectiviteit van de respons betreft, voldoet een schriftelijke benadering beter dan een telefonische benadering. Overigens zou het vragenformulier vooral gericht moeten zijn op het in kaart brengen van het vervolgonderwijs, gezien de bevinding dat de overgrote meerderheid van de IVBO'ers doorstroomt naar vervolgopleidingen. De vragen naar het beroep en de branche zouden derhalve eventueel kunnen vervallen. De vragen met betrekking tot het zoeken naar werk (vraag $11 \mathrm{t} / \mathrm{m} \mathrm{13}$ ) moeten worden vereenvoudigd.

Hoewel de in hoofdstuk 7 gepresenteerde onderzoeksresultaten slechts exemplarische waarde hebben, tekent zich een aantal verschillen tussen gediplomeerde en 
ongediplomeerde IVBO'ers af. Zo komt naar voren dat gediplomeerde IVBO'ers vaker vakken op een hoger niveau hebben gevolgd, vaker doorstromen naar vervolgonderwijs en minder vaak en korter werkloos zijn. 



\section{Literatuur}

Coolen, W.H.M. (1993), Scholen gespiegeld: enquêteresultaten instroombelemmerende en instroombevorderende factoren t.b.v. VBO school A, project Instroombevordering Beroepsonderwijs Limburg, RDC Limburg, Maastricht.

Gortzak, K.J.J.M. (1990), Voortijdige uitstroom oud-VSO-leerlingen uit de arbeidsmarkt, oorzaken/redenen; een kwalitatief onderzoek in de regio Amstelland en de Meerlanden. Onderzoeksopzet, Leids Interdisciplinair Centrum voor Onderwijsresearch, Rijksuniversiteit Leiden.

Gortzak, K.J.J.M., H.G.J. van der Linde (1991), VSO (Z)MLK in perspectief. Een onderzoek naar de uitstroom van het VSO-(Z)MLK, De Lier: Academisch Boeken Centrum.

Hooren, R. van (1993), Schoolverlaters van het VBO-A en IVBO: omvang en bestemming, Provinciaal Steunpunt Werkgelegenheid, Den Bosch.

Kockelkorn, G.M.K. (1 993), Toespraak ter gelegenheid van de presentatie van het evaluatie verslag van het VSO-/MLK-project Maastricht, Maastricht.

Ministerie van Onderwijs en Wetenschappen (1993), Referentieraming 1993, Zoetermeer

Ministerie van Onderwijs en Wetenschappen (1993), Inrichtingsbesluit VWO, HAVO,MAVO, VBO, Zoetermeer.

RBA Zuid-Limburg, De praktijk, verslag van het VSO/MLK project Maastricht, RBA ZuidLimburg, Gemeente Maastricht, Coördinatiepunt PBVE, Maastricht.

RDC-Limburg (1993), Uitstroom uit het VSO-MLK en ZMOK in Limburg, in: Afstemming VSOArbeidsmarkt, Nieuwsbrief nr. 2, mei 1993.

Roes, L. (1993), Toespraak ter gelegenheid van de presentatie van het evaluatieverslag van het VSO-MLK-project Maastricht, Maastricht.

Segers, J.H.G. (1983), Sociologische onderzoeksmethoden, deel 1: inleiding tot de structuur van het onderzoeksproces en tot de methoden van dataverzameling, Van Gorcum, Assen.

Smoorenburg, M.S.M. van, R.K.W. van der Velden, P.J.E. van de Loo, (1994), Schoolverlaters op de arbeidsmarkt, Registratie van de Uitstroom en Bestemming van Schoolverlaters van het schooljaar 1991/1992, Stichting Landelijk Dienstverlenend Centrum voor de Studie- en Beroepskeuzevoorlichting (LDC), Leeuwarden.

Staatsblad (1993), Wet op het voortgezet onderwijs, 1993-666, Den Haag.

Universiteit Utrecht (1 993), Persberichten 16-30/11.

Veldt, M.C. van der (1993), Twee VSO-ZMOK-scholen nader bekeken. Een explorerend onderzoek naar zowel de in- en uitstroom van twee VSO-ZMOK-scholen in Limburg, als naar de manier waarop binnen deze scholen gestalte wordt gegeven aan de stage, Leids Interdisciplinair Centrum voor Onderwijsresearch, Rijksuniversiteit Leiden.

Verkuijlen, P. (1 993), Toespraak ter gelegenheid van de presentatie van het evaluatieverslag van het VSO-/MLK-project Maastricht, Maastricht.

Wieling, M.H., P.J.E. van de Loo, R.K.W. van der Velden (1993), Waar komen onze schoolverlaters terecht, De uitstroom en bestemming van het schooljaar 1990/1991, Stichting Landelijk Dienstverlenend Centrum voor de Studie- en Beroepskeuzevoorlichting (LDC), Leeuwarden. 



\section{Bijlage 1 Lijst van gesprekspartners}

IVBO

R. El Namaki, RDC-Limburg

J. Finders, decaan Technisch College Maasland, Maastricht

T. Helvoirt, decaan De Molenbossen, school voor basisvorming en beroepsonderwijs, Venlo

T. Pleunis, decaan Scholengemeenschap Trajectum, Maastricht

vso

H. Beterams, RDC-Limburg

R. El Namaki, RDC-Limburg

K. Gortzak, onderzoeker LICOR

J. Klinkers, directeur VSO-(Z)MLK-school/Landelijk Werkverband VSO-MLK

H. van der Linde, onderzoeker LICOR

J. Meulenbeld, beleidsmedewerker RBA Zuid-Limburg

G. Moubax, consulent arbeid Sociaal-Pedagogische Dienst

P. Verkuilen, sectormanager Provinciaal Steunpunt Werkgelegenheid NoordBrabant/coördinator VSO-MLK van het Landelijk Overleg Werkloosheid

J. Vaasen, stagedocent VSO-ZMOK-school 



\section{Bijlage 2 Gesprekspunten interviews met school- decanen IVBO}

Instrumentarium voor registratie van de uitstroom en bestemming van schoolverlaters van het IVBO

Doel:

Het periodiek (jaarlijks) en op betrouwbare wijze in kaart brengen van de uitstroom en bestemming (op arbeidsmarkt, in vervolgonderwijs of anderszins) van gediplomeerde en ongediplomeerde schoolverlaters van het IVBO (VBO-a/b).

Afbakening onderzoeksgroep:

IVBO-schoolverlaters (gediplomeerd/ongediplomeerd; alle niveau's (alb)?).

Dataverzameling:

- schriftelijke vragenlijst(en);

- algemene en/of (vervolg) voor vervolgonderwijs/werk;

- telefonische enquête (verschillende talen mogelijk);

- interview (verschillende talen mogelijk);

- combinatie van schriftelijke/telefonische enquête en interview.

Structuur

open / gesloten.

Respondenten (wie verstrekt gegevens?):

- IVBO-schoolverlaters zelf;

- decaan/docent IVBO;

- ouders;

- werkgevers;

- decaan/docent vervolgopleiding;

$-\ldots$

Enquêtemoment:

- ca. 1 jaar na afstuderen (voorjaar); zoals bij RUBS;

- of eerder (half jaar na afstuderen) of later (anderhalf jaar na afstuderen).

Informatie / enquête vooraf in laatste schooljaar.

(voor informatie, wennen aan idee en hulp door docent mogelijk; bepaalde retrospectieve vragen vermijden)

- verwachtingen t.a.v. werk/vervolgopleiding/ ..

* Wat wil je na opleiding gaan doen? Waarom?

* Wanneer ben/ga je naar werk (gaan) zoeken? 
- laatst bekende adres (+ toevoegen adreswijziging).

Onderwerpen (zonder of juist met toelichting; zie vragenlijst RUBS):

! A korte controlevragen over opleiding (soort, wel/niet diploma, jaar start en einde), sexe, leeftijd, etniciteit

! A reden voortijdig schoolverlaters (alleen voor ongediplomeerden)

! A aantal maanden werkloos na verlaten opleiding

! A bezigheden op enquêtemoment: leerlingwezen, scholier, betaald werk, onbetaald werk, huishouden, werkloos, militaire/vervangende dienstplicht, anders:

! A waarom bepaalde bestemming gekozen 1 in terecht gekomen?

! S/A vervolgopleiding (naar allen na opleiding vragen of alleen ten tijde van meting?)

- W eerste baan en/of wanneer in baan begonnen?

- W hoe aan baan gekomen?

- W soort dienstverband

! W aanstellingsduur

! W beroep en werkzaamheden

! W naam/soort organisatie, afdeling

- W plaats bedrijf

- W personeelsomvang bedrijf

! W minimaal vereiste opleidingsniveau

- W vereiste opleidingsrichting

! W wekelijkse arbeidsduur

! W bruto/netto maandloon

! A op zoek naar (ander) werk; zo ja, hoe en voor $\geq 12$ uur per week?

! A als werkzoekende ingeschreven bij arbeidsbureau

! A binnen 2 weken beschikbaar voor (ander) werk

! A algemene beoordeling aansluiting opleiding en huidige bezigheden

- A beoordeling aspecten

! A open vraag: waaraan meer aandacht schenken tijdens IVBO

! A opnieuw zelfde opleiding kiezen (qua richting)

- A aanvullende opleiding / cursus

- A waarom aanvullende opleiding / cursus

- A ook niet anonieme resultaten aan school?

! A naam/adres

!

Legenda:

$A=$ allemaal $\quad !=$ belangrijke vraag (voorstel $R O A$ )

$\mathrm{W}=$ werkenden $\quad-\quad=$ minder belangrijke vraag (voorstel ROA) 
$S$ = scholier

Benodigde informatie vooraf van IVBO

(kan en wil school volgende informatie leveren?

noodzakelijk dat dit nogmaals aan respondent wordt gevraagd?)

- naam, adres (ouderlijk en/of schoolverlater);

- telefoonnummer:

- sexe;

- leeftijd;

- geslacht;

- etniciteit (bijv. i.v.m. telefonische enquête);

- thuiswonend (bij ouders) / uitwonend (wel/niet zelfstandig);

- eigen kinderen;

- gevolgde opleiding IVBO (richting en niveau vakken);

- school en laatst gevolgde klas;

- vooropleiding;

- doubleren / van andere school;

- wanneer met opleiding (aan deze school) begonnen;

- wanneer opleiding (aan deze school) verlaten (met/zonder diploma);

- aan zelfde/andere school doorgegaan met (andere) opleiding; naam opleiding en school.

Voonwaarden voor deelname IVBO-school:

- kosten;

- organisatie;

- begeleiding van school;

- produkt (instellingsrapportage / landelijk rapport of .... ).

Kosten en financiering 



\section{Bijlage 3 Invulanalyse vragenlijsten RUBS 1993}

\begin{tabular}{|c|c|c|}
\hline Enquêtenummer & Vraag & Opmerking \\
\hline 023453 & 1 & Vraag $1 \mathrm{e}$ is niet ingevuld. \\
\hline 023458 & 1 & Vraag $1 \mathrm{f}$ is niet ingevuld. \\
\hline 023482 & 1 & Vraag $1 \mathrm{~b}$ en $1 \mathrm{c}$ zijn niet ingevuld. \\
\hline 023484 & 1 & Vraag $1 \mathrm{f}$ is niet ingevuld. \\
\hline 023487 & 1 & $\begin{array}{l}\text { Vraag 1d: Heb je een diploma van deze } \\
\text { opleiding? Hier wordt positief geantwoord. } \\
\text { Maar ook wordt vraag } 1 \mathrm{~h} \text { (waarom heb je } \\
\text { deze opleiding niet afgemaakt?) wordt } \\
\text { beantwoord. }\end{array}$ \\
\hline 023488 & 1 & Vraag $1 \mathrm{f}$ en $1 \mathrm{~g}$ zijn niet ingevuld. \\
\hline 023580 & 1 & $\begin{array}{l}\text { Bij vraag } 1 \mathrm{~d} \text { is geantwoord dat het diploma } \\
\text { behaald is. Maar ook vraag } 1 \mathrm{~h} \text { (waarom heb } \\
\text { je deze opleiding niet afgemaakt?) is } \\
\text { ingevuld. }\end{array}$ \\
\hline 023592 & 1 & $\begin{array}{l}\text { Het antwoord op vraag } 1 \mathrm{~d} \text { verwijst door naar } \\
\text { vraag } 1 \mathrm{e} . \text { Maar vraag } 1 \mathrm{e} \text { is niet ingevuld en } \\
\text { vraag } 1 \mathrm{~h} \text {, die niet ingevuld mocht worden, } \\
\text { wel. }\end{array}$ \\
\hline 004666 & 1 & Vragen $1 \mathrm{~b}$ en $1 \mathrm{f}$ zijn niet ingevuld. \\
\hline 004769 & 1 & Vraag $1 \mathrm{~b}$ is niet helemaal ingevuld. \\
\hline 004835 & 1 & Vraag $1 \mathrm{f}$ is niet ingevuld. \\
\hline 005241 & 1 & $\begin{array}{l}\text { Vraag } 1 \mathrm{~h} \text { is ingevuld, maar deze moet } \\
\text { overgeslagen worden. }\end{array}$ \\
\hline 005366 & 1 & Vraag $1 \mathrm{f}$ is niet ingevuld. \\
\hline 026143 & 1 & Vraag $1 \mathrm{~b}$ is niet helemaal ingevuld. \\
\hline 026164 & 1 & Vraag $1 \mathrm{~b}$ is niet helemaal ingevuld. \\
\hline 026173 & 1 & Vragen $1 b$ en 1c zijn niet ingevuld. \\
\hline 026189 & 1 & Vragen $1 \mathrm{~b}$ en $1 \mathrm{c}$ zijn niet ingevuld. \\
\hline 026204 & 1 & $\begin{array}{l}\text { Vragen } 1 \mathrm{~b} \text { en } 1 \mathrm{c} \text { zijn niet helemaal ingevuld } \\
\text { en vragen } 1 \mathrm{e} t / \mathrm{m} 1 \mathrm{~h} \text { zijn helemaal niet inge- } \\
\text { vuld. }\end{array}$ \\
\hline 026247 & 1 & Vraag $1 \mathrm{e}$ is niet ingevuld. \\
\hline 026250 & 1 & Vraag $1 \mathrm{f}$ is niet ingevuld. \\
\hline 006511 & 1 & Vraag $1 \mathrm{~b}$ is niet helemaal ingevuld. \\
\hline 006549 & 1 & $\begin{array}{l}\text { Bij vragen } 1 \mathrm{~b} \text { en } 1 \mathrm{c} \text { is klas/leerjaar niet inge- } \\
\text { vuld. }\end{array}$ \\
\hline 007023 & 1 & Vragen $1 \mathrm{~b}$ en $1 \mathrm{c}$ zijn niet ingevuld. \\
\hline 016959 & 1 & Vragen 1e en $1 \mathrm{f}$ zijn niet ingevuld. \\
\hline 017067 & 1 & Vraag $1 \mathrm{f}$ is niet ingevuld. \\
\hline
\end{tabular}


Vragen $1 \mathrm{~b}$ en $1 \mathrm{c}$ zijn niet ingevuld.

021374

021380

021409

021426

021490

021512

021544

021572

023420

005355

021490

023420

023420

023484

005272

026204

026228

021374

021409

021553

026228

005242

023480

Vraag $1 \mathrm{~g}$ is niet ingevuld.

Vragen $1 b$ en $1 c$ zijn niet ingevuld.

Vragen $1 b$ en $1 c$ zijn niet ingevuld.

Vraag $1 \mathrm{~b}$ is niet volledig ingevuld.

Vragen $1 b$ en $1 c$ zijn niet volledig ingevuld en vragen $1 \mathrm{~d}$ en $1 \mathrm{f}$ zijn niet ingevuld.

Vragen $1 \mathrm{~b}$ en $1 \mathrm{c}$ zijn niet ingevuld.

Vraag $1 \mathrm{~d}$ verwijst naar vraag $1 \mathrm{~h}$, maar vraag $1 \mathrm{f}$ en $1 \mathrm{~g}$ zijn ook ingevuld.

Vraag $1 \mathrm{~d}$ verwijst door naar vraag $1 \mathrm{~h}$, maar vragen $1 \mathrm{e}, 1 \mathrm{f}$ en $1 \mathrm{~g}$ zijn ook ingevuld.

Bij vraag $2 a$ is zowel optie 1 als optie 2 ingevuld.

Vragen $2 b$ en $2 c$ zijn ingevuld, terwijl deze moeten worden overgeslagen.

Vraag 2 is niet ingevuld.

Vraag 3a is niet ingevuld, moet optie 1 zijn.

Vanaf vraag $3 e$ moet doorgegaan worden naar vraag 7 , echter vraag 4 is ook ingevuld.

Vraag $3 a$ verwijst naar $3 b$, maar deze is niet ingevuld.

Bij vraag 3 wordt geantwoord dat hij in het llw zit en bij vraag 5 wordt als huidige opleiding het KMBO gegeven.

Vragen 3a, 6, 13, 14 en 16 zijn niet ingevuld, terwijl deze wel moeten worden ingevuld.

Vraag $3 d$ verwijst door naar vraag 13 , maar de vragen $4 \mathrm{t} / \mathrm{m} 12$ zijn ook ingevuld.

Vraag 3 is niet ingevuld.

Vragen $3 \mathrm{~b}$ en $3 \mathrm{c}$ zijn niet ingevuld.

Vragen $3 a$ en $3 b$ zijn niet ingevuld.

Vraag 3 is niet ingevuld.

Vragen $3 d$ en $3 e$ zijn ingevuld, terwijl deze moeten worden overgeslagen.

Vragen 4, 5 en 6 zijn wel ingevuld, hoewel de route van vraag $3 e$ meteen naar vraag 7 gaat. Vragen 4,5 en 6 zin ingevuld, terwijl deze moeten worden overgeslagen.

Vraag 4 verwijst door naar vraag 7. Maar er wordt pas weer iets ingevuld bij vraag 13. 


\begin{tabular}{|c|c|c|}
\hline 023592 & 4 & $\begin{array}{l}\text { Vragen } 4 \text { en } 6 \text { zijn ingevuld. Deze zouden } \\
\text { overgeslagen moeten worden. }\end{array}$ \\
\hline 004591 & 4 & $\begin{array}{l}\text { Vraag } 4 \text { is ingevuld, maar moet overgeslagen } \\
\text { worden. }\end{array}$ \\
\hline 004992 & 4 & $\begin{array}{l}\text { Vraag } 3 e \text { verwijst door naar vraag } 7 \text {. Echter } \\
\text { vragen } 4 \text { en } 6 \text { zijn ingevuld, terwijl deze moe- } \\
\text { ten worden overgeslagen. }\end{array}$ \\
\hline 026149 & 4 & $\begin{array}{l}\text { Vraag } 4 \text { is ingevuld, maar moet niet ingevuld } \\
\text { worden. }\end{array}$ \\
\hline 026167 & 4 & $\begin{array}{l}\text { Vraag } 4 \text { is ingevuld, terwijl deze niet moet } \\
\text { worden ingevuld. }\end{array}$ \\
\hline 026189 & 4 & $\begin{array}{l}\text { Vragen } 4,5 \text { en } 6 \text { zijn ingevuld, terwijl deze } \\
\text { niet ingevuld moeten worden. }\end{array}$ \\
\hline 006549 & 4 & $\begin{array}{l}\text { Vraag } 4 \text { is ingevuld, terwijl deze niet moet } \\
\text { worden ingevuld. }\end{array}$ \\
\hline 006555 & 4 & $\begin{array}{l}\text { Vragen } 4 \text { en } 6 \text { zijn ingevuld, terwijl deze niet } \\
\text { moeten worden ingevuld. }\end{array}$ \\
\hline 006868 & 4 & $\begin{array}{l}\text { Vragen } 4,5 \text { en } 6 \text { zijn ingevuld, terwijl deze } \\
\text { moeten worden overgeslagen. }\end{array}$ \\
\hline 017012 & 4 & $\begin{array}{l}\text { Vraag } 4 \text { is ingevuld, terwijl deze moet worden } \\
\text { overgeslagen. }\end{array}$ \\
\hline 017095 & 4 & $\begin{array}{l}\text { Vraag } 4 \text { is ingevuld, terwijl deze moet worden } \\
\text { overgeslagen. }\end{array}$ \\
\hline 021458 & 4 & $\begin{array}{l}\text { Vraag } 4 \text { is ingevuld, terwijl deze moet worden } \\
\text { overgeslagen. }\end{array}$ \\
\hline 021572 & 4 & $\begin{array}{l}\text { Vragen } 4,5 \text { en } 6 \text { zijn ingevuld, maar moeten } \\
\text { worden overgeslagen. }\end{array}$ \\
\hline 023462 & 6 & $\begin{array}{l}\text { Vanaf deze vraag moet doorgegaan worden } \\
\text { naar vraag } 7 \text {. Echter vanaf vraag } 14 \text { is pas } \\
\text { weer iets ingevuld. }\end{array}$ \\
\hline 005241 & 6 & $\begin{array}{l}\text { Vragen } 6 \text { en } 7 \text { zijn ingevuld, terwijl deze } \\
\text { moeten worden overgeslagen. Vragen } 13 \text { en } \\
14 \text { zijn niet ingevuld, terwijl deze wel moeten } \\
\text { worden ingevuld. }\end{array}$ \\
\hline 005275 & 6 & $\begin{array}{l}\text { Bij vraag } 6 \text { is zowel antwoord } 1 \text { als antwoord } \\
2 \text { ingevuld. }\end{array}$ \\
\hline 026235 & 6 & $\begin{array}{l}\text { Vraag } 6 \text { verwijst door naar vraag } 13 \text {, maar de } \\
\text { vragen } 13 \mathrm{t} / \mathrm{m} 17 \text { zijn niet ingevuld. }\end{array}$ \\
\hline 021490 & 6 & $\begin{array}{l}\text { Vraag } 6 \text { verwijst door naar vraag } 13 \text {, maar } \\
\text { vragen } 7,9 \text { en } 11 \text { zijn ook ingevuld. Op } \\
\text { vraag } 6 \text { wordt geantwoord dat hij geen } \\
\text { betaald werk heeft, maar toch worden een }\end{array}$ \\
\hline
\end{tabular}


023470

026228

006801

021409

021544

006555

006556

026149

005333

023487

023408

023420

023451

023463

004769

026231

026268

026573

006312

006511

006797

aantal vragen m.b.t. op betaald werk ingevuld.

Vraag 6 verwijst door naar vraag 13, maar de vragen 13 en 14 zijn niet ingevuld.

Vanaf vraag $7 \mathrm{t} / \mathrm{m} 16$ komt er vaak N.V.T. voor.

Vragen $7 \mathrm{t} / \mathrm{m} 17$ zijn niet ingevuld.

Vraag 7 is ingevuld, terwijl deze niet moet worden ingevuld.

Vragen 7,8 en 9 zijn niet volledig ingevuld.

Vragen 7, 10 en 11 zijn ingevuld, terwijl deze moeten worden overgeslagen.

Vraag $8 \mathrm{c}$ is niet ingevuld.

Vraag $8 \mathrm{c}$ is niet ingevuld.

Vraag $10 \mathrm{~b}$ is niet ingevuld.

Vragen 11, 12, 14 en 17 zijn niet ingevuld.

Vraag 12 is niet ingevuld.

Bij de vraag waarom hij niet binnen twee weken kan beginnen in een nieuwe baan, is ingevuld: vanwege opzegtermijn huidige baan. Echter bij vraag 6 wordt geantwoord dat hij naast zijn huidige opleiding geen betaald werk heeft.

Vanaf vraag $13 \mathrm{e}$ moet doorgegaan worden naar vraag 14 . Vraag 14 is echter overgeslagen.

Vraag 6 verwijst door naar vraag 13 . Er is echter pas weer iets ingevuld bij vraag 18.

Vraag 13a verwijst door naar vraag 14. Vraag 14 is niet ingevuld, maar vraag $13 \mathrm{c}$ wel. Vanaf vraag 15 wordt weer ingevuld.

Vragen $13 c$ en $13 d$ zijn ingevuld. Deze moeten worden overgeslagen.

Vragen $13 \mathrm{c}$ en $13 \mathrm{e}$ zijn ingevuld, terwijl deze moeten worden overgeslagen. Vragen 13d en $13 e$ zijn niet ingevuld.

Vraag 13a verwijst door naar vraag 14, maar vraag $13 \mathrm{c}$ is ook ingevuld.

Vraag 13 is niet ingevuld.

Vraag $13 \mathrm{c}$ is ingevuld terwijl deze niet moet worden ingevuld. deze niet moeten worden ingevuld. 


\begin{tabular}{|c|c|c|}
\hline 006801 & 13 & $\begin{array}{l}\text { Vragen } 13 \text { en } 14 \text { zijn niet ingevuld, terwijl dit } \\
\text { wel zou moeten. }\end{array}$ \\
\hline 017067 & 13 & $\begin{array}{l}\text { Vraag } 13 c \text { is ingevuld, terwijl deze moet } \\
\text { worden overgeslagen. }\end{array}$ \\
\hline 017095 & 13 & Vraag 13 is niet ingevuld. \\
\hline 017100 & 13 & Vraag 13,14 en 16 zijn niet ingevuld. \\
\hline 021380 & 13 & Vragen 13,14 en 17 zijn niet ingevuld. \\
\hline 021409 & 13 & Vragen 13 t/m 17 zijn niet ingevuld. \\
\hline 021426 & 13 & $\begin{array}{l}\text { Vraag } 13 c \text { is ingevuld, terwijl deze moet wor- } \\
\text { den overgeslagen. }\end{array}$ \\
\hline 021544 & 13 & $\begin{array}{l}\text { Vragen } 13 b, 13 c \text { en } 13 d \text { zijn ingevuld, terwijl } \\
\text { deze moeten worden overgeslagen. }\end{array}$ \\
\hline 021553 & 13 & Vragen 13 en $14 a$ zijn niet ingevuld. \\
\hline 004835 & 14 & $\begin{array}{l}\text { Vraag } 13 \text { a verwijst door naar vraag } 14 \text {, maar } \\
\text { vraag } 14 \text { is niet ingevuld. }\end{array}$ \\
\hline 026204 & 14 & Vraag 14 is niet ingevuld \\
\hline 021482 & 14 & $\begin{array}{l}\text { Vraag } 14 a \text { verwijst door naar vraag } 14 b \text { en } \\
14 c \text {. Deze laatste zijn niet ingevuld. }\end{array}$ \\
\hline 021490 & 14 & $\begin{array}{l}\text { Vraag } 14 \text { wordt positief ingevuld, maar de } \\
\text { opleiding, die hier wordt opgegeven komt } \\
\text { overeen met de huidige opleiding. }\end{array}$ \\
\hline 023487 & 15 & Vraag 15 is niet ingevuld. \\
\hline 006520 & 15 & $\begin{array}{l}\text { Vraag } 15 \text { is niet ingevuld, hoewel wel naar } \\
\text { deze vraag wordt verwezen. }\end{array}$ \\
\hline 021426 & 15 & Vragen 15,16 en 17 zijn niet ingevuld. \\
\hline 021490 & 15 & Vragen 15 en 16 zijn niet ingevuld. \\
\hline 021529 & 15 & Vragen 15 en 16 zijn niet ingevuld. \\
\hline 023482 & 16 & Vraag 16 is niet ingevuld. \\
\hline 005300 & 16 & Vragen 16 en 17 zijn niet ingevuld. \\
\hline 026143 & 16 & Vraag 16 is niet ingevuld. \\
\hline 026149 & 16 & Vraag 16 is niet ingevuld. \\
\hline 026247 & 16 & Vragen 16 en 17 zijn niet ingevuld. \\
\hline 006511 & 16 & Vraag 16 is niet ingevuld. \\
\hline 006810 & 16 & Vraag 16 is niet helemaal ingevuld. \\
\hline 007042 & 16 & Vraag 16 is niet ingevuld. \\
\hline 016959 & 16 & Vraag 16 is niet ingevuld. \\
\hline 021410 & 16 & Vragen 16 en 17 zijn niet ingevuld. \\
\hline 021463 & 16 & Vraag 16 is maar voor één punt ingevuld. \\
\hline 021485 & 16 & Vraag 16 is niet ingevuld. \\
\hline 021562 & 16 & Vraag 16 is maar voor één punt ingevuld. \\
\hline 021578 & 16 & Vraag 16 is niet ingevuld. \\
\hline 023487 & 17 & Vraag 17 is niet ingevuld. \\
\hline 005277 & 17 & Vraag 17 is niet ingevuld. \\
\hline
\end{tabular}




$\begin{array}{lll}005391 & 17 & \text { Vraag } 17 \text { is niet ingevuld. } \\ 026204 & 17 & \text { Vraag } 17 \text { is niet ingevuld. } \\ 006797 & 17 & \text { Vraag } 17 \text { is niet ingevuld. } \\ 016998 & 17 & \text { Vraag } 17 \text { is niet ingevuld. } \\ 021456 & 17 & \text { Vraag } 17 \text { is niet ingevuld. } \\ 021572 & 17 & \text { Vraag } 17 \text { is niet ingevuld. }\end{array}$

* Als er bij huidige opleiding of opleiding in het leerlingwezen iets staat ingevuld, wordt datzelfde in een aantal gevallen ook ingevuld bij een aanvullende opleiding. Een aantal keren wordt er ook bij huidige opleiding een opleiding in het leerlingwezen ingevuld en andersom.

* Het bruto maandloon wordt niet altijd ingevuld. In een aantal gevallen wordt het netto loon gegeven en soms het uurloon.

* Schoolverlaters hebben moeite met schrijven. Dit speelt met name bij de open vragen, maar vaak zijn hokjes ook 'kriebelig' aangekruist. De vele taalfouten maken het soms moeilijk om te begrijpen wat er staat. Dit kan met name een probleem zijn bij het coderen van beroepen en branches. 
Bijlage 4 RUBS-vragenlijst 1993 



\section{Vragenlijst RUBS 1993}

Beste oud-leerling,

Vorig jaar heb je de schoolopleiding afgesloten. Op basis van onze gegevens gaat het hierbij om de opleiding die hieronder afgedrukt staat. De school is zeer geïnteresseerd in de ervaringen die je daarna hebt opgedaan.

Ben je na het verlaten van de school gaan werken, of ben je een andere opleiding gaan volgen? Om op deze en andere vragen een antwoord te krijgen, willen we je vragen deze vragenlijst in te vullen.

De school werkt, evenals een groot aantal andere scholen in Nederland, in het kader van het project "Registratie van Uitstroom en Bestemming van Schoolverlaters" nauw samen met het regionale Adviescentrum voor Opleiding en Beroep en het Servicebureau Schoolverlatersinformatie.

Wanneer je deze vragenlijst invult draag je ertoe bij dat we beter zicht krijgen op de aansluiting van de opleiding op een vervolgopleiding of op een baan. De opleiding kan dan beter worden afgestemd op vervolgonderwijs of werk. De uitkomsten zijn ook heel belangrijk voor jongeren die nog een keuze moeten maken voor een bepaalde opleiding. Zij kunnen dan zien wat er mogelijk is na verschillende opleidingen. Het invullen van de vragenlijst kost je beslist niet veel tijd!

De ingevulde vragenlijst kun je zonder postzegel in de bijgevoegde antwoordenveloppe opsturen naar het Servicebureau Schoolverlatersinformatie. De formulieren komen dus niet meer terug op school.

De gegevens worden anoniem verwerkt. Dat wil zeggen, alle antwoorden worden opgeteld en niemand weet straks wat "jij" hebt ingevuld. Jouw eigen gegevens worden alleen aan de school doorgegeven wanneer je daar geen bezwaar tegen hebt. Dit kun je aangeven bij vraag 23. en opsturen.

Wij hopen dat je mee wilt werken en de vragenlijst zo spoedig mogelijk wilt invullen

Bedankt voor je medewerking!

Vul je antwoord op de stippellijntjes in of kruis een hokje aan. Het kan zijn dat je een aantal vragen niet hoeft in te vullen. Let daarom goed op naar welke vraag je wordt doorgestuurd. Bij de meeste vragen mag je maar één antwoord geven. Als je meer antwoorden mag invullen, hebben wij dit bij de vraag gezet.

\section{Opleiding vorig jaar (schooljaar 1991/1992)}

1 a. Hiernaast staat de dagopleiding die je vorig schooljaar (1991/1992) gevolgd hebt. Klopt dit?

b. Wanneer ben je met deze opleiding begonnen? En in welke klas of leerjaar?

c. Wanneer heb je deze opleiding verlaten? En in welke klas of leerjaar?

ja

nee, ik heb een andere dagopleiding gevolgd, namelijk:

maand : jaar: 19

klas/leerjaar:

maand : jaar: 19 ...........

klas/leerjaar: 
e. Heb je na het diploma nog een vijfde leerjaar of kopklas gedaan?

f. Hoeveel vakken heb je gedaan?

En op welk niveau?

nee

ja

nee

op A-niveau: ......... vakken

op B-niveau: ......... vakken

op C-niveau: ........ vakken

op D-niveau: ......... vakken

g. Heb je na het diploma nog een aanvullend

certificaat gehaald? (bijv. lassen)

1) ja

ja $\rightarrow$ ga door met vraag 2

$\rightarrow$ ga door met vraag 2

h. Waarom heb je deze opleiding niet afgemaakt?

om persoonlijke redenen (verhuisd, ziekte, e.d.)

2 vanwege de school (slechte begeleiding, problemen met de leerkrachten, e.d.)

3 vanwege de opleiding (sloot niet aan, te zwaar, e.d.)

omdat ik liever wilde werken

5 vanwege een andere reden, namelijk:

\section{Na de opleiding}

2 a. Wat wilde je vorig jaar direct na de opleiding gaan doen?

\section{werken $\quad \rightarrow \quad$ ga door met vraag $2 b$}

verder leren $\rightarrow \quad$ ga door met vraag 3

iets anders $\rightarrow \quad$ ga door met vraag 3

b. Wanneer ben je actief begonnen met werk zoeken?

maand : jaar: 19 ........... (je kunt ook al begonnen zijn met zoeken voordat je de opleiding verlaten hebt)

c. Hoeveel maanden ben je in totaal werkloos geweest sinds je de opleiding verlaten hebt?

: maanden

( vul ' 0 ' maanden in wanneer je niet werkloos bent geweest)

\section{Huidige bezigheden}

3 a. Volg je op dit moment een opleiding in: het leerlingstelsel (bijv. SOM, VEV, INNOVAM) of $\quad \rightarrow$ nee $\quad \rightarrow \quad$ ga door met vraag 4 - een in-service opleiding in de verpleging of verzorging (bijv. A-verpleging of ziekenverzorging)?

b. Welke opleiding in het leerlingstelsel/in-service volg je op dit moment?

(bijv. voor automonteur, installateur, ziekenverzorgende, A-verpleegkundige)

c. Alléén voor personen in het leerlingwezen Hoe heet het leerlingstelsel? (bijv. ECABO, INNOVAM, SOM, VEV, OVDB)

d. Heb je naast de opleiding op school ook werk of een stage?

e. Krijg je voor dit werk of de stage loon of alleen maar een onkostenvergoeding?

\begin{tabular}{|c|c|c|c|}
\hline$\square$ & werk & $\rightarrow$ & ga door met vraag $3 e$ \\
\hline$\square$ & stage & $\rightarrow$ & ga door met vraag $3 e$ \\
\hline 3 & geen werk of stage & $\rightarrow$ & ga door met vraag 13 \\
\hline$\square$ & Ioon & & $\rightarrow$ ga door met vraag 7 \\
\hline 2 & stagevergoeding of & kostenvergoe & ding $\rightarrow$ ga door met vraag 7 \\
\hline 3 & geen loon en ook ge & vergoeding & $\rightarrow$ ga door met vraag 7 \\
\hline
\end{tabular}


4. Wat doe je op dit moment?

Let op: maar één antwoord mogelijk! ik ben scholier

( 3 dagen of meer per week)

$\rightarrow$ ga door met vraag 5

2 ik heb betaald werk

(minstens 12 uur per week) $\rightarrow$ ga door met vraag 7

3 ik doe onbetaald werk

4 ik doe het huishouden

ik ben werkloos

5 ik vervul militaire/vervangende

dienst (geen KVV)

7 ik doe iets anders, namelijk: $\rightarrow$ ga door met vraag 6

$\rightarrow$ ga door met vraag 6

$\rightarrow$ ga door met vraag 6

$\rightarrow$ ga door met vraag 13

$\rightarrow$ ga door met vraag 6

\section{Huidige opleiding}

5 a. Welke opleiding volg je op dit moment? (bijv. KMBO, MTS, LTS, MEAO, MDGO)

b. Alleen voor $\angle B O$ en $M B O$ :

Welke vakrichting doe je binnen deze opleiding?

(bijv. bouw, winkelpraktijk, personeelswerk)

c. In welke gemeente volg je deze opleiding, en hoever is de school van je huis?

6. Bij vraag 4 heb je iets aangekruist. Vul hiernaast in of je ook nog betaald werk hebt. (minstens 12 uur per week)

$\rightarrow$ nee $\rightarrow \quad$ ga door met vraag 13

Je huidige werk en beroep

Heb je méér dan 1 baan, dan gelden de vragen 7 t/m 12 voor de baan waarin je de meeste uren werkt.

7 a. Is dit je eerste baan na het verlaten van de school? ja

b. Hoe ben je aan je huidige baan gekomen? Let op: maar één antwoord mogelijk!

c. Wanneer ben je in deze baan begonnen?

8 a. Betreft je huidige werk seizoenswerk of vakantiewerk?

b. In wat voor dienstverband werk je?
2 nee

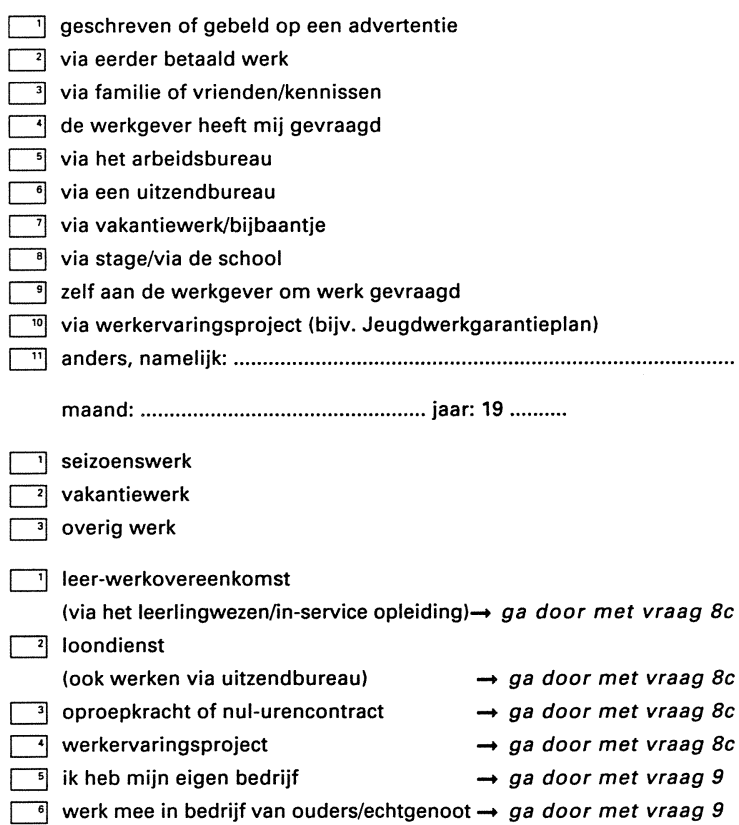


c. Wat voor aanstelling heb je?

9. Hoe heet het beroep of de functie die je hebt? (bijv. automonteur, metselaar, tuinder, receptioniste, verkoopster)

b. Wat zijn je voornaamste werkzaamheden? (bijv. verwarmingen installeren, schilderen, vee verzorgen, typen, kleding verkopen)

c. Op wat voor afdeling werk je? (bijv. administratie, montagehal, magazijn, receptie)

10a. Bij wat voor organisatie of bedrijf werk je? (bijv. machinefabriek, garagewerkplaats, kledingwinkel, ziekenhuis)

b. Hoeveel mensen werken er ongeveer? (het gaat om alle werknemers van het bedrijf in Nederland)

c. In welke plaats is het bedrijf gevestigd?

11 a. Welk soort opleiding werd voor je huidige baan vereist?

b. Werd ook nog een speciale vakrichting vereist? (bijv. de richting bouw of bedrijfsadministratie)

12a. Hoeveel uur per week werk je in deze baan (volgens je contract)?

- tel overwerk niet mee

- ga uit van de laatste maand

b. Hoeveel verdien je in deze baan ongeveer bruto per maand?

- eventuele toeslagen of fooien meerekenen - overwerk en vakantiegeld niet meetellen tijdelijk werk via een uitzendbureau

tijdelijk werk bij werkgever ( 1 jaar of korter)

tijdelijk werk bij werkgever (langer dan 1 jaar)

vaste baan of proeftijd voor een vaste baan

vaste

lagere school was genoeg

een lagere beroepsopleiding (bijv. LTS, LHNO)

3 MAVO

4 leerlingwezen

5 HAVONWO

6 een middelbare beroepsopleiding (bijv. MTS, MDGO)

7 een hogere beroepsopleiding (bijv. HTS, HEAO)

ja, de richting die ik zelf heb gevolgd

ja, maar een andere richting

nee

:...........u uur per week

(wanneer je in het leerlingwezen zit, tel dan de uren op school niet mee)

bruto ongeveer: gulden per maand (ga uit van de laatste maand, zie eventueel je loonstrookje)

\section{Op zoek naar (ander) werk \\ De vragen $13 \mathrm{t} / \mathrm{m} 24$ zijn voor iedereen bestemd}

13a. Ben je actief op zoek naar een (andere) baan? (een betaalde baan voor minstens 12 uur per week)

b. Zo ja, hoe heb je de afgelopen 4 weken naar werk gezocht?

Let op: meerdere antwoorden mogelijk! 
c. Sta je als werkzoekende ingeschreven bij het arbeidsbureau?

d. Stel, je vindt nú een (andere) geschikte baan. Hoe snel kun je dan beginnen?

e. Waarom kun je niet binnen 2 weken beginnen?
1 ja 2 nee

1 binnen 2 weken ga door met vraag 14 binnen 3 maanden $\rightarrow \quad g a$ door met vraag $13 e$ 3 pas na 3 maanden $\rightarrow$ ga door met vraag $13 e$

$\square$ vanwege opzegtermijn huidige baan

2 vanwege afronden van de huidige opleiding

3 vanwege afronden vrijwilligerswerk

vanwege regelen kinderopvang

vanwege vakantie of ziekte

vanwege een andere reden

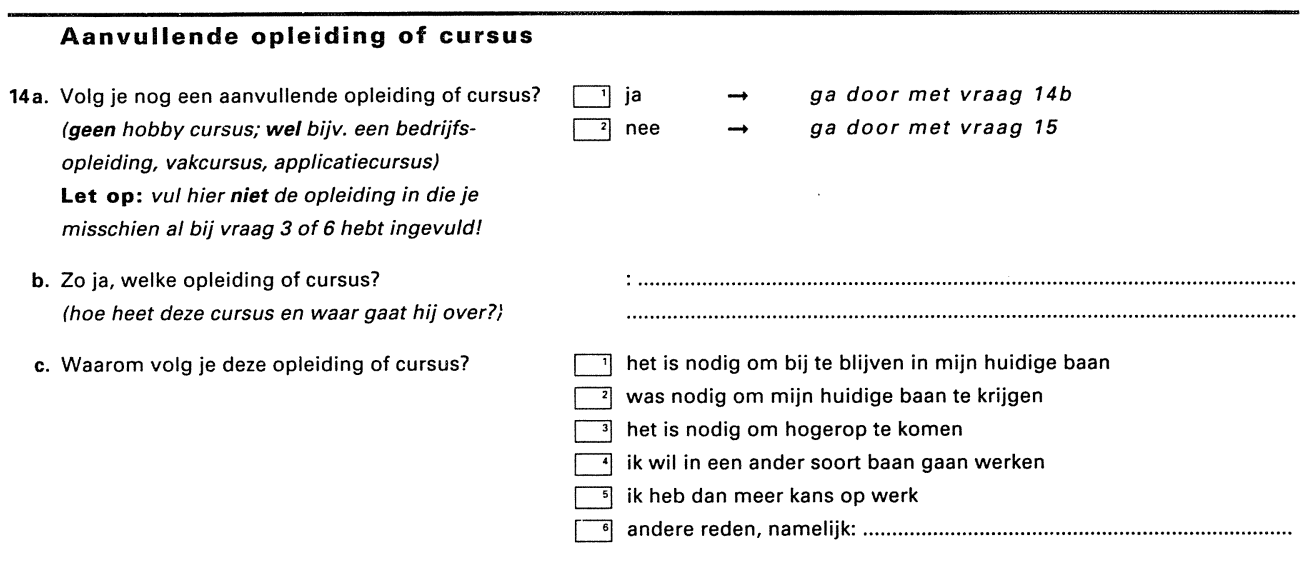

\section{De opleiding achteraf bezien}

15. Hoe vind je de aansluiting tussen je opleiding van vorig jaar en je huidige bezigheden? (bijv. je werk of opleiding)

$\begin{array}{ll}\square & \text { goed } \\ \square & \text { voldoende } \\ \square & \text { matig } \\ \square & \text { slecht }\end{array}$

16. Hieronder noemen we een aantal zaken.

Moet daar in de opleiding die je vorig jaar verlaten hebt méér of juist minder aandacht aan worden besteed?

a. Vakkennis/vaktheorie

b. Leren studeren

c. Vreemde talen (Engels, Duits e.d.)

d. Met cijfers werken (wiskunde, rekenen)

e. Informatica, automatisering

f. Praktijkoriëntatie of stage

g. Omgaan met apparatuur en materialen

h. Weten hoe een bedrijf georganiseerd is

i. Kennis van arbeidsvoorwaarden

(CAO, wat te doen bij ontslag e.d.)

j. Organiseren/plannen

k. Zelfstandig werken

I. Commerciële kennis, verkooptechniek

$\mathrm{m}$. Correcte spelling/foutloos schrijven

n. Een verslag of rapport schrijven

o. Spreekvaardigheid

p. Samenwerken met collega's

q. Met mensen/klanten omgaan

r. Beroepskeuze/studiekeuze

s. Leren solliciteren 
17. Als je opnieuw voor de keuze stond, zou je deze $\square$ ja opleiding dan opnieuw kiezen?

\section{Tot slot}

18. Wanneer ben je geboren?

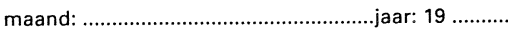

19. Geslacht

20. Tot welke bevolkingsgroep hoor je?

vrouw

7 Nederlandse

2 Surinaamse

3 Antilliaanse/Arubaanse

T Turkse

5 Marokkaanse

[6] Anders, namelijk:

21. Postcode huisadres (alléén de cijfers)

22. Wat is de hoogste opleiding van je ouders (of verzorgers)?

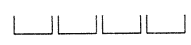

vader/verzorger

(1) lagere school

2 lagere beroepsopleiding

3 MAVO/MULO

4 HAVO/MMS

VWO/Gymnasium/HBS

6 middelbare beroepsopleiding

7 hogere beroepsopleiding

8 universiteit

9 weet ik echt niet

$\mathrm{ja}$, ik vind het goe

nee, ik heb hier bezwaar tegen

zijn gaan doen. Zo kan de school de leerlingen in

de toekomst beter voorbereiden op een

vervolgopleiding of een latere baan.

Vind je het goed wanneer aan je vroegere school

wordt doorgegeven wat je nu doet?

24. Wanneer heb je deze vragenlijst ingevuld? maand : 1993

\section{Opmerkingen}

Ruimte voor opmerkingen over de school, het werk, de vragenlijst, e.d.

Hartelijk bedankt yoor het invullen.

Stuur de vragenlijst zo snel mogelijk op in de antwoordenvelop (een postzegel is niet nodig). 


\section{Bijlage 5 Definitie van de term 'schoolverlater'}

Een schoolverlater is een leerling die gedurende het schooljaar 1993/94 de school (gediplomeerd of voortijdig) heeft verlaten. Dit betekent dat een leerling die is gezakt voor het eindexamen en het laatste jaar over doet buiten het onderzoek valt.

Een gediplomeerde schoolverlater is een scholier die met goed gevolg het eindexamen heeft afgelegd van de IVBO-opleiding die hij/zij in het schooljaar 1993/94 volgde. Degenen die in het schooljaar 1993/94 in de kopklas hebben gezeten (niveauverdiepers/profielverbeteraars), zijn gediplomeerde schoolverlater.

Een voortijdig schoolverlater is een scholier die gedurende het schooljaar 1993/94 de school zonder diploma heeft verlaten. Daarbij worden de voortijdige schoolverlaters uit het eerste en tweede schooljaar niet meegenomen in het onderzoek. 

Bijlage 6 Schoolformulier proefmeting bestemming IVBO'ers 

SCHOOLFORMULIER PROEFONDERZOEK BESTEMMING IVBO'ERS

Omcirkel a.u.b. wat van toepassing is of vul het antwoord op de stippellijntjes in!

ADMINISTRATIEVE ONDERZOEKSGEGEVENS

Schoolnummer

: $\cdots \cdots \cdots$

Volgnummer schoolverlater

: $\ldots \ldots \ldots$

Wijze van enquêtering

telefonisch door school

telefonisch door ROA

schriftelijk door ROA

\section{PERSONALIA}

Naam + voorletters

Adres

Postcode + woonplaats

Telefoonnummer

Geboor tedatum (dag/maand/jaar)

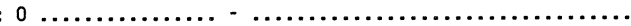

:............... .19 .........

Geslacht

Nationaliteit

Nederlandse

andere, $\mathrm{nl}$ :

VOOROPLEIDING

Vooropleiding

\section{Basisschool}

LOM

VSO-LOM

VSO-MLK

VSO-ZMLK

VSO-ZMOK

(I) $\mathrm{VBO}$

buitenlandse opleiding

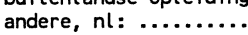

Van vooropleiding diploma behaald?

ja

niet van toepassing

GEVOLGDE IVBO-OPLEIDING

Techniek

AVMB dienstverlening

bouwtechniek

consumptieve techniek

differentiatie fijnhout / meubelmaken en -stofferen

electrotechniek

instal latietechniek

installatietechniek

motorvoertuigentechni k

motorvoertuigek

procestechniek
schilderen/afwerkingstechni eken/reclametekenen

overig techniek 
Economisch-administratief

Verzorgend

Agrarisch

Wanneer met deze opleiding begonnen*

En in welke klas?

Wanneer deze opleiding verlaten*

En in welke $\mathrm{klas}$ ?

Van deze opleiding diploma behaald?

Aantal gevolgde vakken kantoorpraktijk

lager middenstandsonderwijs

vrije afstudeerrichting economisch-administratief winkelprakt $i j k$

overig economisch-administratief

kantoor- en verkoopprakt i jk

textielverwerkende beroepen, theorie

textielverwerkende beroepen, praktijk

ui terlijke verzorging

vrije afstudeerrichting verzorgend onderwijs

overig verzorgend

\section{groenopleidingen}

bloemopleidingen

plantopleidingen

begin : maand:

jaar: 19:

klas $: \ldots . . . .$.

einde: maand:

jaar: 19:

$\mathrm{klas}:$

$\begin{array}{ll}1 & \text { ja } \\ 2 & \text { nee }\end{array}$

op A-niveau: $\ldots \ldots \ldots .$.

op B-niveau:

op C-niveau:

op D-niveau:

* Aan deze school!

BESTEMMING NA DE IVBO-OPLEIDING

1. Wat is de leerling na het verlaten van de IVBO-opleiding gaan doen?

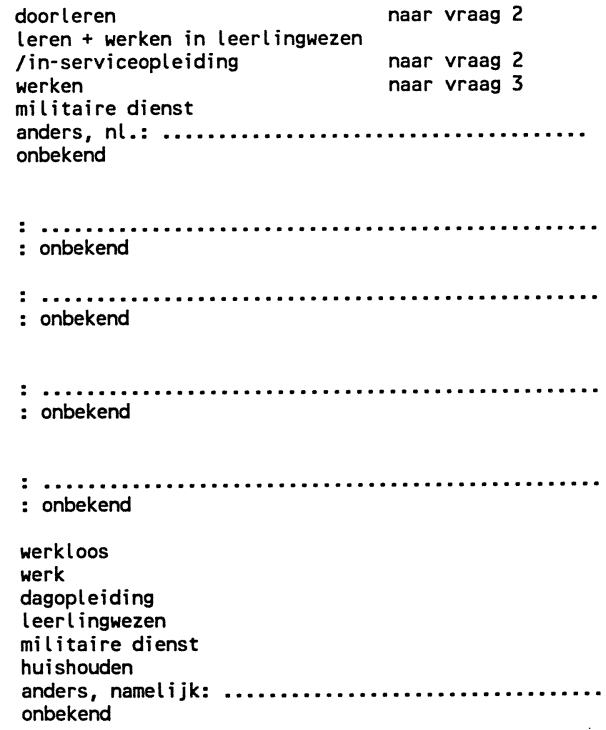

2. School type vervolgopleiding (indien $v$ toepassing: opleidingsrichting vervolgopleiding

3. Bij wat voor organisatie of bedrijf is de leerling gaan werken? (bv. mach inefabriek, kledingwinkel)

Welk beroep is de leerling gaan uitoefenen? (bv. Lasser, tuinder, ober)

1
2
3
4
5
6

telsel)
is

4. Wat doet de leerling op dit moment? 
Bijlage 7 Vragenlijst schriftelijke proefmeting bestemming IVBO'ers 

VRAGENLIJST SCHOOLVERLATERS IVBO

Beste oud-leerling,

Vorig jaar heb je de IVBO-opleiding verlaten.

Jouw school wil graag weten wat je na deze opleiding bent gaan doen.

Daarom vragen wij je deze vragenlijst in te vullen.

Het is belangrijk dat je de vragenlijst invult. Ook als je van deze opleiding géén diploma hebt behaald.

De ingevulde vragenlijst kun je zonder postzegel in de antwoordenvelop opsturen naar het ROA.

Wij hopen dat je de vragenlijst zo spoedig mogelijk invult en opstuurt.

Alvast bedankt!

Toelichting voor het invullen

Lees eerst de gehele vraag.

Omcirkel daarna het antwoord of vul je antwoord op de stippellijntjes in.

Je mag bij iedere vraag maar één antwoord omcirkelen.

\section{OPLEIDING VORIG SCHOOLJAAR (1993/1994)}

1. Heb je vorig schooljaar de opleiding gevolgd?

1 ja

2 nee, ik heb een andere opleiding gevolgd,

namelijk:

NA DE OPLEIDING (VAN SCHOOLJAAR 1993/1994)

2a. Ben je na de opleiding werkloos geweest?

$\begin{array}{ll}1 & \text { ja } \\ 2 & \text { nee }\end{array}$

b. Zo ja, hoeveel maanden ben je in totaal werkloos geweest na de opleiding?

maanden werkloos na de opleiding

\section{HUIDIGE BEZIGHEDEN}

3a. Heb je op dit moment betaald werk?

1 ja

2 nee

b. Zo ja, hoeveel uur per week werk je? (het gaat om betaald werk)

: ............... uur per week

c. Zo nee, zou je een baan van minstens 12 uur per week willen hebben?

ja 
4a. Ben je op dit moment scholier?

$1 \quad$ ja

b. Zo ja, welke opleiding volg je nu?

naam opleiding:

(bijv. KMBO, MTS, MDGO, MAS)

c. Welke vakrichting volg je binnen deze opleiding?

naam richting:

(bijv. bouwkunde, verzorging, tuinbouw)

5a. Zit je in het leerlingwezen? (bijv. VOLTT, SOM, SVK, OVD)

$\begin{array}{ll}1 & \text { ja } \\ 2 & \text { nee }\end{array}$

b. Zo ja, welke opleiding volg je in het leerlingwezen?

naam opleiding

(bijv. voor automonteur, lasser)

6. Zit je op dit moment in militaire dienst?

$\begin{array}{ll}1 & \text { ja } \\ 2 & \text { nee }\end{array}$

HUIDIG WERK

$>>$ De volgende vragen $(7 \mathrm{t} / \mathrm{m} 10)$ hoef je alleen in te vullen als je op dit moment een baan hebt! $<<<$

7. Wat voor baan heb je? (maar één antwoord mogelijk!)

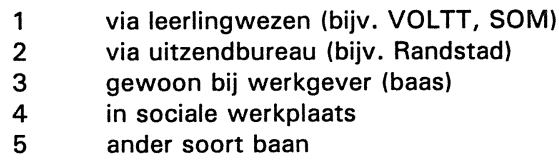

8a. Wat is je beroep?

(bijv. lasser, verkoper, automonteur, metselaar, ober, gezinshulp)

b. Wat zijn je voornaamste werkzaamheden?

(bijv. verkopen van kleding, schilderen, achter de kassa zitten) 
9. Bij wat voor bedrijf werk je?

(bijv. machinefabriek, garage, kledingwinkel, hotel)

10. Hoe past het werk dat je nu doet bij je vroegere opleiding?

$$
\begin{array}{ll}
1 & \text { goed } \\
2 & \text { gaat wel } \\
3 & \text { slecht }
\end{array}
$$

$>>$ De volgende vragen $(11 \mathrm{t} / \mathrm{m} 17)$ zijn voor iedereen bedoeld!

\section{OP ZOEK NAAR WERK}

11. Heb je de afgelopen tijd naar werk gezocht?
1 ja, de afgelopen vier weken
2 ja, het afgelopen half jaar
3 nee

12. Stel, je vindt nú een baan. Hoe snel kun je daarmee dan beginnen?

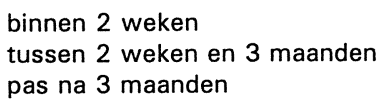

13. Sta je ingeschreven bij het Arbeidsbureau?

1 ja

2 nee

14. Mogen jóuw antwoorden aan je vroegere school worden doorgegeven?

1 ja, ik vind dit goed

2 nee, ik wil dit niet 


\section{TOT SLOT}

Wij zijn benieuwd wat je van deze vragenlijst vond.

Daarom vragen wij je om ook de volgende antwoorden in te vullen.

15. Hoe lang heb je er over gedaan om de vragenlijst in te vullen?

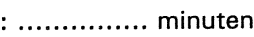

16a. Waren er moeilijke vragen bij?

$1 \quad$ ja

b. Zo ja, welke vragen vond je moeilijk?

vraag nummer:

c. Waarom vond je deze vragen moeilijk?

17. Heb je hulp van anderen nodig gehad om de vragenlijst in te vullen?

1 ja

nee

\section{BEDANKT VOOR HET INVULLEN}

Stuur de vragenlijst zo snel mogelijk op in de antwoordenvelop (een postzegel is niet nodig). 
Bijlage 8 Vragenlijst telefonische proefmeting bestemming IVBO'ers 



\section{VRAGENLIJST TELEFONISCH PROEFONDERZOEK IVBO’ERS}

Administratieve onderzoeksgegevens

Schoolnummer $\quad:$............... (zie Schoolformulier)

Volgnummer leerling

(zie Schoolformulier)

\begin{tabular}{|c|c|c|c|}
\hline 1. Resultaat telefonische benadering & $\begin{array}{l}1 \\
2\end{array}$ & $\begin{array}{l}\text { geslaagd } \\
\text { niet geslaagd }\end{array}$ & $\begin{array}{l}->\text { ga naar } 2 \\
->\text { ga naar } 3\end{array}$ \\
\hline 2. Gesproken met: & $\begin{array}{l}1 \\
2\end{array}$ & \multicolumn{2}{|c|}{$\begin{array}{l}\text { ouders/verzorgers } \\
\text { oud-leerling }\end{array}$} \\
\hline $\begin{array}{l}\text { 3. Reden niet-slagen } \\
\text { telefonische benadering }\end{array}$ & $\begin{array}{l}1 \\
2 \\
3 \\
4 \\
5 \\
6 \\
7\end{array}$ & \multicolumn{2}{|c|}{$\begin{array}{l}\text { heeft geen telefoon } \\
\text { heeft geheim telefoonnr. } \\
\text { telefoon afgesloten } \\
\text { telefoonnr. klopte niet } \\
\text { na herhaald bellen onbereikbaar } \\
\text { weigert medewerking } \\
\text { andere reden, nl....................... }\end{array}$} \\
\hline
\end{tabular}

Toelichting voor het invullen

S.v.p. het antwoord omcirkelen of op de stippellijntjes invullen.

Bij iedere vraag mag maar één antwoord worden omcirkeld.

OPLEIDING VORIG SCHOOLJAAR (1993/1994)

1. Heb je vorig schooljaar de opleiding

gevolgd? (zie Schoolformulier)

$1 \quad$ ja

2 nee, ik heb een andere opleiding gevolgd,

namelijk:

NA DE OPLEIDING (VAN SCHOOLJAAR 1993/1994)

2a. Ben je na de opleiding werkloos geweest?

$1 \quad$ ja

b. Zo ja, hoeveel maanden ben je in totaal werkloos geweest na de opleiding?

maanden werkloos na de opleiding

\section{HUIDIGE BEZIGHEDEN}

3a. Heb je op dit moment betaald werk?

$\begin{array}{ll}1 & \text { ja } \\ 2 & \text { nee }\end{array}$

b. Zo ja, hoeveel uur per week werk je? (het gaat om betaald werk)

uur per week 
c. Zo nee, zou je een baan van minstens 12 uur per week willen hebben?

$\begin{array}{ll}1 & \text { ja } \\ 2 & \text { nee }\end{array}$

4a. Ben je op dit moment scholier?

$1 \quad$ ja

2 nee

b. Zo ja, welke opleiding volg je nu?

naam opleiding:

(bijv. KMBO, MTS, MDGO, MAS)

c. Welke vakrichting volg je binnen deze opleiding?

naam richting:

(bijv, bouwkunde, verzorging, tuinbouw)

5a. Zit je in het leerlingwezen? (bijv. VOLTT, SOM, SVK, OVD)

1 ja

b. Zo ja, welke opleiding volg je in het leerlingwezen?

naam opleiding:

(bijv. voor automonteur, lasser)

6. Zit je op dit moment in militaire dienst?

$1 \quad$ ja

2 nee

HUIDIG WERK

$>>$ De volgende vragen $(7 \mathrm{t} / \mathrm{m} \mathrm{10}$ ) alleen invullen als oud-leerling op dit moment een baan heeft

7. Wat voor baan heb je? (maar één antwoord mogelijk!)

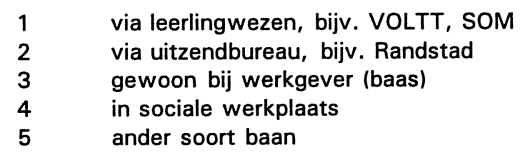

8a. Wat is je beroep?

(bijv. lasser, verkoper, automonteur, metselaar, ober, gezinshulp)

b. Wat zijn je voornaamste werkzaamheden?

(bijv. verkopen van kleding, schilderen, achter de kassa zitten) 
9. Bij wat voor bedrijf werk je?

(bijv. machinefabriek, garage, kledingwinkel, hotel)

10. Hoe past het werk dat je nu doet bij je vroegere opleiding?

$$
\begin{array}{ll}
1 & \text { goed } \\
2 & \text { gaat wel } \\
3 & \text { slecht }
\end{array}
$$

$>>$ De volgende vragen $(11 \mathrm{t} / \mathrm{m} \mathrm{13})$ zijn weer voor iedereen bestemd!

\section{OP ZOEK NAAR WERK}

11. Heb je de afgelopen tijd naar werk gezocht?

$\begin{array}{ll}1 & \text { ja, de afgelopen vier weken } \\ 2 & \text { ja, het afgelopen half jaar } \\ 3 & \text { nee }\end{array}$

12. Stel, je vindt nú een baan. Hoe snel kun je daarmee dan beginnen?

$\begin{array}{ll}1 & \text { binnen } 2 \text { weken } \\ 2 & \text { tussen } 2 \text { weken en } 3 \text { maanden } \\ 3 & \text { pas na } 3 \text { maanden }\end{array}$

13. Sta je ingeschreven bij het Arbeidsbureau?

1 ja

Hartelijk dank voor de medewerking!

\section{EVALUATIE-VRAGEN}

* Hoe lang duurde het gesprek?

minuten

* Met welke vragen had de respondent moeite?

vraag:

* Hoe verliep het gesprek?

erg makkelijk/spontaan

ging wel

moeizaam 



\section{SCHOOLFORMULIER PROEFONDERZOEK BESTEMIMING IVBO'ERS}

Omcirkel a.u.b. wat van toepassing is of vul het antwoord op de stippellijntjes in!

\section{ADMINISTRATIEVE ONDERZOEKSGEGEVENS}

School nummer

Volgnummer schoolverlater

Wijze van enquêtering

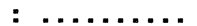

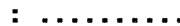

telefonisch door school

telefonisch door ROA

schriftelijk door ROA

\section{PERSONALIA}

$\mathrm{Naam}+$ voorletters

Adres

Postcode + woonplaats

Telefoonnummer

Geboortedatum (dag/maand/jaar)

$: 0$

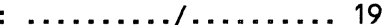

Geslacht

$1 \quad \operatorname{man}$

2 vrouw

National iteit

Neder l andse

2 andere, $\mathrm{nl}$ :

\section{VOOROPLEIDING}

Vooropleiding

\begin{tabular}{|c|c|}
\hline 1 & Basisschool \\
\hline 2 & LOM \\
\hline 3 & VSO-LOM \\
\hline 4 & VSO-MLK \\
\hline 5 & VSO-ZMLK \\
\hline 6 & VSO-ZMOK \\
\hline 7 & (I) VBO \\
\hline 8 & buitenlandse opleiding \\
\hline 9 & andere, $\mathrm{nl}: \ldots \ldots \ldots$. \\
\hline
\end{tabular}

Van vooropleiding diploma behaald?

ja

nee

niet van toepassing

GEVOLGDE IVBO-OPLEIDING

Techniek

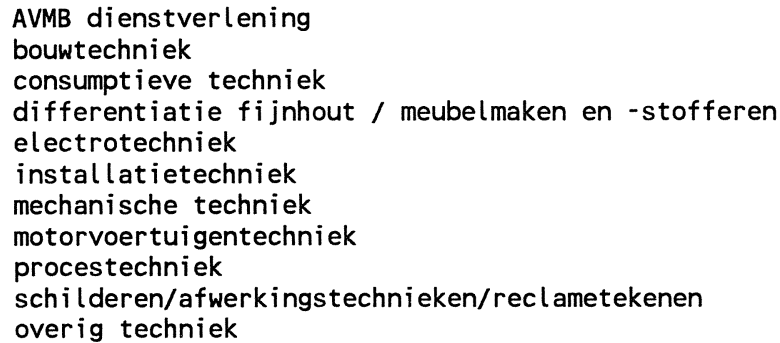


lager middenstandsonderwi js

vrije afstudeerrichting economisch-administratief winkelpraktijk

overig economisch-administratief

Verzorgend

kantoor - en verkooppraktijk

textielverwerkende beroepen, theorie

textielverwerkende beroepen, praktijk

uiterlijke verzorging

verzorgende beroepen

vrije afstudeerrichting verzorgend onderwijs

overig verzorgend

Agrarisch

groenopleidingen

bloemopleidingen

plantopleidingen

dieropleidingen

Wanneer met deze opleiding begonnen*

En in welke klas?

Wanneer deze opleiding verlaten*

En in welke klas?

Van deze opleiding diploma behaald?

Aantal gevolgde vakken begin : maand:

jaar: 19:

klas $: \ldots \ldots \ldots$

einde: maand: jaar: 19:

$\mathrm{klas}$

$\begin{array}{ll}1 & \text { ja } \\ 2 & \text { nee }\end{array}$

op A-niveau:

op B-niveau:

op C-niveau:

op D-niveau:

* Aan deze school!

\section{BESTEMMING NA DE IVBO-OPLEIDING}

1. Wat is de leerling na het verlaten van de IVBO-opleiding gaan doen?

2. Schooltype vervolgopleiding (indien $v$ toepassing: naam leerlingstelsel)

Opleidingsrichting vervolgopleiding

3. Bij wat voor organisatie of bedrijf is de leerling gaan werken?

(bv. machinefabriek, kledingwinkel)

Welk beroep is de leerling gaan uitoefenen? (bv. Lasser, tuinder, ober)

4. Wat doet de leerling op dit moment? doorleren

leren + werken in leerlingwezen

in-serviceopleiding

werken

militaire dienst

anders, $\mathrm{nl}$.

onbekend naar vraag 2

naar vraag 2 naar vraag 3

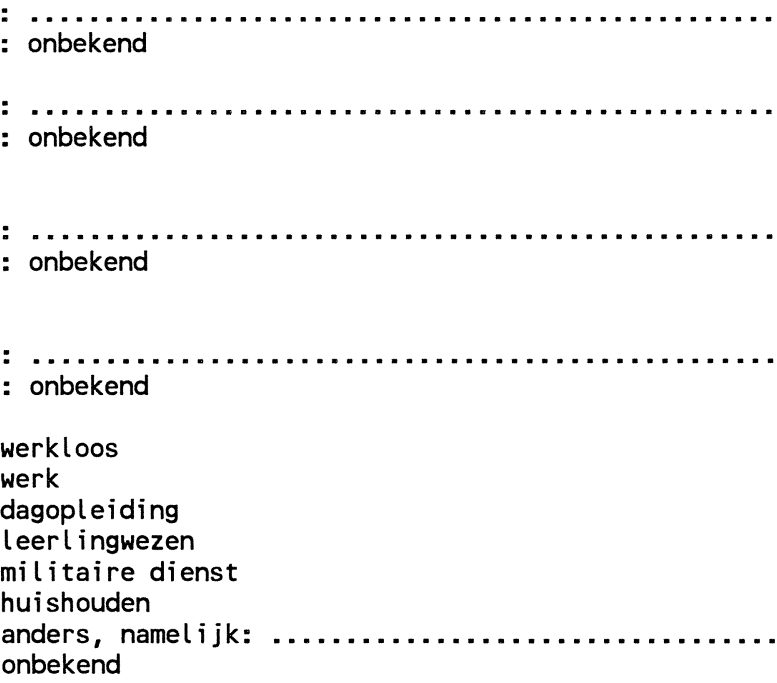


Beste oud-leerling,

Vorig jaar heb je de IVBO-opleiding verlaten.

Jouw school wil graag weten wat je na deze opleiding bent gaan doen.

Daarom vragen wij je deze vragenlijst in te vullen.

Het is belangrijk dat je de vragenlijst invult. Ook als je van deze opleiding géén diploma hebt behaald.

De ingevulde vragenlijst kun je zonder postzegel in de antwoordenvelop opsturen naar het ROA.

Wij hopen dat je de vragenlijst zo spoedig mogelijk invult en opstuurt.

\section{Alvast bedankt!}

\section{Toelichting voor het invullen}

Lees eerst de gehele vraag.

Omcirkel daarna het antwoord of vul je antwoord op de stippellijntjes in.

Je mag bij iedere vraag maar één antwoord omcirkelen.

\section{OPLEIDING VORIG SCHOOLJAAR (1993/1994)}

1. Heb je vorig schooljaar de opleiding gevolgd?

1 ja

2 nee, ik heb een andere opleiding gevolgd,

namelijk:

\section{NA DE OPLEIDING (VAN SCHOOLJAAR 1993/1994)}

2a. Ben je na de opleiding werkloos geweest?

$\begin{array}{ll}1 & \text { ja } \\ 2 & \text { nee }\end{array}$

b. Zo ja, hoeveel maanden ben je in totaal werkloos geweest na de opleiding? maanden werkloos na de opleiding

\section{HUIDIGE BEZIGHEDEN}

3a. Heb je op dit moment betaald werk?

$\begin{array}{ll}1 & \text { ja } \\ 2 & \text { nee }\end{array}$

b. Zo ja, hoeveel uur per week werk je? (het gaat om betaald werk)

$$
\text { : .............uur per week }
$$

c. Zo nee, zou je een baan van minstens 12 uur per week willen hebben?

$$
\begin{array}{ll}
1 & \text { ja } \\
2 & \text { nee }
\end{array}
$$


4a. Ben je op dit moment scholier?

$\begin{array}{ll}1 & \text { ja } \\ 2 & \text { nee }\end{array}$

b. Zo ja, welke opleiding volg je nu?

naam opleiding:

(bijv. KMBO, MTS, MDGO, MAS)

c. Welke vakrichting volg je binnen deze opleiding?

naam richting:

(bijv. bouwkunde, verzorging, tuinbouw)

5a. Zit je in het leerlingwezen? (bijv. VOLTT, SOM, SVK, OVD)

$\begin{array}{ll}1 & \text { ja } \\ 2 & \text { nee }\end{array}$

b. Zo ja, welke opleiding volg je in het leerlingwezen?

naam opleiding:

(bijv. voor automonteur, lasser)

6. Zit je op dit moment in militaire dienst?

1 ja

2 nee

\section{HUIDIG WERK}

De volgende vragen $(7 \mathrm{t} / \mathrm{m} \mathrm{10)}$ hoef je alleen in te vullen als je op dit moment een baan hebt! $<<<$

7. Wat voor baan heb je? (maar één antwoord mogelijk!)

$\begin{array}{ll}1 & \text { via leerlingwezen (bijv. VOLTT, SOM) } \\ 2 & \text { via uitzendbureau (bijv. Randstad) } \\ 3 & \text { gewoon bij werkgever (baas) } \\ 4 & \text { in sociale werkplaats } \\ 5 & \text { ander soort baan }\end{array}$

8a. Wat is je beroep?

(bijv. lasser, verkoper, automonteur, metselaar, ober, gezinshulp)

b. Wat zijn je voornaamste werkzaamheden?

(bijv. verkopen van kleding, schilderen, achter de kassa zitten) 
9. Bij wat voor bedrijf werk je?

(bijv. machinefabriek, garage, kledingwinkel, hotel)

10. Hoe past het werk dat je nu doet bij je vroegere opleiding?

$\begin{array}{ll}1 & \text { goed } \\ 2 & \text { gaat wel } \\ 3 & \text { slecht }\end{array}$

De volgende vragen (11 t/m 17) zijn voor iedereen bedoeld!

OP ZOEK NAAR WERK

11. Heb je de afgelopen tijd naar werk gezocht?

$\begin{array}{ll}1 & \text { ja, de afgelopen vier weken } \\ 2 & \text { ja, het afgelopen half jaar } \\ 3 & \text { nee }\end{array}$

12. Stel, je vindt nú een baan. Hoe snel kun je daarmee dan beginnen?

$1 \quad$ binnen 2 weken
$2 \quad$ tussen 2 weken en 3 maanden
$3 \quad$ pas na 3 maanden

13. Sta je ingeschreven bij het Arbeidsbureau?

$\begin{array}{ll}1 & \text { ja } \\ 2 & \text { nee }\end{array}$

14. Mogen jóuw antwoorden aan je vroegere school worden doorgegeven?

$1 \quad$ ja, ik vind dit goed

2 nee, ik wil dit niet 


\section{TOT SLOT}

Wij zijn benieuwd wat je van deze vragenlijst vond.

Daarom vragen wij je om ook de volgende antwoorden in te vullen.

15. Hoe lang heb je er over gedaan om de vragenlijst in te vullen? minuten

16a. Waren er moeilijke vragen bij?

$\begin{array}{ll}1 & \text { ja } \\ 2 & \text { nee }\end{array}$

b. Zo ja, welke vragen vond je moeilijk?

vraag nummer:

c. Waarom vond je deze vragen moeilijk?

17. Heb je hulp van anderen nodig gehad om de vragenlijst in te vullen?

$\begin{array}{ll}1 & \text { ja } \\ 2 & \text { nee }\end{array}$

\section{BEDANKT VOOR HET INVULLEN!}

Stuur de vragenlijst zo snel mogelijk op in de antwoordenvelop (een postzegel is niet nodig). 


\section{VRAGENLIJST TELEFONISCH PROEFONDERZOEK IVBO'ERS}

Administratieve onderzoeksgegevens

Schoolnummer

Volgnummer leerling

1. Resultaat telefonische benadering

2. Gesproken met:

3. Reden niet-slagen telefonische benadering (zie Schoolformulier)

(zie Schoolformulier)

\section{Toelichting voor het invullen}

S.v.p. het antwoord omcirkelen of op de stippellijntjes invullen.

Bij iedere vraag mag maar één antwoord worden omcirkeld.

\section{OPLEIDING VORIG SCHOOLJAAR (1993/1994)}

1. Heb je vorig schooljaar de opleiding

$1 \quad$ ja

2 nee, ik heb een andere opleiding gevolgd,

namelijk:

\section{NA DE OPLEIDING (VAN SCHOOLJAAR 1993/1994)}

2a. Ben je na de opleiding werkloos geweest?

$$
\begin{array}{ll}
1 & \text { ja } \\
2 & \text { nee }
\end{array}
$$

b. Zo ja, hoeveel maanden ben je in totaal werkloos geweest na de opleiding?

$$
\text { maanden werkloos na de opleiding }
$$

\section{HUIDIGE BEZIGHEDEN}

3a. Heb je op dit moment betaald werk?

$$
\begin{array}{ll}
1 & \text { ja } \\
2 & \text { nee }
\end{array}
$$

b. Zo ja, hoeveel uur per week werk je? (het gaat om betaald werk) 
c. Zo nee, zou je een baan van minstens 12 uur per week willen hebben?

$1 \quad$ ja

4a. Ben je op dit moment scholier?

$\begin{array}{ll}1 & \text { ja } \\ 2 & \text { nee }\end{array}$

b. Zo ja, welke opleiding volg je nu?

naam opleiding:

(bijv. KMBO, MTS, MDGO, MAS)

c. Welke vakrichting volg je binnen deze opleiding?

naam richting:

(bijv. bouwkunde, verzorging, tuinbouw)

5a. Zit je in het leerlingwezen? (bijv. VOLTT, SOM, SVK, OVD)

$\begin{array}{ll}1 & \text { ja } \\ 2 & \text { nee }\end{array}$

b. Zo ja, welke opleiding volg je in het leerlingwezen?

naam opleiding:

(bijv. voor automonteur, lasser)

6. Zit je op dit moment in militaire dienst?

$1 \quad$ ja

2 nee

\section{HUIDIG WERK}

De volgende vragen (7 t/m 10) alleen invullen als oud-leerling op dit moment een baan heeft! $\quad<<<$

7. Wat voor baan heb je? (maar één antwoord mogelijk!)

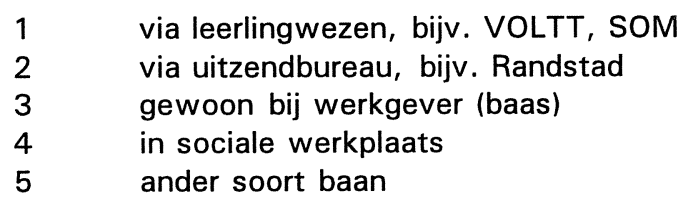

8a. Wat is je beroep?

(bijv. lasser, verkoper, automonteur, metselaar, ober, gezinshulp)

b. Wat zijn je voornaamste werkzaamheden?

(bijv. verkopen van kleding, schilderen, achter de kassa zitten) 
9. Bij wat voor bedrijf werk je?

(bijv. machinefabriek, garage, kledingwinkel, hotel)

10. Hoe past het werk dat je nu doet bij je vroegere opleiding?

$\begin{array}{ll}1 & \text { goed } \\ 2 & \text { gaat wel } \\ 3 & \text { slecht }\end{array}$

De volgende vragen $(11 \mathrm{t} / \mathrm{m} \mathrm{13}$ ) zijn weer voor iedereen bestemd!

\section{OP ZOEK NAAR WERK}

11. Heb je de afgelopen tijd naar werk gezocht?
1 ja, de afgelopen vier weken
2 ja, het afgelopen half jaar
3 nee

12. Stel, je vindt nú een baan. Hoe snel kun je daarmee dan beginnen?
1 binnen 2 weken
2 tussen 2 weken en 3 maanden
3 pas na 3 maanden

13. Sta je ingeschreven bij het Arbeidsbureau?
$1 \quad$ ja
2 nee

Hartelijk dank voor de medewerking!

\section{EVALUATIE-VRAGEN}

Hoe lang duurde het gesprek?

minuten

Met welke vragen had de respondent moeite?

vraag:

Hoe verliep het gesprek?

1 erg makkelijk/spontaan

2 ging wel

3 moeizaam 
Beste oud-leerling,

Vorig jaar heb je de schoolopleiding afgesloten. Op basis van onze gegevens gaat het hierbij om de opleiding die hieronder afgedrukt staat. De school is zeer geïnteresseerd in de ervaringen die je daarna hebt opgedaan.

Ben je na het verlaten van de school gaan werken, of ben je een andere opleiding gaan volgen? Om op deze en andere vragen een antwoord te krijgen, willen we je vragen deze vragenlijst in te vullen.

De school werkt, evenals een groot aantal andere scholen in Nederland, in het kader van het project "Registratie van Uitstroom en Bestemming van Schoolverlaters" nauw samen met het regionale Adviescentrum voor Opleiding en Beroep en het Servicebureau Schoolverlatersinformatie.

Wanneer je deze vragenlijst invult draag je ertoe bij dat we beter zicht krijgen op de aansluiting van de opleiding op een vervolgopleiding of op een baan. De opleiding kan dan beter worden afgestemd op vervolgonderwijs of werk. De uitkomsten zijn ook heel belangrijk voor jongeren die nog een keuze moeten maken voor een bepaalde opleiding. Zij kunnen dan zien wat er mogelijk is na verschillende opleidingen. Het invullen van de vragenlijst kost je beslist niet veel tijd!

De ingevulde vragenlijst kun je zonder postzegel in de bijgevoegde antwoordenveloppe opsturen naar het Servicebureau Schoolverlatersinformatie. De formulieren komen dus niet meer terug op school.

De gegevens worden anoniem verwerkt. Dat wil zeggen, alle antwoorden worden opgeteld en niemand weet straks wat "jij" hebt ingevuld. Jouw eigen gegevens worden alleen aan de school doorgegeven wanneer je daar geen bezwaar tegen hebt. Dit kun je aangeven bij vraag 23. en opsturen.

Wij hopen dat je mee wilt werken en de vragenlijst zo spoedig mogelijk wilt invullen

Bedankt voor je medewerking!

Vul je antwoord op de stippellijntjes in of kruis een hokje aan. Het kan zijn dat je een aantal vragen niet hoeft in te vullen. Let daarom goed op naar welke vraag je wordt doorgestuurd. Bij de meeste vragen mag je maar één antwoord geven. Als je meer antwoorden mag invullen, hebben wij dit bij de vraag gezet.

\section{Opleiding vorig jaar (schoollaar 1991/1992)}

1 a. Hiernaast staat de dagopleiding die je vorig schooljaar (1991/1992) gevolgd hebt. Klopt dit?

\section{ja}

nee, ik heb een andere dagopleiding gevolgd, namelijk:

b. Wanneer ben je met deze opleiding begonnen? En in welke klas of leerjaar?

c. Wanneer heb je deze opleiding verlaten? En in welke klas of leerjaar? maand : jaar: 19

klas/leerjaar:

maand : jaar: 19

klas/leerjaar: 
d nee

$\rightarrow$ ga door met vraag $1 \mathrm{~h}$

e. Heb je na het diploma nog een vijfde leerjaar of $\square$ ja kopklas gedaan?

nee

f. Hoeveel vakken heb je gedaan?

En op welk niveau?

g. Heb je na het diploma nog een aanvullend certificaat gehaald? (bijv. lassen)

h. Waarom heb je deze opleiding niet afgemaakt?

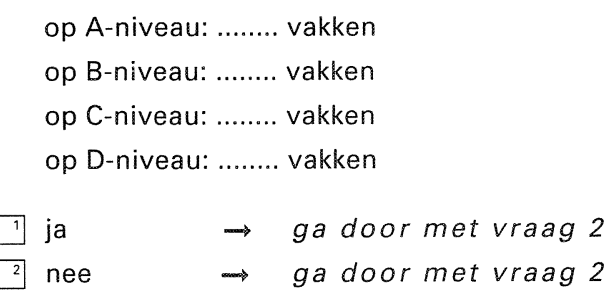

om persoonlijke redenen (verhuisd, ziekte, e.d.)

vanwege de school (slechte begeleiding, problemen met de leerkrachten, e.d.)

3 vanwege de opleiding (sloot niet aan, te zwaar, e.d.)

omdat ik liever wilde werken

vanwege een andere reden, namelijk:

\section{Na de opleiding}

2 a. Wat wilde je vorig jaar direct na de opleiding gaan doen?

b. Wanneer ben je actief begonnen met werk zoeken? (je kunt ook al begonnen zijn met zoeken voordat je de opleiding verlaten hebt)

c. Hoeveel maanden ben je in totaal werkloos geweest sinds je de opleiding verlaten hebt?

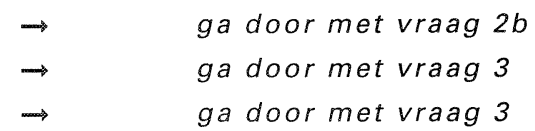
.. jaar: 19 ...........

( $v u l$ ' $O$ ' maanden in wanneer je niet werkloos bent geweest)

\section{Huidige bezigheden}

3 a. Volg je op dit moment een opleiding in:

- het leerlingstelsel (bijv. SOM, VEV, INNOVAM) of

- een in-service opleiding in de verpleging of

verzorging (bijv. A-verpleging of

ziekenverzorging)?

b. Welke opleiding in het leerlingstelsel/in-service volg je op dit moment?

(bijv. voor automonteur, installateur, ziekenverzorgende, A-verpleegkundige)

c. Alléén voor personen in het leerlingwezen: Hoe heet het leerlingstelsel? (bijv. ECABO, INNOVAM, SOM, VEV, OVDB)

d. Heb je naast de opleiding op school ook werk of een stage?

e. Krijg je voor dit werk of de stage loon of alleen maar een onkostenvergoeding?

maand :

$\begin{array}{lll}\text { werken } & \rightarrow & \text { ga door met vraag } 2 b \\ 2 \text { verder leren } & \rightarrow & \text { ga door met vraag } 3 \\ 3 \text { iets anders } & \rightarrow & \text { ga door met vraag } 3\end{array}$

(n)


4. Wat doe je op dit moment?

Let op: maar één antwoord mogelijk! ik ben scholier

(3 dagen of meer per week)

$\rightarrow$ ga door met vraag 5

2 ik heb betaald werk

(minstens 12 uur per week)

$\rightarrow$ ga door met vraag 7

$\rightarrow$ ga door met vraag 6

$\rightarrow$ ga door met vraag 6

$\rightarrow$ ga door met vraag 6

$\rightarrow$ ga door met vraag 13

\section{Huidige opleiding}

5 a. Welke opleiding volg je op dit moment? (bijv. KMBO, MTS, LTS, MEAO, MDGO)

b. Alleen voor $\angle B O$ en $M B O$ :

Welke vakrichting doe je binnen deze opleiding?

(bijv. bouw, winkelpraktijk, personeelswerk)

c. In welke gemeente volg je deze opleiding, en hoever is de school van je huis?

gemeente:

reisafstand: kilometer

6. Bij vraag 4 heb je iets aangekruist. Vul hiernaast $\mathrm{ja} \quad \rightarrow \quad$ gadoor met vraag 7 in of je ook nog betaald werk hebt. nee $\quad \rightarrow \quad$ ga door met vraag 13 (minstens 12 uur per week)

\section{Je huidige werk en beroep}

Heb je méér dan 1 baan, dan gelden de vragen 7 t/m 12 voor de baan waarin je de meeste uren werkt.

7 a. Is dit je eerste baan na het verlaten van de school?

b. Hoe ben je aan je huidige baan gekomen? Let op: maar één antwoord mogelijk!

c. Wanneer ben je in deze baan begonnen?

8 a. Betreft je huidige werk seizoenswerk of vakantiewerk?

b. In wat voor dienstverband werk je? ja

nee

geschreven of gebeld op een advertentie

via eerder betaald werk

via familie of vrienden/kennissen

de werkgever heeft mij gevraagd

via het arbeidsbureau

via een uitzendbureau

via vakantiewerk/bijbaantje

via stage/via de school

zelf aan de werkgever om werk gevraagd

via werkervaringsproject (bijv. Jeugdwerkgarantieplan)

anders, namelijk:

maand: jaar: 19

\section{seizoenswerk}

vakantiewerk

overig werk

leer-werkovereenkomst

(via het leerlingwezen/in-service opleiding) $\rightarrow$ ga door met vraag $8 \mathrm{c}$ loondienst

(ook werken via uitzendbureau)

$\rightarrow$ ga door met vraag $8 \mathrm{c}$ oproepkracht of nul-urencontract

$\rightarrow$ ga door met vraag $8 \mathrm{c}$ werkervaringsproject

$\rightarrow$ ga door met vraag $8 \mathrm{c}$

ik heb mijn eigen bedrijf

$\rightarrow$ ga door met vraag 9

werk mee in bedrijf van ouders/echtgenoot $\rightarrow$ ga door met vraag 9 
c. Wat voor aanstelling heb je?

9 a. Hoe heet het beroep of de functie die je hebt? (bijv. automonteur, metselaar, tuinder, receptioniste, verkoopster)

b. Wat zijn je voornaamste werkzaamheden? (bijv. verwarmingen installeren, schilderen, vee verzorgen, typen, kleding verkopen)

c. Op wat voor afdeling werk je? (bijv. administratie, montagehal, magazijn, receptie)

10a. Bij wat voor organisatie of bedrijf werk je? (bijv. machinefabriek, garagewerkplaats, kledingwinkel, ziekenhuis)

b. Hoeveel mensen werken er ongeveer? (het gaat om alle werknemers van het bedrijf in Nederland)

c. In welke plaats is het bedrijf gevestigd?

11a. Welk soort opleiding werd voor je huidige baan vereist?

b. Werd ook nog een speciale vakrichting vereist? (bijv. de richting bouw of bedrijfsadministratie)

12a. Hoeveel uur per week werk je in deze baan (volgens je contract)?

- tel overwerk niet mee

- ga uit van de laatste maand

b. Hoeveel verdien je in deze baan ongeveer bruto per maand?

- eventuele toeslagen of fooien meerekenen

- overwerk en vakantiegeld niet meetellen tijdelijk werk via een uitzendbureau

tijdelijk werk bij werkgever (1 jaar of korter)

tijdelijk werk bij werkgever (langer dan 1 jaar)

vaste baan of proeftijd voor een vaste baan minder dan 10

10 tot 50

50 tot 100

100 tot 500

500 tot 1000

1000 of meer

weet ik niet

lagere school was genoeg

een lagere beroepsopleiding (bijv. LTS, LHNO)

MAVO

leerlingwezen

HAVO/VWO

een middelbare beroepsopleiding (bijv. MTS, MDGO)

een hogere beroepsopleiding (bijv. HTS, HEAO)

ja, de richting die ik zelf heb gevolgd

ja, maar een andere richting

nee

\section{: .......... uur per week}

(wanneer je in het leerlingwezen zit, tel dan de uren op school niet mee)

bruto ongeveer: gulden per maand (ga uit van de laatste maand, zie eventueel je loonstrookje)
Op zoek naar (ander) werk

De vragen $13 \mathrm{t} / \mathrm{m} 24$ zijn voor iedereen bestemd 13a. Ben je actief op zoek naar een (andere) baan? (een betaalde baan voor minstens 12 uur per week)

b. Zo ja, hoe heb je de afgelopen 4 weken naar werk gezocht?

Let op: meerdere antwoorden mogelijk! $\square \mathrm{ja} \quad \rightarrow \quad$ ga door met vraag $13 \mathrm{~b}$

nee $\quad \rightarrow \quad$ gadoor met vraag 14

via advertenties

via familie of vrienden/kennissen

via het arbeidsbureau

via een uitzendbureau

zelf aan de werkgever om werk gevraagd

via school

anders, namelijk: 
c. Sta je als werkzoekende ingeschreven bij het arbeidsbureau?

d. Stel, je vindt nú een (andere) geschikte baan. Hoe snel kun je dan beginnen?

\section{ja}

nee

binnen 2 weken $\quad \rightarrow \quad$ ga door met vraag 14

binnen 3 maanden $\rightarrow \quad$ ga door met vraag $13 e$

pas na 3 maanden $\rightarrow \quad$ ga door met vraag $13 e$ e. Waarom kun je niet binnen 2 weken beginnen? vanwege opzegtermijn huidige baan

2. vanwege afronden van de huidige opleiding

vanwege afronden vrijwilligerswerk

vanwege regelen kinderopvang

vanwege vakantie of ziekte

6 vanwege een andere reden

\section{Aanvullende opleiding of cursus}

14a. Volg je nog een aanvullende opleiding of cursus? (geen hobby cursus; wel bijv. een bedrijfs$\begin{array}{ll}\square \text { ja } & \rightarrow \quad \text { ga door met vraag } 14 b \\ \square \text { nee } & \rightarrow \quad \text { ga door met vraag } 15\end{array}$ opleiding, vakcursus, applicatiecursus) Let op: vul hier niet de opleiding in die je misschien al bij vraag 3 of 6 hebt ingevuld!

b. Zo ja, welke opleiding of cursus? (hoe heet deze cursus en waar gaat hij over?)

c. Waarom volg je deze opleiding of cursus? het is nodig om bij te blijven in mijn huidige baan was nodig om mijn huidige baan te krijgen het is nodig om hogerop te komen ik wil in een ander soort baan gaan werken ik heb dan meer kans op werk andere reden, namelijk:

\section{De opleiding acheraf bezien}

15. Hoe vind je de aansluiting tussen je opleiding van vorig jaar en je huidige bezigheden?

(bijv. je werk of opleiding)

goed

voldoende

matig

slecht

16. Hieronder noemen we een aantal zaken.

Moet daar in de opleiding die je vorig jaar verlaten hebt méér of juist minder aandacht aan worden besteed?

a. Vakkennis/vaktheorie

b. Leren studeren

c. Vreemde talen (Engels, Duits e.d.)

d. Met cijfers werken (wiskunde, rekenen)

e. Informatica, automatisering

f. Praktijkoriëntatie of stage

g. Omgaan met apparatuur en materialen

h. Weten hoe een bedrijf georganiseerd is

i. Kennis van arbeidsvoorwaarden (CAO, wat te doen bij ontslag e.d.)

j. Organiseren/plannen

k. Zelfstandig werken

1. Commerciële kennis, verkooptechniek

$\mathrm{m}$. Correcte spelling/foutloos schrijven

n. Een verslag of rapport schrijven

o. Spreekvaardigheid

p. Samenwerken met collega's

q. Met mensen/klanten omgaan

r. Beroepskeuze/studiekeuze

s. Leren solliciteren

\begin{tabular}{|c|c|c|c|c|}
\hline 1 & 2 & 3 & 4 & 5 \\
\hline 1 & 2 & 3 & 4 & 5 \\
\hline 1 & 2 & 3 & 4 & 5 \\
\hline 1 & 2 & $\overline{3}$ & 4 & 5 \\
\hline 17 & 2 & 3 & 4 & 5 \\
\hline 1 & 2 & 3 & 4 & 5 \\
\hline 1 & 2 & 3 & 4 & 5 \\
\hline 1 & 2 & 3 & 4] & 5 \\
\hline 1 & 2 & 3 & $\sqrt[4]{4}$ & 5 \\
\hline 7 & 2 & 3 & 4 & 5 \\
\hline 1 & 2 & 3 & 4 & 5 \\
\hline 1 & 2 & 3 & 4 & 5 \\
\hline 1 & 2 & 3 & 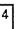 & 5 \\
\hline 1 & 2 & 3 & 4 & 5 \\
\hline 1 & 2 & 3 & 4 & 5 \\
\hline 1 & 2 & 3 & 4. & 5 \\
\hline 1 & 2 & 3 & 4] & 5 \\
\hline 1 & 2 & 3 & 4 & 5 \\
\hline 1 & 2 & 3 & 4 & 5 \\
\hline
\end{tabular}


17. Als je opnieuw voor de keuze stond, zou je deze opleiding dan opnieuw kiezen?

\section{Tot slot}

18. Wanneer ben je geboren?

19. Geslacht

20. Tot welke bevolkingsgroep hoor je?

21. Postcode huisadres (alléén de cijfers)

22. Wat is de hoogste opleiding van je ouders (of verzorgers)?

23. Je vroegere school wil graag weten wat leerlingen zijn gaan doen. Zo kan de school de leerlingen in de toekomst beter voorbereiden op een vervolgopleiding of een latere baan.

Vind je het goed wanneer aan je vroegere school wordt doorgegeven wat je nu doet?

24. Wanneer heb je deze vragenlijst ingevuld?

maand: .jaar: 19

man

vrouw

Nederlandse

Surinaamse

Antilliaanse/Arubaanse

Turkse

Marokkaanse

Anders, namelijk:

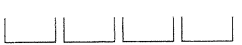

vader/verzorger

lagere school

lagere beroepsopleiding

MAVO/MULO

HAVO/MMS

VWO/Gymnasium/HBS

middelbare beroepsopleiding

hogere beroepsopleiding

universiteit

weet ik echt niet

ja, ik vind het goed

nee, ik heb hier bezwaar tegen moeder/verzorgster

lagere school

lagere beroepsopleiding

MAVO/MULO

HAVO/MMS

VWO/Gymnasium/HBS

middelbare beroepsopleiding

hogere beroepsopleiding

universiteit

weet ik echt niet

\section{Opmerkingen}

Ruimte voor opmerkingen over de school, het werk, de vragenlijst, e.d.

Hartelijk bedankt yoor het invullen.

Stuur de vragenlijst zo snel mogelijk op in de antwoordenvelop (een postzegel is niet nodig). 